\title{
: Corundum Deposits of Montana
}

By STEPHEN E. CLABAUGH

G E O L O G I C A L S U R V E Y B U L L E T I N 983

$A$ description of one of the three commercial deposits found in the United States

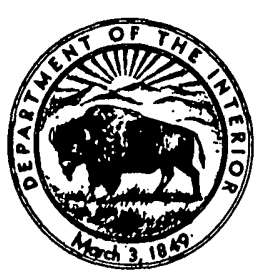

ORTON HALL LIBRARY

UNITED STATES GOVERNMENT PRINTING OFFICE, WASHINGTON : 1952 


$$
\begin{aligned}
& \text { QH. } 75 \\
& \text { Bg } \\
& \text { U0.983.985 } \\
& \text { UPY } 3
\end{aligned}
$$

UNITED STATES DEPARTMENT OF THE INTERIOR

Oscar L. Chapman, Secretary

GEOLOGICAL SURVEY

W. E. Wrather, Director

$\mathrm{x}$ Washington 25, D. C. 


\section{CONTENTS}

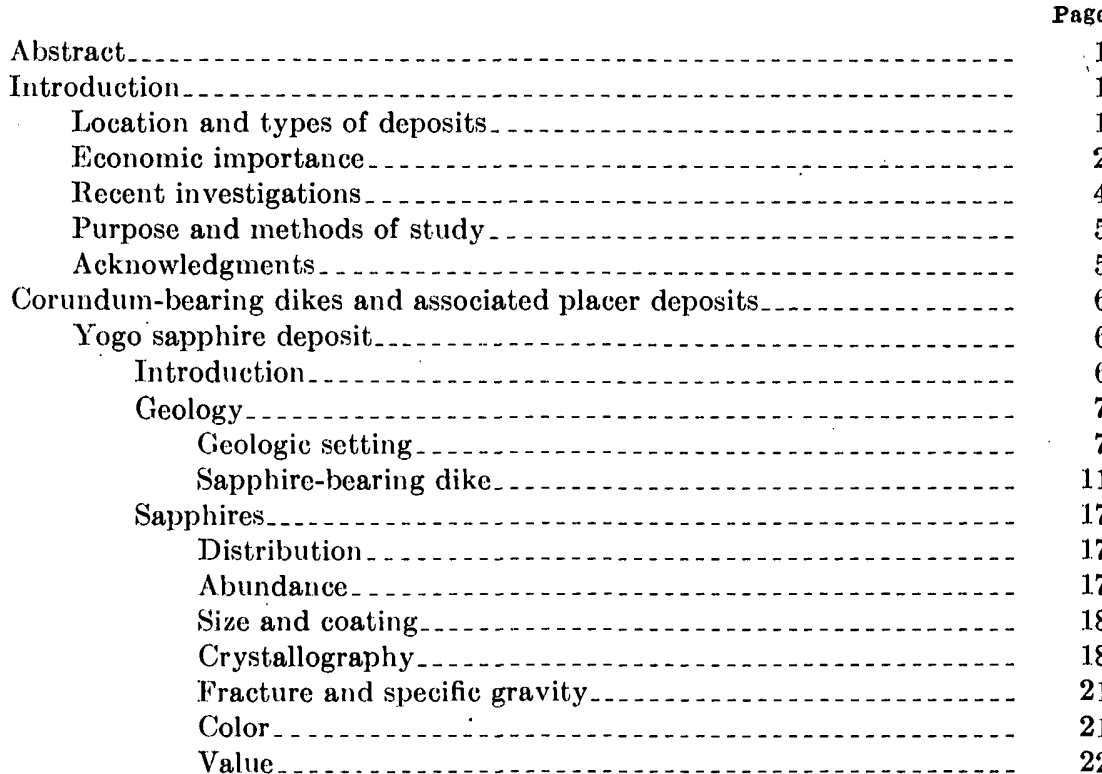

Economic development....

History .

Production methods . . . .

Production and reserves.................. 31

Missouri River sapphire deposits . . .

Location . . . .

Geology .

Sapphires

History and production . . . . . .

Roek Creek sapphire deposit_... 45

Location . . . . . . . .

Geology

Sapphires.

History and production $\ldots$

Dry Cottonwood Creek sapphire deposit_._.

Location . . .

Geology

Sapphires.

History and production.

Other sapphire occurrences . . . .

Quartz Gulch............. 54

Pole Creek

Browns Gulch........ 55

Chouteau County ........... 55

Origin of the corundum in dikes. 56 


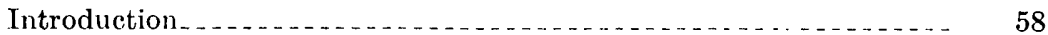

History and production $\ldots$

Geology . . . .

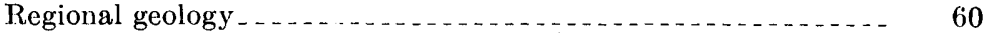

Metamorphic rocks.......................................... 61

General description . . . . . 61

Major types. .

Structure

Igneous rocks _...

Pegmatites...

Younger igneous rocks.

Metalliferous deposits . .

Description of the corundum deposits _...

Elk Creek deposit . .

Bozeman deposit

Bear Trap deposit. ...

Other occurrences.

Economic importance of the deposits .

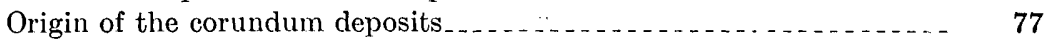

A genetic classification of corundum deposits $\ldots \ldots \ldots$

Examples of corundum deposits in other regions ............ 78

Origin of the deposits in southwestern Montana............ 82

Hypothesis of igneous origin . . .

Hypothesis of hydrothermal origin ................. 88

Hypothesis of origin by metamorphism and metasomatism of alumina-rich sedimentary rocks . . . .

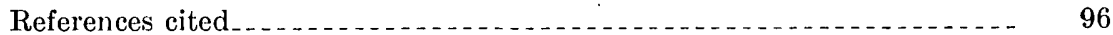

Index $\ldots$

\section{ILLUSTRATIONS}

Plate 1. Map of the Yogo sapphire deposit, Judith Basin County, Mont. . . . . . . . . . . . . . . . . . . . . . . . . . . In pocket

2. Geologic map of the corundum deposits of Gallatin and Madison Counties, Montana_................... In pocket

3. Outcrop map and longitudinal projection of the Elk Creek corundum deposit . ...............................

4. Mine workings and sections of the Elk Creek corundum deposit_...

5. Outcrop map of the Bozeman corundum deposit......... In pocket

6. Outcrop map of the Bear Trap corundum deposit_....... In pocket

Figure 1. Index map showing location of Montana corundum deposits... $\quad 3$

2. Property map of the New Mine Sapphire Syndicate......... 8

3. View eastward along the old open-cuts of the British sapphire

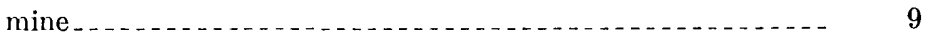

4. View westward into the mouth of Kelly Gulch ......... 10

5. East wall of Yogo Gulch.................... 11

6. Yogo sapphire crystals _.......................... 20 
Figure 7. Longitudinal section showing approximate extent of underground workings in the Yogo sapphire deposit.

8. Sapphire crystals from Missouri River and Rock Creek deposits_

9. Map showing location of the Rock Creek sapphire deposit and placer claims of the American Gem Mining Syndicate...... -

10. Coarsely crystalline corundum-bearing gneiss from the Elk Creek corundum deposit.................................

11. Corundum-bearing gneiss showing an abundance of coarsely crystalline aggregates of corundum and feldspar . ..........

12. Photomicrograph showing platy, skeletal crystals of corundum.

13. Photomicrograph of corundum crystals transecting subradial sillimanite . . . . . . . . . . . . . . . . . . . . . . . . 


\title{
GORUNDUM DEPOSITS OF MONTANA
}

\author{
By Stephen E. Chabaugh
}

\begin{abstract}
ABSTRAC'
Between $\$ 3,000,000$ and $\$ 5,000,000$ worth of corundum has been produced in Montana. The corundum deposits include occurrences of sapphires in dikes, placer deposits of gem and industrial sapphires, and deposits of abrasive corundum in metamorphic rocks. Corundum-bearing dikes are associated with placer sapphires at French Bar on the Missouri River and at the Yogo deposit, and similar igneous rocks are assumed to have supplied the sapphires found in other: placer deposits of the region. The sapphires in the Yogo dike are interpreted as a product of direct crystallization from the magma, possibly as a result of reaction between the magma and kyanite-bearing inclusions.

Three deposits of abrasive corundum in the vicinity of Bozeman, Mont., have been explored and partly developed by prospectors and mining companies, and by the United States Bureau of Mines. The largest of the deposits has yielded only a few hundred tons of corundum-bearing rock, and the known reserves of: the three deposits amount to no more than a few thousand tons of rock containing 10 percent or less corundum. The corundum-bearing rock occurs as lenticular to tabular bodies in metamorphosed pre-Cambrian sedimentary rocks. Sillimanite, feldspars, muscovite, biotite, and rutile are the chief minerals associated with the corundum. A thin border zone of vermiculite-rich gneiss commonly separates the corundum-bearing rocks from the enclosing hornblende gneiss. The texture of the rock is varied, ranging from fine-grained and schistose to very coarsely crystalline, resembling pegmatite. The origin of the abrasive corundum is not so easily deciphered as that of the gem and industrial sapphires which occur in unmistakable igneous dikes. The following three modes of origin are considered for the abrasive corundum deposits: 1 ) as sills of corundum-bearing syenite or pegmatite, 2) as hydrothermal veins, and 3) as metamorphosed alumina-rich sedimentary rocks. Metamorphic origin involving some metasomatism is favored as the hypothesis that best accounts for the form, distribution, and structural relations of the deposits, their variation in composition and texture, and the mineral relations.
\end{abstract}

\section{INTRODUCTION}

\section{LOCATION AND TYPES OF DEPOSITS}

Nearly all commercial production of corundum in the United States has come from three regions. One includes a belt of deposits in North Carolina and Georgia, another consists of scattered deposits in western Montana, and the third is represented by deposits of emery in Massa- 
chusetts and New York. Other occurrences have yielded insignificant quantities of corundum. This study is concerned only with the Montana deposits. Location of the more important corundum deposits of Montana is shown on the index map, figure 1.

The Montana corundum deposits are of several genetic types, and the corundum itself ranges from dull, abrasive material to gem sapphires of excellent quality. At the Yogo sapphire deposit, gem stones were first found in placer deposits and later produced in quantity from an altered igneous dike. The Yogo deposit also yielded large numbers of small sapphires which were sold for watch jewels, instrument bearings, and similar industrial uses. Industrial sapphires and a few gem sapphires have been recovered as a byproduct of placer-gold operations along the Missouri River near Canyon Ferry, northeast of Helena. Sapphire-bearing dikes, the probable source of the placer sapphires, have been observed in the vicinity of the Missouri River deposits. Industrial sapphires similar to those from the Canyon Ferry locality have been produced from placers on tributaries of Rock Creek southwest of Philipsburg, but their source has not been located. Industrial sapphires are found also in placer deposits southeast of Deer Lodge along Dry Cottonwood Creek, southwest of Bozeman in Pole Creek, and elsewhere in the region. Deposits of abrasive corundum occur as lenticular to tabular bodies of corundum-bearing gneiss in the metamorphic rocks southwest of Bozeman.

Gem and industrial sapphires found in Montana are probably all of igneous origin. The lenses of corundum-bearing gneiss in metamorphic rocks are of disputed origin. They have been called syenite and pegmatite, but their igneous character is not established. Hypotheses of hydrothermal origin and of origin by metamorphism of aluminous sedimentary rocks are also presented.

\section{ECONOMIC IMPORTANCE}

Known deposits of corundum in this country are sufficient to supply only a small fraction of the requirements of American industries. The principal foreign source in recent years is South Africa. Emery is imported chiefly from the Grecian islands and Turkey. The manufacture of synthetic corundum for instrument bearings and numerous other uses has become an important industry in this country within the last 10 years.

Between $\$ 3,000,000$ and $\$ 5,000,000$ worth of corundum has been produced in Montana. Before mining was discontinued in 1929, the Yogo deposit yielded sapphires, chiefly gem material, valued at about $\$ 2,500,000$ in the rough. Cut stones from the Yogo deposit probably have a present value of more than $\$ 25,000,000$. Industrial sapphire production from the placer deposits has been sporadic. Annual pro- 


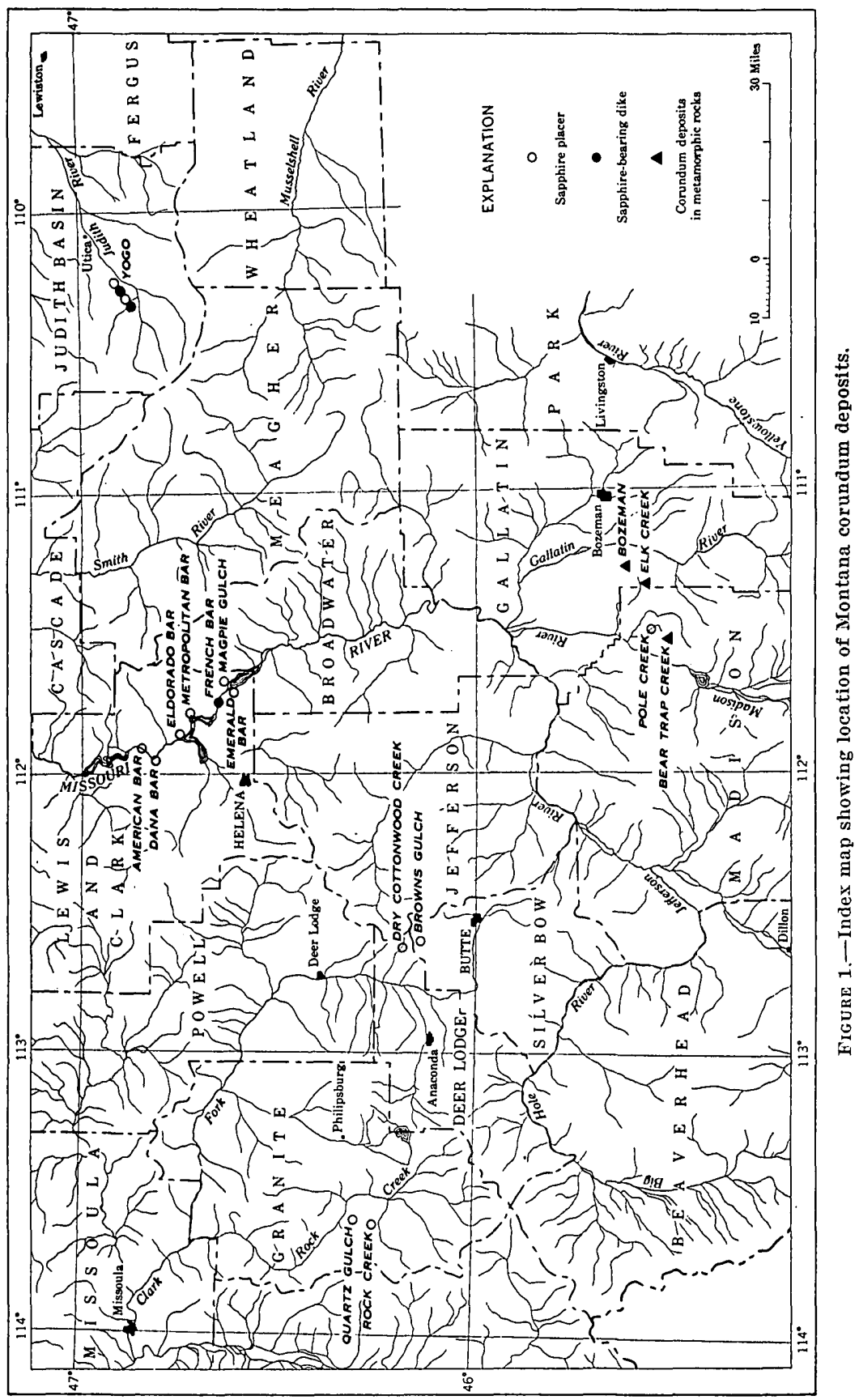


duction was valued at $\$ 20,000$ to $\$ 50,000$ during the period $1936-43$, but periods of inactivity preceded and followed those years. Synthetic corundum has now largely displaced natural sapphire for industrial use. About 350 tons of corundum-bearing rock was produced from the Elk Creek deposit by the Montana Corundum Co. during 1901-3, but there has been no other production from the deposits in metamorphic rocks.

Reserves of gem-bearing dike rock in the Yogo deposit are very large. Although the amount of unworked sapphire-bearing placer ground in the Missouri River, Rock Creek, Cottonwood Creek, and other localities is unknown, it is doubtful that large-scale operations will again be conducted for the recovery of placer sapphires alone. Some production of sapphires from the Missouri River deposits as in byproduct of gold dredging may be expected. Exploration of the deposits of abrasive corundum in Gallatin and Madison Counties during the recent war revealed a lack of significant reserves there.

\section{RECENT INVESTIGATIONS}

Increased industrial demands and restricted foreign trade during the war caused shortages of corundum to develop, particularly in the part of the grinding-wheel industry that requires coarse grain sizes. Development of domestic sources of corundum was considered desirable, and a number of deposits were investigated by the U. S. Geological Survey and the U. S. Bureau of Mines. In Montana, attention was centered on deposits of corundum in the metamorphic rocks of Gallatin and Madison Counties which were believed to be potential sources of relatively large quantities of coarsely crystalline corundum.

The Elk Creek corundum deposit was examined briefly in January 1943 by H. L. James and W. R. Jones of the U. S. Geological Survey, and again in August 1943 by S. K. Neuschel and M. D. Crittenden, Jr. In January 1943 James and Jones visited also the gold dredge at Eldorado Bar on the Missouri River where industrial sapphires were being recovered. The U. S. Bureau of Mines began exploration of the Elk Creek deposit in October 1943 and later explored the Bozeman and Bear Trap deposits. Neuschel and F. C. Armstrong of the Geological Survey prepared a plane-table map of the Elk Creek deposit in November 1943, and examined the Bozeman deposit. Armstrong and Crittendon visited the Elk Creek and Bozeman deposits in 1944, and mapped the more important underground workings. After the Bureau of Mines began exploration of the Bear Trap corundum deposit, Armstrong examined that area in December 1944, and he mapped the geology of the Bureau of Mines trenches at the Bozeman deposit while exploratory work was in progress there in January 1945. In late March and early April 1945, Armstrong and G. M. Sowers mapped 
new underground workings at the Elk Creek deposit. In the summer of 1945 the writer prepared plane-table maps of the Bozeman and Bear Trap deposits and extended the map of the Elk Creek deposit. During the summer of 1946 he mapped about 80 square miles of the region adjoining the Elk Creek, Bozeman, and Bear Trap deposits, prepared a plane-table map of the Yogo sapphire deposit, and briefly examined the placer sapphire deposits on Rock Creek and along the Missouri River.

\section{PURPOSE AND METHODS OF STUDY}

Geologists of the U. S. Geological Survey examined and mapped the deposits of abrasive corundum southwest of Bozeman, Mont., during the period 1943-45 in order to determine the potential reserves of the region and the feasibility of corundum production. Geologic mapping was intermittent, preceding, accompanying, and following exploratory work of the U.S. Bureau of Mines and Industrial Minerals Corporation. A report dealing with the limited economic possibilities of the deposits has been prepared by F. C. Armstrong and the writer (Clabaugh and Armstrong, 1951).

In 1946 the writer was encouraged to complete a study of Montana corundum deposits with a view to economic considerations but with emphasis on petrologic and mineralogic problems. The occurrences are unusual, and their origin has aroused much speculation.

Study of the corundum deposits in metamorphic rocks in Gallatin and Madison Counties has included : regional mapping on aerial photographs of an area of about 80 square miles adjacent to the deposits; detailed plane-table mapping on a scale of 100 feet to the inch, or 200 feet to the inch, of the three deposits; geologic mapping of mine workings, bulldozer trenches, and prospect pits; analysis of Bureau of Mines sample data; and microscopic study of the rocks associated with the deposits. Partial chemical analyses of four samples from one of the deposits and also a minor amount of X-ray study of minerals have been included.

A plane-table map of the Yogo sapphire deposit was prepared on a scale of 500 feet to the inch. Samples for petrographic study and chemical analysis were collected from the Yogo deposit, from deposits along the Missouri River, and those on Rock Creek. Additional data were obtained from operators and from the literature.

\section{ACKNOWLEDGMENTS}

The work was done as part of the Department of the Interior program for the development of the Missouri River basin. F. C. Armstrong, S. K. Neuschel, and M. D. Crittenden, Jr., contributed a large part of the early field work and Armstrong collaborated in preparation 
of a preliminary report (Clabaugh and Armstrong, 1951). Many persons contributed valuable assistance and information in the field. Among them are Ray Woodriff of Montana State College, Charles 'T. Gadsden and Mrs. Gadsden of the New Mine Sapphire Syndicate, Owen D. Perry of Perry-Schroeder Mining Co., Jesse Green of Bozeman, Mont., Joe Yob of Philipsburg, Mont., R. D. O'Brien and J. B. Hopkins of the U. S. Bureau of Mines. C. S. Hurlbut, Jr., of Harvard University visited the writer in the field, and E. S. Larsen, Jr., supervised much of the work in the laboratory at Harvard. Hurlbut and Larsen have aided with many helpful suggestions and by critical reading of the manuscript.

The writer's wife, Patricia S. Clabaugh, took an active part in the field work, particularly in the preparation of plane-table maps of the Bozeman, Bear Trap, and Yogo deposits.

\section{CORUNDUM-BEARING DIKES AND ASSOCIATED PIACER DEPOSITS}

Corundum-bearing dikes of indisputably igneous character have been observed in Montana at the Yogo sapphire deposit and near Canyon Ferry on the Missouri River (fig. 1). The first has yielded a large quantity of transparent gem sapphires of blue color, most of which were recovered directly from the dike rock, a few from adjacent residual and placer deposits. At the second locality transparent to translucent sapphires of various pale colors are recovered from gold, placers, and they have been observed in place in one or more small dikes. A few of these sapphires have been cut as gems, but most of them were sold for industrial use. Similar sapphires were produced from placer deposits on Rock Creek, and they occur also at other localities at which source dikes have not been located.

\section{YOGO SAPPHIRE DEPOSIT}

\section{INTRODUCTION}

The Yogo sapphire deposit is the most important gem locality in the United States. Cut sapphires of excellent quality, valued possibly at as much as $\$ 20,000,000$ to $\$ 30,000,000$ have been produced from the deposit, and reserves of sapphire-bearing material are probably adequate to supply several times the quantity mined. Most of the mining was done by a British syndicate which suspended, operations in 1929 . All rights to the deposit are still held by the syndicate.

The deposit is not well known, and it has never received detailed study. A few descriptions have been published, most of them during the period 1895-1900. The locality is visited occasionally by a few tourists, mineralogists, geologists, and members of the mining profession. Many of these persons have been guests of Charles T. Gadsden, local manager of the New Mine Sapphire Syndicate, and Mrs. 
Gadsden, who have resided at the property since about 1900. The writer is particularly indebted to the Gadsdens, both for their hospitality on numerous occasions, and for the wealth of information supplied by Mr. Gadsden and incorporated in the pages that follow.

The Yogo sapphire deposit is located in Judith Basin County, 10 to 15 miles southwest of the small town of Utica, and approximately 45 miles southwest of Lewistown. The British mine may be reached over 13 miles of improved dirt road from Utica. The abandoned American mine on Yogo Creek is no longer accessible by road. The sapphirebearing dike has been traced for a distance of more than 4 miles in an essentially east-west direction. Lode claims, placer claims, and agritultural lands owned by the New Mine Sapphire Syndicate are shown on the property map, figure 2.

The sapphire-bearing dike occurs at the northeastern margin of a rough, mountainous region, at an elevation of about 5,000 feet. To the east and north are broad valleys, open grassland, farms, and low hills. About 10 to 15 miles west and south of the deposit, the peaks along the crest of the Little Belt Mountains rise to elevations of 8,000 to 9,000 feet. The region to the northeast is semiarid, suited to cattle raising and wheat production by dry farming methods. The mountainous region to the southwest is sparsely inhabited. A few ranches are located in the valleys, and there is sporadic activity in some of the old mining camps. Growths of timber cover most of the mountain slopes.

Along the eastern two-thirds of its extent the sapphire-bearing dike is in an open, rolling, grassland (fig. 3) with occasional forested valleys and low hills, increasing in elevation westward to the heights above Yogo canyon. The western part of the dike is in the rough canyons of Yogo and Kelly Gulches, where limestone cliffs rise abruptly several hundred feet above the canyon floor (figs. 4 and 5). The topography is shown in detail on the plane-table map of the deposit, plate 1.

\section{GEOLOGY}

The geology of the Yogo sapphire deposit is exceedingly simple. A nearly vertical sapphire-bearing igneous dike cuts through gently dipping limestone. Corundum has not been found in other igneous rocks of the region. Surface exposures of the dike rock are very poor, for it weathers more readily than the adjacent limestone.

\section{GEOLOGIC SETTING}

Sedimentary rocks exposed in the vicinity of the sapphire deposit are massive limestones of the upper part of the Madison limestone of Mississippian age and varicolored shales of the Amsden formation of Mississippian and Pennsylvanian age. At its eastern end the sapphire-bearing dike cuts shaly rocks overlying the Madison limestone; 


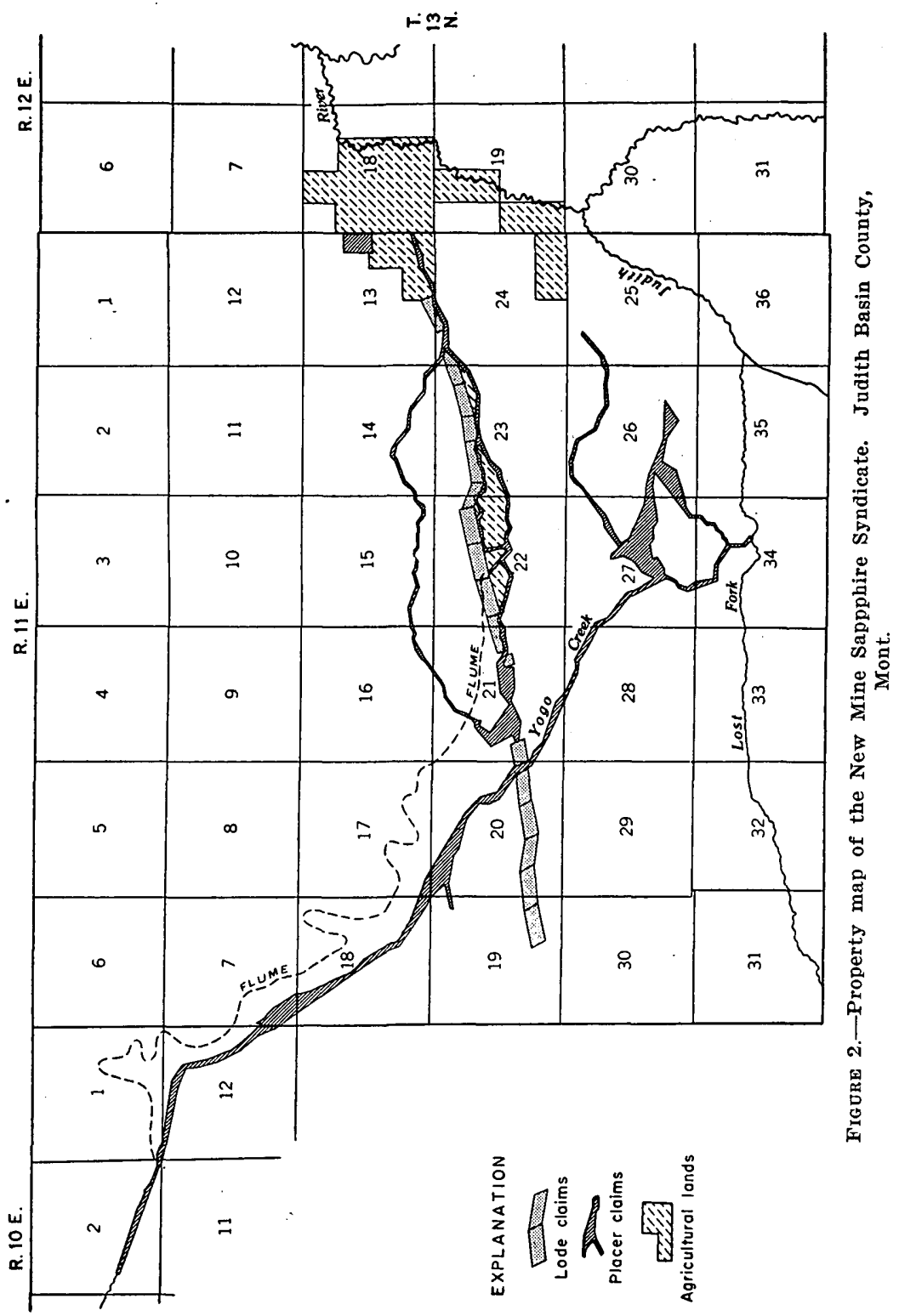




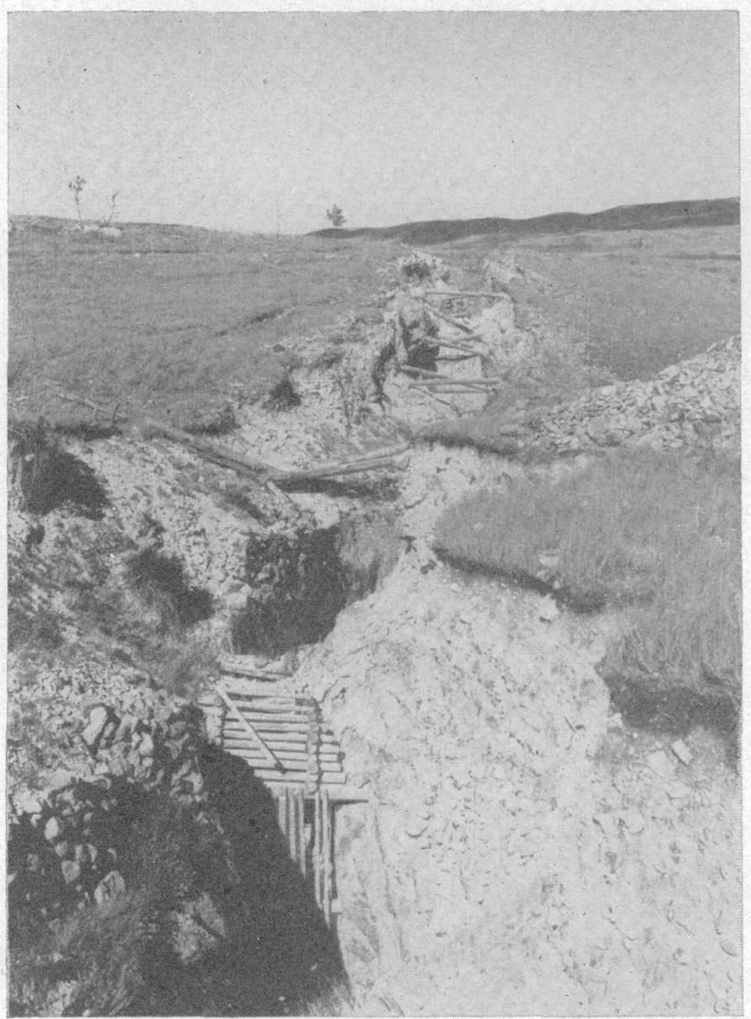

Figure 3.-View eastward along the old open-cuts of the British sapphire mine, Judith Basin County, Mont.

throughout the remainder of its surface extent the dike is in contact with limestone. The Madison limestone is 1,800 feet thick in this area according to Weed $(1899$, p. 9$)$. The upper part of the formation, well exposed along Yogo Gulch (figs. 4 and 5), consists of massive limestone with indistinct bedding and infrequent shaly layers. The lower and middle parts of the formation are relatively thin bedded and contain more numerous beds of shale or clay. Older sedimentary rocks are exposed west and south of the sapphire deposits. They include dark limestone and shale of Devonian age and limestones, shales, conglomerates, and quartzites of Ordovician and Cambrian age. The Cambrian sedimentary rocks rest on argillites, quartzites, and impure limestones of the pre-Cambrian Belt series and these, in turn, lie on older gneisses and schists. Younger sedimentary rocks crop out northeast of the sapphire deposit in the broad basin through which the Judith River flows.

A wide variety of igneous rocks has been described from the region immediately west of the sapphire deposit in the Little Belt Mountains. Lamprophyric rocks are common in small dikes and sills, and the 


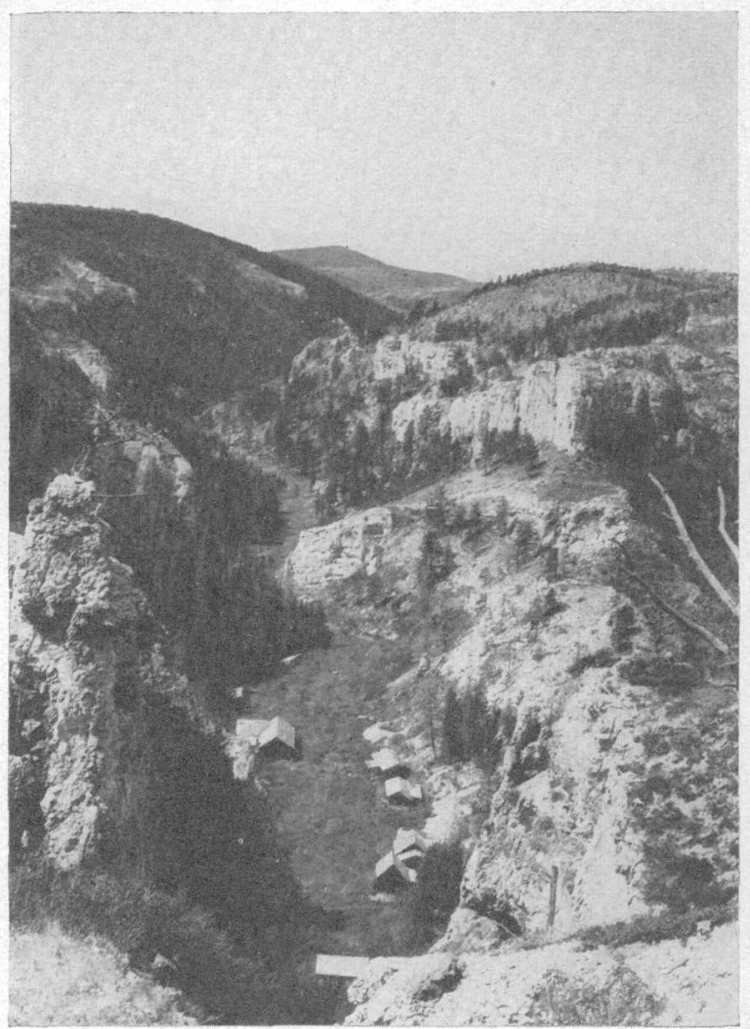

Figure 4.-View westward into the mouth of Kelly Gulch from the crest of the east wall of Yogo Gulch. Dumps of old mine workings may be seen along the northern margin of the valley floor behind the row of deserted houses. Judith Basin County, Mont.

sapphire-bearing dike probably belongs to this group. According to Pirsson (1900, p. 553):

It has evidently a close affinity with the minettes and shonkinite of the region, and is clearly of the same magma. It has the same richness in biotite and pyroxene as these, but differs in the feldspathic component. Yogo Peak, with its shonkinite, is but a small number of miles distant from the locality.

Most of the igneous rocks in the area are believed to be of Teritiary age. Direct evidence indicates only that the sapphire-bearing dike is post-Pennsylvanian.

A second dike, evidently similar in mineralogy to the one in which gems are found, occurs about 600 feet north of the sapphire dike. No fresh rock is exposed at the surface. Partly altered fragments from prospect pits consist chiefly of augite and biotite. Weed (1900, p. 459) states that "The rock and its debris show no sapphires, although many cart loads of the dirt have been washed from different points along the outcrop:" Sapphires have not been reported from any other rocks of the region. 


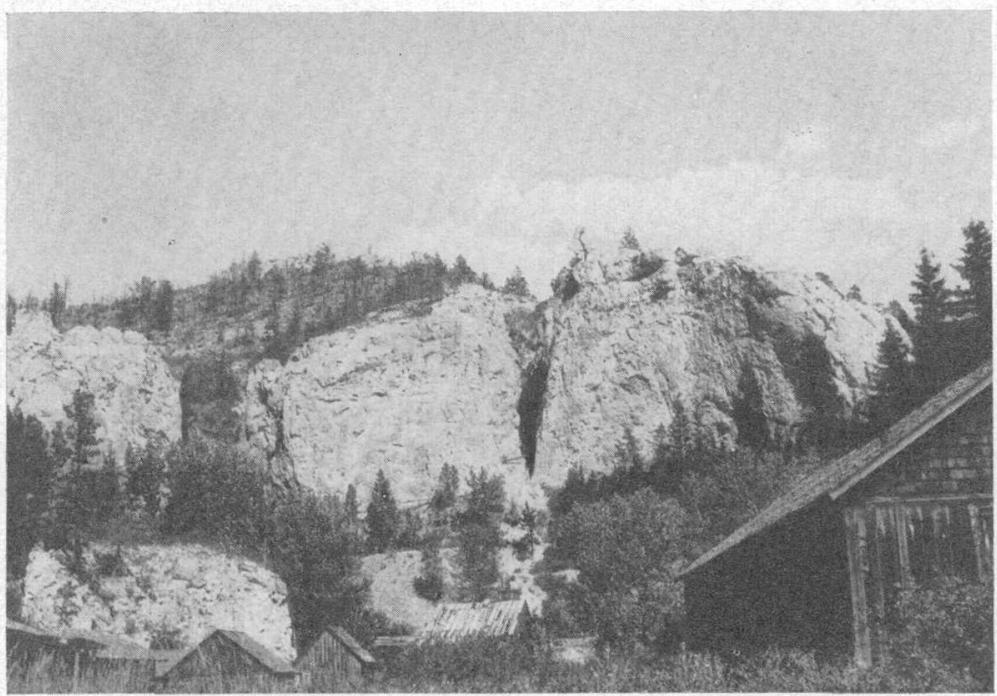

Figure 5.- - East wall of Yogo Gulch as seen from the valley of Kelly Gulch. The cleft in the limestone cliff marks the fracture zone along which the sapphire-bearing dike was emplaced. Judith Basin County, Mont.

\section{SAPPHIRE-BEARING DIKE}

Lode and placer claims were located along the length of the dike as far as it could be traced, a distance of almost 5 miles. (See fig. 2.) Exposures at both ends were chiefly in small prospect pits which have since caved. The central part of the dike and all major workings are shown on the plane-table map, plate 1 . The average strike of the dike is about $\mathrm{S}$. $75^{\circ} \mathrm{W}$., but as the map shows, it does not follow a straight course. The dip is nearly vertical as indicated by the walls of the old surface workings. (See fig. 3.) C. T. Gadsden reports, in an oral communication, that the average width of the dike in the mine workings was approximately 8 feet and the maximum width more than 20 feet.

The dike rock weathers readily under surface conditions, so that there are no natural exposures of the igneous rock. Weed $(1899$, p. 9$)$ observed that "the course of the fissure can be traced by a grassy depression in the bare limestone surface, which is dotted with badger and gopher heapings. One of the heapings yielded several hundred carats of gems and was the direct cause of the discovery of the dike." Near the surface the dike rock is altered to a soft, yellow to gray clay surrounding innumerable rough boulders and fragments of yellowand brown-stained limestone. At greater depth, 5 to 50 feet below the surface, the altered dike rock consists partly of a greenish-gray, friable rock and partly of blue clay, with residual masses of hard, relatively unaltered igneous rock. Locally the dike is dominantly limestone breccia cemented by a subordinate amount of igneous rock, 
and at no place is the dike rock free of small inclusions of limestone and other rocks.

The combination of soft, altered dike rock and residual boulders of hard, nearly fresh igneous rock was found at all depths in the underground workings. The proportion of unaltered to altered rock 250 to 300 feet below the surface is not notably different from that near the surface, according to Gadsden. The alteration may have been produced in part by hydrothermal solutions, or it may have been accomplished almost exclusively by underground water of meteoric origin. 'The water table lies far' below the surface in the underlying Madison limestone, certainly well below the lowest mine workings, which are relatively dry.

No major faults cut the dike, which is relatively uniform in attitude throughout its known length. Locally the dike is choked with limestone fragments and is narrow or absent; at one point it jogs abruptly as if displaced about 50 feet by a transverse fault, but Gadsden states that the dike is continuous below the surface at this point. Another irregularity in the trend of the dike occurs between the main shaft and the limestone cliff at the American mine on the east side of Yogo Creek. Sterrett (1908, p. 820) described the dike at this locality as follows:

The outcrop of the dike in the foot of the canyon wall was not at first located, since it was rather indefinite and was partly covered with large blocks of talus. A crosscut tunnel was driven from the north side until the dike was located, and from this the main drift was carried eastward on the one side, and the dike traced to its outcrop in the canyon wall on the other. A large body of pay rock, apparently over 45 feet wide, was located by the cross cut and drift. Though the relation of this ore body to the dike was not definitely known at the time of the writer's visit, it seemed to cut across the regular dike with a dip of about $40^{\circ}$ to the east. No definite hanging wall had been located, though the pay streak was about 12 feet thick from the footwall. This body of ore had been brecciated and the broken masses squeezed into slickensided lenses.

In most exposures of the dike walls, corresponding limestone beds lie opposite each other without appreciable offset, although commonly tilted at slightly different angles. In a few places a vertical offset of a foot or less could be determined. The walls are well exposed in the surface cuts, even in cuts of considerable depth that have stood open for as much as 50 years. (See fig. 3.) Adjacent to the altered dike the limestone is fractured and discolored with yellow and brown stains, but no contact metamorphic effects were noted.

Description of the igneous rock is based on examination of boulders and fragments of relatively fresh, hard material discarded during mining operations. The most readily apparent characteristics of the rock are its dull-gray or greenish-gray color, fine texture except for scattered flakes of dark-brown biotite several millimeters in diameter, and a spotted appearance due to the abundance of inclusions. 
The inclusions are chiefly white limestone fragments, and they range in size from minute grains to boulders. Small inclusions, less than 1 centimeter long, are especially abundant in some parts of the rock. When exposed to the weather for a number of years the firm dike rock gradually breaks down to gray-green sand and clay filled with innumerable small flecks of biotite.

Microscopic examination of the rock shows that it is made up chiefly of pyroxene and biotite in grains that average less than one-fourth millimeter in maximum diameter. The larger biotite flakes, which are noted in hand specimens, make up less than one percent of the volume of the rock. In his description of the rock Pirsson (1897, pp. 419-420) wrote as follows:

The biotite is strongly pleochroic, varying between an almost colorless and a strong, clear, brown tint. It occurs in ragged masses, rarely showing crystal outline, and it contains a large amount of small apatite crystals. The pyroxene is of a pale green tint with the habit of diopside and is flled with many inclusions, now altered but probably originally of glass; in some crystals these inclusions are so abundant as to render the mineral quite spongy. The grains sometimes show crystal form but are mostly anhedral and vary in size, though the evidence is not sufficient to show two distinct generations.

These two minerals lie closely crowded together and no feldspars are seen in the rock. The interstices between them consist of a small amount of a clouded, brownish, kaolin-like aggregate, which appears to represent some former feldspathoid component, possibly leucite, perhaps analcite. The rock appears to have its closest affinities in the monchiquite group, of which it may be considered a basic, somewhat altered type. The abundance of biotite shows its relation to the minettes, but the rock is much richer in the ferromagnesian components and lacks the feldspar of the minettes.

In a similar description published at a later date Pirsson (1900, p. 553) classed the rock as an altered analcime basalt.

A chemical analysis of the sapphire-bearing dike rock was prepared in 1950 by Eileen K. Oslund of the Rock Analysis Laboratory, University of Minnesota. The analysis and the calculated normative mineral composition, both calculated as percent by weight, are as follows :

\section{Chemical analysis of sapphire Jbearing dike rock}

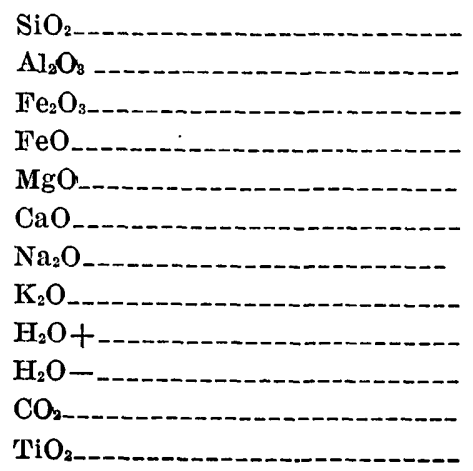

38. 54

11. 73

3. 33

3.58

11. 30

15. 60

1. 00

2. 32

2. 33

1. 34

5. 56

1. 06
0.00

$\mathrm{P}_{2} \mathrm{O}_{5}$

$\mathrm{S}$

$\mathrm{Cr}_{2} \mathrm{O}_{3}$

$\mathrm{MnO}$

$\mathrm{SrO}$

$\mathrm{BaO}$

99.90

Less $\mathrm{O}$ equivalent to $\mathrm{S}$ and $\mathrm{Cl}_{---} \quad .09$

99. 81 
Calculation of normative minerals

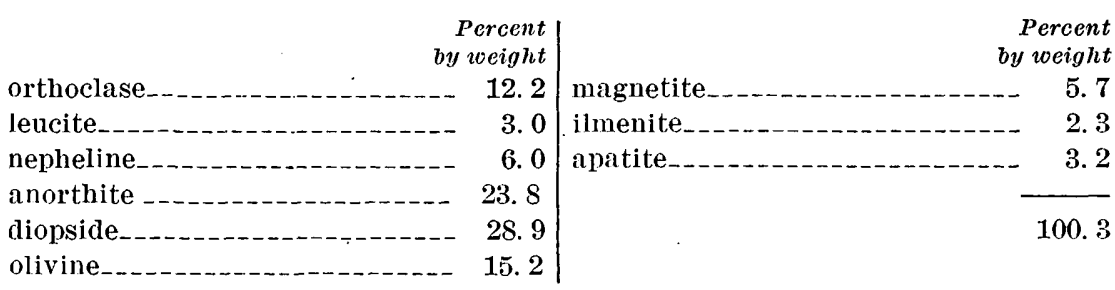

The norm was calculated after deducting from the analysis the $\mathrm{CO}_{2}$, $\mathrm{H}_{2} \mathrm{O}, \mathrm{Cl}, \mathrm{S}$, and 3.5 percent $\mathrm{CaO}$. The $\mathrm{CO}_{2}$ was assumed to be present in secondary calcite and in limestone inclusions, but only half of the $\mathrm{UaO}$ equivalent to $\mathrm{CO}_{2}$ in the calcite was assumed to be of foreign origin; the other half possibly was derived from calcium-bearing minerals in the original igneous rock.

The calculated mineral content of the rock does not approximate the actual mineralogic composition, which is approximately as follows (excluding calcite and dolomite) :

$\begin{array}{r}\text { Percent } \\ \text { by volume }\end{array}$
Pyroxene_- Analcime and matrix $\begin{array}{r}\text { Percent } \\ \text { by volume }\end{array}$

Among other minerals are the following: apatite, magnetite, zircon, hematite, feldspar, spinel, aegirite-diopside, and fibrous zeolites. Calcite and dolomite are abundant in the rock, chiefly in limestone fragments, veinlets, cavity fillings, and small irregular stringers replacing pyroxene.

In accordance with the Johannsen quantitative mineralogical classification of igneous rocks (Johannsen, 1939, pp. 141-161) the Yogo dike rock may be assigned the number 3125 . Typical monchiquite and analcime basalt also fall in Johannsen's family 25 (Johannsen, 1938, pp. 310-395), but both contain olivine and a smaller portion of the dark minerals than the Yogo rock. A number of similar rocks have been described and given varietal names; the most nearly equivalent are certain basic dikes designated ouachitite by Kemp (1891, pp. 392-398), which, however, are markedly porphyritic.

The diopside of the sapphire-bearing dike occurs in crystals of varied size. Most of the crystals are between 0.1 and 0.4 millimeter in diameter, but larger grains are common and a few reach a length of more than 5 millimeters. Some of the larger crystals occur as irregular grains in clusters as much as 1 centimeter in diameter, but most of the crystals tend to be euhedral except where crowded together. They are approximately equidimensional and colorless or very pale green in thin section. The outer parts of the crystals show moderate zoning with distinctly more yellow-green color at the 
margins. Many grains are partly replaced by calcite or dolomite in small irregular stringers and patches, and swarms of minute inclusions are common. The optical properties of the pyroxene from a crushed fragment of the rock are as follows:

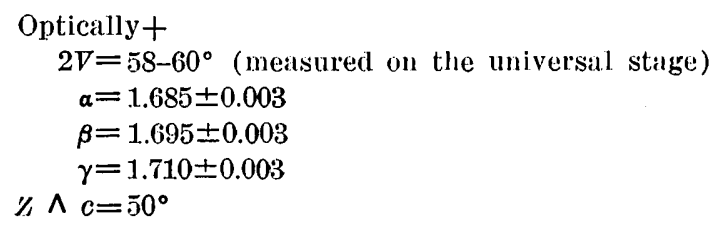

Pyroxene from one of the larger aggregates of irregular grains i... found to have slightly lower indices of refraction,

$$
\begin{aligned}
& \alpha=1.675 \pm 0.003 \\
& \beta=1.685 \pm 0.003 \\
& \gamma=1.705 \pm 0.003
\end{aligned}
$$

The optical properties indicate that the pyroxene is dominantly diopside (about 70 to 85 percent by weight) and hedenbergite, or more likely diopside, hedenbergite, and aegirite, with the aegirite content higher in the marginal zones, adjacent to interstitial analcime. The extinction angle $(Z \wedge c)$ of the marginal zone is about $60^{\circ}$. A few small elongate bright-green crystals of aegirite-diopside occur: with the larger aggregates of analcime.

Most of the biotite occurs in small grains that average 0.15 to 0.20 millimeter in length and 0.05 to 0.10 millimeter in width. Larger flakes are scattered sparsely through the rock. The smaller grains are strongly pleochroic in thin section, with $X=$ nearly colorless, $Y$ and $Z=$ reddish brown to greenish brown. The larger crystals show a distinct inner zone with less pronounced pleochroism; $X=$ colorless, $Y$ and $Z=$ pale yellowish brown. The refractive indices of the biotite are somewhat varied; average values are approximately as follows:

$$
\begin{gathered}
a=1.58 \\
\beta \mathcal{\&} \gamma=1.61-1.62
\end{gathered}
$$

Optic angle small and slightly varied.

The biotite probably contains slightly more magnesia than iron oxides.

The material listed as analcime and matrix is the interstitial "clouded, brownish, kaolin-like aggregate, which appears to represent some former feldspathoid component" noted by Pirsson (1897, - p. 420). Part of the interstitial material is clear to slightly clouded analcime, which occurs also in a few larger, rounded and irregular grains or clusters and at the margins of some calcite aggregates. The refractive index of the analcime is about 1.485 to 1.490 , and the larger grains exhibit faint, patchy anisotropism. Calcite is abundant in 
the interstitial material and locally cancrinite and fine-grained aggregates of fibrous zeolite(?) are present. But about half of the interstitial material is an extremely fine-grained, clouded aggregate of undetermined composition.

Magnetite is scattered through the rock in innumerable small equidimensional crystals that average about 0.05 millimeter in diameter. They are most abundant in the fine-grained mineral aggregates and interstitial material. Small crystals of apatite are common, especially as inclusions in biotite. Apatite is partly decomposed to soluble phosphates in the altered dike rock, and tailings from the sapphire operations promoted luxuriant growth of grain and vegetables when spread over farmland below the British mine.

Weed (1900, p. 457) observed that the altered dike rock "contained a few hexagonal crystals, which had the form of corundum, but consisted of some decomposition product and showed no trace of the original mineral." These crystals are rare, but they can be found in the fresh dike rock as well as in the weathered material. The crystals are commonly 5 to 15 millimeters in length and the width is about half the length; they have a dull red-brown surface and rough or rounded ends. All are completely altered and consist for the most part of fine-grained, cloudy dolomite and quartz. They are not hexagonal, but probably orthorhombic or monoclinic with pinacoid (010) and prism (110) faces. The angles between the faces, which could be measured only roughly, are about $50^{\circ}$ between prism faces $(110 \wedge 1 \overline{10})$ and $65^{\circ}$ between prism and pinacoid $(110 \wedge 010)$. One of the altered crystals was found surrounded by an aureole of diopside as wide as the crystal; others were observed in direct contact with the surrounding igneous rock. It is difficult to suggest conditions under which crystals, either phenocrysts or inclusions, could be altered completely to quartz and carbonate while enclosed in relatively fresh feldspathoid-bearing igneous rock.

The most common inclusions in the dike are limestone fragments, which occasionally show evidence of reaction in the form of a narrow rim of green diopside, but inclusions of other rocks are not uncommon. Weed $(1899$, p. 9$)$ noted inclusions of quartz, calcite, and pyroxene which "undoubtedly represent altered fragments of the sedimentary rocks carried up in the molten mass at the time the dike was formed." The writer found several small inclusions of a rock that consists of kyanite, quartz, and calcite. Most of the calcite appears to be secondary, like that in the igneous rock. The kyanite is blue, similar in color to some of the pale Yogo sapphires, and it occurs in crystals 2 millimeters or less in length. It is not as abundant as quartz in the granular inclusions. Marginal grains of kyanite have reacted with the lamprophyric magma to produce clots and rims of dark-green 
spinel. The spinel occurs as clusters of extremely small crystals joined together in mosslike, dendritic aggregates, associated with fine-grained, olive-green biotite and an almost opaque brownish-black mineral. Small, colorless needles of an unindentified mineral project into the margins of several of the kyanite grains adjacent to the spinel rim. An irregular border of small feldspar crystals in semiradial groups separates most of the quartz from the enclosing dike rock. The feldspar occurs in small elongate or platy crystals that show indistinct Carlsbad twinning, wavy extinction, and refractive indices lower than that of balsam. A few grains have cores with distinct polysynthetic twinning and higher refractive indices. Most of the feldspar thus appears to be albite or anorthoclase (?) with oligoclase or even andesine in the cores of a few grains. No corundum was observed in the reaction zone.

\section{SAPPHIRES}

\section{DISTRIBUTION}

Sapphires occur throughout the Yogo dike. Gadsden reports that they were found to be almost equally abundant in all parts of the workings, and the writer was able to find small sapphires embedded in the dike rock wherever it was exposed. Sterrett (1908, p. 817) noted that the sapphires occur only in the igneous rock, "none having been observed associated with the limestone inclusions." Kunz (1901, p. 756) reported that the quantity of sapphires in different parts of the dike varied widely. Sterrett (1908, p. 818) observed and explained the variation in sapphire content as follows :

Nearly barren places occur in the dike where the latter seems to be choked with limestone, between the fragments of which there is but little dike material. The barren places commonly occur where the dike pinches down to smaller dimensions, which changes in size were doubtless caused by the jamming of limestone fragments included in the magma in the narrower parts of the fissure at the time of the intrusion.

\section{ABUNDANCE}

Weed (1900, p. 457) wrote that at the time of his visit to the British mine (about 1895), "some 20 loads, each approximately a square [cubic ?] yard of earth, gave between 1,200 and 1,500 carats of cuttable stones." Kunz (1897, p. 420) says that "Several thousand carats were taken out in 1895 , from a preliminary washing of one hundred loads of the 'earth'; of these, two hundred carats were of gem quality and yielded, when cut, sixty carats of fine stones $* * *$ * No accurate record of sapphire recovery in terms of carats per ton of dike rock is available, and it is doubtful that records of this type were kept. The figure given by Weed $(1899$, p. 9$), 60$ to 75 carats per cubic yard (somewhat more than 1 ton of loose material), is probably too high for an average. From incomplete production records the writer esti- 
mates that the average yield was between 20 and 50 carats per ton of dike rock.

\section{SIZE AND COATING}

Most of the sapphires from the Yogo deposit are small; crystals or fragments weighing more than a few carats are extremely rare, and the majority of the cut stones weighed less than one carat. The largest sapphire from the deposit weighed 19 carats, but it was tabular in form and the largest of four signet-ring sets cut from it weighed only $81 / 2$ carats. One of the most valuable sapphires from the deposit was found in 1919, according to Stoddard (1922, p. 170). The stone was cut and sold in Hatton Garden, London, for $£ 400$. It weighed 10 carats in the rough and 5 carats after cutting. The small size of the Yogo gems is commonly said to be a major reason for the closing of the mines in 1929. Not infrequently a whole year passed without the reported discovery of any stone larger than 3 or 4 carats, but Gadsden states that several sapphires of about 12-carat weight were found and that no record was made of many other stones that weighed 5 to 8 carats. He was informed by the London office that in 1921 one 6.25 carat sapphire yielded an excellent 3.40 -carat cut stone which was sold for $£ 40$ a carat.

Although industrial sapphires were only a byproduct of gem mining, they made up a large proportion of the total production. More than 75 percent by weight of the sapphires recovered from the Yogo deposit, chiefly crystals of small size and thin tabular form, were sold as industrial material.

Sapphires in place in the relatively fresh dike rock are invariably coated with a thin layer of hard black material, a fraction of a millimeter in thickness. Under the microscope this film appears to be an extremely fine grained aggregate consisting mainly of dark-green spinel. 'The identiy of the spinel was checked with $\mathrm{X}$-ray powder' photographs. This spinel-rich margin is similar to the reaction border around kyanite inclusions (see p. 17), and in both examples the spinel evidently resulted from reaction of the magma with the aluminous mineral. Further evidence of the reaction between sapphires and magma is found in the etched, pitted, and rounded surfaces of the crystals. The natural etching has destroyed the original crystal faces of most of the sapphires, but it rarely progressed far enough to destroy completely the general form and outline.

\section{CRYSTALLOGRAPHY}

Using a contact goniometer, Pratt (1906, pp. 113-115) identified two crystal forms on Yogo sapphires, the basal pinacoid (0001) and a rhombohedron $(30 \overline{3} 2)$ that intersects the base at an angle of about $67^{\circ}$. A on figure 6 is similar to Pratt's drawing of an idealized crystal 
showing these forms about equally developed. Etch pits on the basal pinacoid were found by Pratt to be bounded by rhombohedral planes parallel to the crystal form $\{10 \overline{1}\}\}$, often in combination with plane surfaces parallel to the basal pinacoid. Several of the types of etch pits shown diagrammatically by Pratt are combined here in $B$ on figure 6 .

The writer was able to identify a number of crystal forms on Yogo sapphires by studying selected small crystals on the reflecting goniometer. Several forms could be identified only tentatively, and it was often difficult or impossible to distinguish between remnants of original faces and plane surfaces developed by the etching process. Reflections were generally poor and confused due to the etch pits and curved surfaces. Most of the smaller crystals are platy, with their least diameter: along the $c$ axis. None exhibited the rhombohedron $\{30 \overline{3} 2\}$ found by Pratt on larger crystals, but several showed a combination of two or three rhombohedrons that intersect the basal pinacoid at lesser angles. The unit rhombohedron, $\{10 \overline{1} 1\}$, as shown in combination with the base in $C$ on figure 6 , is a common form, as is the low-angle rhombohedron, $\{10 \overline{1} 7\}$. The most prominent face on several small crystals is an intermediate rhombohedron, $\{10 \overline{1} 2\}$, usually in combination with the other two, $D$ on figure 6 . All three rhombohedrons appear to be original crystal faces. On the very thin crystal ( $E$ on fig. 6 ) only the rhombohedron $\{10 \overline{1} 7\}$ and the basal pinacoid, $\{0001\}$, were observed. The low-angle rhombohedron could not be identified with absolute certainty due to poor reflections. Measured rho angles generally fell between $10^{\circ}$ and $13^{\circ}$, and the best values were slightly greater than $12^{\circ}$. The calculated rho angle for form $\{10 \overline{1} 7\}$ is $12^{\circ} 41^{\prime}$. As mentioned above, Pratt found etch faces that he assigned to the same crystal form. In all the crystal drawings on figure 6 the crystals have been tilted toward the observer less than the customary amount (about $5^{\circ}$ instead of $9^{\circ}$ ), so that a face of the rhombohedron $\{10 \overline{1} 7\}$ may be seen on the lower side of the crystals on which it occurs.

$F$ on figure 6 is a diagram showing repeated growth of a rhombohedron and basal pinacoid on the base of a crystal.

Pratt noted on one crystal two very small faces which he judged to be faces of a second-order dipyramid. The writer found several second-order dipyramids among the plane surfaces developed by natural etching. They include the following: $\{22 \overline{4} 3\},\{22 \overline{4} 9\},\{44 \overline{8} 9\}$, and possibly $\{11 \overline{2} 6\}$. On a number of small crystals, faces of the form $\{22 \overline{4} 3\}$, which is common on corundum, appear to be remnants of original faces, partly destroyed by etching. On one well-developed crystal the form $\{44 \overline{8} 9\}$ appears to be an original face, also $\{22 \overline{4} 3\}$; and possibly $\{22 \overline{4} 9\}$. Although many of the faces of this crystal are 


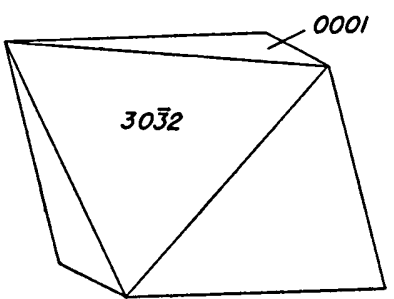

A

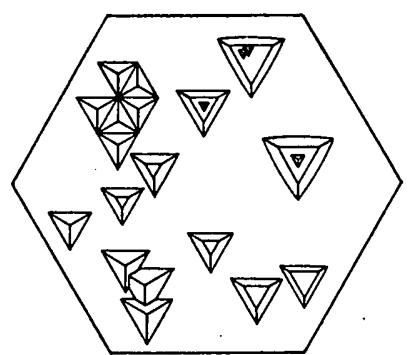

B

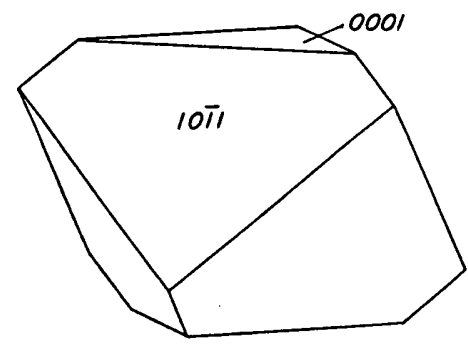

C

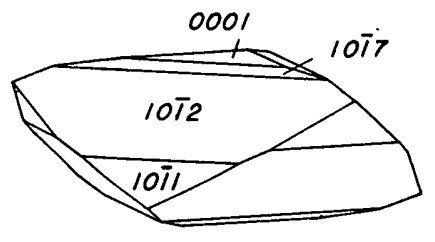

D

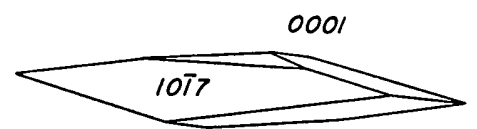

E

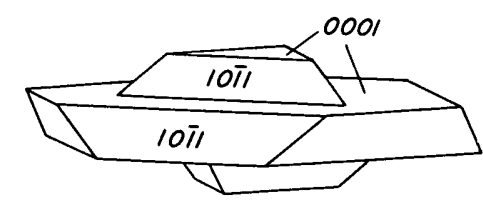

F

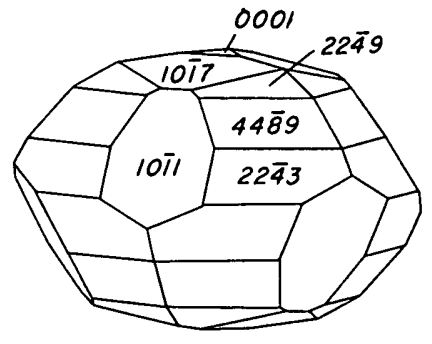

G

Figure 6.-Yogo sapphire crystals. 
small and deeply etched, the observed and calculated rho angles are in good agreement for the three dipyramids. The average rho angle measured from faces of form $\{2243\}$ is $60^{\circ} 50^{\prime}$; the calculated angle is $61^{\circ} 1112^{\prime}$. 'The average measured angle for $\{22 \overline{4} 9\}$ is $31^{\circ} 00^{\prime}$ and the calculated angle is $31^{\circ} 13^{\prime}$; the measured angle for $\{44 \overline{8} 9\}$ is $50^{\circ} 50^{\prime}$, and the calculated value is $50^{\circ} 29^{\prime}$. $G$ on figure 6 is an idealized drawing of a crystal showing the 3 second-order dipyramids in combination with two rhombohedrons and the basal pinacoid. Natural crystals are so rounded and pitted by etching that none of them can be expected to exhibit any marked similarity to this figure. Many natural crystals, however, are recognizably similar to $A, C$, and $F$ on figure 6 .

Crystal planes or faces developed by the natural etching of the sapphires in the magma include all of the rhombohedrons and dipyramids mentioned above, the scalenohedrons $\{32 \overline{5} 4\}, \bullet\{4 \cdot 1 \cdot \overline{5} \cdot 20\}$, and $\{42 \overline{6} 5\}$, and traces of a few other forms which could not be identified with any degree of certainty.

\section{FRACTURE AND SPECIFIC GRAVITY}

Yogo sapphires are entirely free of the parting planes and twinning commonly observed in corundum from many other localities. Crystals from the Yogo dike break with a distinct conchoidal fracture exposing fresh, glassy surfaces. The absence of partings undoubtedly increases the suitability of the stones for cutting into gems.

The specific gravity of a number of small, clear, unfractured crystals of Yogo sapphires was determined by use of a Berman precision balance. Only values that could be checked by repeated measurements were retained. Bright-blue crystals were found to have the highest specific gravity, but the differences between the stones of different colors were small and perhaps not significant. Values obtained using blue crystals ranged from 4.001 to 4.013. Nearly colorless crystals appeared to have slightly lower specific gravity, with an average value near 4.000 . Reddish-purple sapphires gave consistently lower figures that averaged about 3.980, but only a few crystals and fragments of the purple material were available, and the purple sapphires generally possessed a greater abundance of minute fractures and dark-brown inclusions (probably rutile) than the blue and colorless sapphires.

\section{COIOR}

With reference to the Yogo sapphires, Kunz (1897, p. 420) wrote that the colors vary

* * from light blue to quite dark blue, including some of the true "cornflower" tint so much prized in the sapphires of Ceylon. Others incline to amethystine and almost ruby shades. Some of them are "peacock blue" and some 
dichroic, showing a deeper tint in one direction than another, and some of the "cornflower" gems are equal to any of the Ceylonese, which they strongly resemble $* * *$

Unlike the sapphires from other Montana localities almost all the Yogo stones are blue and the color is remarkably uniform through a stone. Zoned or unevenly colored sapphires are almost unknown here, although very common in almost every other sapphire locality in the world. The Yogo stones are not as intense in color as the dark-blue Oriental sapphires, but they are almost as brilliant under artificial light as they are by daylight; whereas the Oriental stones are commonly black and lifeless by artificial light. Lilac- to purple-tinted stones are common at Yogo. Gadsden states that most of these stones were rejected as gems during sorting and sold for industrial use; eventually a few were saved for cutting and some of the dark amethyst-colored cut stones are fully as beautiful as the bright, blue gems. Gadsden also reports that only three or four gem-quality rubies (purplish-red stones) were found during some 30 years of mining.

Most of the Yogo sapphires are mildly dichroic, blue or lilac-blue by light transmitted parallel to the $c$ axis and blue-green by light transmitted normal to the $c$ axis. In order to evaluate the range in color of the Yogo sapphires, the writer divided a 10-gram sample of very small crystals, $1 / 2$ to 2 millimeters in diameter, into four arbitrarily delimited color groups and weighed the fractions, with the following results :

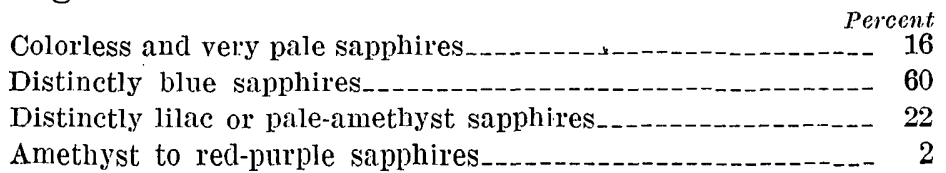

This subdivision can hardly be representative of the larger stones; more than 60 percent of the uncut Yogo sapphires of several carats observed by the writer were blue and only a few were nearly coiorless.

\section{VALUE}

It is difficult to place an exact value on any gem, and it is almost impossible to estimate the values assigned to Yogo sapphires at various times in the past. In general, the price of cut sapphires has shown a marked increase from decade to decade during the last half century or longer, and this increase does not appear to have been affected by the production of excellent and relatively inexpensive synthetic corundum gems. Kunz (1896, p. 909)) reported that 60 carats of fine gems worth $\$ 5$ to $\$ 25$ a carat were cut from 200 carats of selected rough stones in 1895 . Weed $(1902$, p. 282) reported that in 1901 the larger Yogo gems, those weighing several carats when cut, were valued at $\$ 75$ a carat and that the smaller stones retailed at $\$ 30$ to $\$ 40$ a 
carat. According to Stoddard (1922, p. 170), £400 was paid in 1919 for a 10-carat rough stone which weighed 5 carats after cutting.

Industrial sapphires from the Yogo deposit were valued at $\$ 2$ to $\$ 6$ per ounce in 1905 according to Kunz (1906, p. 1338), who states that the Yogo material was in strong demand because the platy form of the crystals required less cutting in the manufacture of watch jewels than was necessary with crystals from other localities. Natural sapphires are no longer in demand for most industrial use, having been displaced during the last few years by synthetic corundum.

\section{ECONOMIC DEVELOPMEN'T}

\section{HISTORY}

The following chronologic record of the development of the Yogo sapphire deposit has been compiled from a large number of sources, many of which duplicate the information contained in others. In order to avoid citation of an excessively large number of references, preliminary acknowledgment of several general sources is given here. 'The volumes of Mineral Resources of the United States published by the United States Geological Survey during the period 1901-24 contain numerous brief acconnts of the Yogo deposit. Somewhat similar: descriptions and summaries may be found in volumes of The Miner:al Industry, now published annually by the McGraw-Hill Book Co., Inc. C. T. Gadsden, manager of the British mine during most of its productive period, supplied much valuable first-hand information during the writer's visits to the deposit. Gadsden also made available a brief history of the New Mine Sapphire Syndicate written in 1925 by Francis H. Wood, president of the syndicate. Specific reference will be made in the text to the more significant published records from which information has been obtained.

About 1878 small deposits of placer gold were found in Yogo Gulch. near the sapphire deposit. Most of the valleys in the region were then prospected for placer gold, and sapphires were first noted in test concentrates from the small valley in which the workings of the British mine are located: J. Hoover, a prospector, was in charge of the work when the discovery was made. The placer claims in the area were held by Hoover and three local ranchers, G. A. Wells, S. S. Hobson, and Matthew Dunn. Soon after the discovery of the placer: sapphires the sapphire-bearing dike was located by another rancher, W. Ettienne (also recorded as James Ettien), who found sapphires in the earth heaped up by gophers along the trace of the dike. Ettienne made no attempt to take up mining claims when he learned that sapphires had never been produced successfully from deposits where they occur embedded in the rock. Hoover, Wells, Hobson, and Dunn eventually traced the dike eastward about a mile and westward about 2 
miles. They located 10 lode claims and decided not to try to extend their holding farther west into the rough country along Yogro Gulch. The western extension of the dike was discovered by two prospectors, Sweeny and Burke, who took up six claims near the junction of Yogo and Kelly Gulches.

Hoover and his three partners met with little success in their placer gold mining, and by 1895 they had turned most of their attention to the mining of sapphires. They organized a company with $\$ 100,000$ capital, and incorporated under the name New Mine Sapphire Syndicate. Wells failed in an attempt to get Tiffany \& Co. to handle the sapphires, but during a visit to his old home in England in the summer of 1898 he succeeded in interesting Johnson, Walker, and Tolhurst, Ltd., who contracted to serve as sole marketing agents for the stones. Soon after Wells returned to Montana, he informed the English company that Hoover had decided to sell his interest in the venture. Brownfield Tolhurst and Edward A. Keller made a trip to America and purchased Hoover's shares in the syndicate. Wells had sold more than half of his shares during his visit to England, and in 1899 Dunn also sold his interest to Johnson, Walker, and Tolhurst and to E. A. Keller. English stockholders thus obtained control of the company, and in 1901 Hobson sold his shares to them. G. A. Wells served as president of the Syndicate until 1910. C. T. Gadsden first came from England to the sapphire deposit in the late spring of 1899 as an employee of the Syndicate; in 1902 he was made superintendent of the mining operations, and he has remained in charge of the property since that time. The British company was highly successful during its early years, and tax-free dividends as high as 30 and 40 percent were paid to stockholders on a few occasions.

Sapphire production from the Yogo deposit was valued at only a few thousand dollars per year during the period prior to 1898 when British capital was invested in the venture and a market for the gems assured. Production then increased steadily and during the period 1902-5 about 1,000,000 carats of gem and industrial sapphires valued at approximately $\$ 40,000$ was produced annually. (See table 1, p. 32.) During the winter of 1902,15 men were employed in underground mining as the new main shaft was sunk. A 9-carat stone was found that year. In 1904 the underground work consisted chiefly of driving levels rather than stoping, and production declined slightly, but improved during the following year.

Producton was curtailed sharply in 1906 by an injunction prohibiting the Syndicate from emptying the tailings from the washing operations into the Judith River where, it was charged, they entered irrigation ditches and damaged the irrigated farmlands below the mine. The Syndicate finally purchased agricultural lands adjacent 
to the mine and thereafter demonstrated that the tailings or "slums" had beneficial rather than harmful effects on vegetation. Sterrett (1908, p. 818) wrote as follows regarding the tailings:

Instead of containing chemicals injurious to vegetation, as claimed by some of the ranchers along the river below the mine, the slums have been shown actually to improve, for raising crops, the lands on which they are turned. Analysis of the slum is also reported to show the presence of nitrates and phosphates, which are helpful to any crop growth. To test this, Mr. C. T. Gadsden, superintendent of the mine, turned the water carrying the slums over portions of the ranch land owned by the company. Oats, alfalfa, and vegetables were successfully grown, both where the slums were turned over crops already planted and where the vegetables were planted directly in thick deposits of slum. In each case vegetation was most luxuriant where the slum was thickest. The coarser sands from the sapphire washings were removed by a sand trap from the sluice ditches, where the grade was low, to keep the latter from clogging up.

A supply larger than ever before of sapphire-bearing rock was mined and treated in 1907, and production reached a new high, but declined sharply during the next three years. In 1910 new washing floors were under construction, and a prolonged drought cut down on water supplies to such an extent that washing operations had to be suspended during part of the summer season. During the year a 19-carat sapphire was found, the largest ever discovered in the Yogo deposit. A 12-carat stone was also reported. In 1911 and 1912 production was about normal for the period-approximately 90,000 carats of gem material and 440,000 carats of industrial sapphires annually. No sapphires of more than 3 or 4 carats were reported.

While the British property was being developed and exploited so successfully, the claims to the west held by American interests were also undergoing extensive development, but without similar financial success. Sweeny and Burke mined the altered dike rock on a very limited scale from small workings just west of the crest of Yogo Hill at the eastern rim of Yogo Gulch. They hauled the rock in wagons to the Judith River for washing. About 1901 the prospectors sold their claims to the American Sapphire Co., incorporated in New York with a share capital of $\$ 500,000$. By 1905 the company had put in more than 2,000 feet of underground workings and was engaged in construction of a mill with a capacity of 100 tons of rock per day. Kunz (1906, p. 1338) recorded a production of 1,564 carats of uncut gem sapphires in 1905; greatly increased production was anticipated after installation of the mill. The mill was reported to be in operation in 1906 , but the company was engaged chiefly in development rather than production. In 1907 the company was still raising funds by selling stock when a general depression struck the country. A few lapidaries were employed at the American mine to cut and polish the 
sapphires, but their work is said to have been decidedly inferior to that done in Europe. About 1909 the American company's capital was exhausted and a new company, the Yogo American Sapphire Co. was organized with a capital of $\$ 100,000$ to purchase the holdings of the bankrupt concern. The new company fared little better than its predecessor, and after five unprofitable years sold its assets to the New Mine Sapphire Syndicate for $\$ 80,000$. The American companies had often been forced to sell their sapphires at prices below those maintained by the more stable British syndicate, which therefore purchased the property chiefly to eliminate unfavorable competition. No further use was made of the underground workings or mill at the American mine, but a large quantity of sapphires was obtained by the British company from reworking the dumps.

In the summer of 1914 only the British company was active, and it ceased operation in August, after the war began in Europe. 'The Syndicate resumed restricted operations in 1915 with the washing of old dumps but undertook no new mining operations. Production was subnormal throughout the war. In 1918 the Syndicate extended its corporation period to 1938. Activities during the following year were handicapped both by a shortage of miners and other laborers and by an inadequate supply of water, which caused washing operations to cease early in August after a period of activity of about 10 weeks. In 1920, production reached a value more than five times that of the previous year. It was the highest value for any year except 1913, in spite of a reported shortage of labor and trouble with the electric separator, which caused the shipment of smaller sized stones in the concentrate for sorting in London. In 1921 production increased in value to almost half a million dollars, more than twice that of any previous year. In February 1922 a larger force of miners was at work underground, and the washing floors were being enlarged. Greatly increased production was anticipated for the summer of the following year. But 1923 brought disaster in the form of a severe cloudburst on July 26, and production for the year declined sharply to a value of only $\$ 40,645$. During the next 4 years production tapered to a value of $\$ 4,860$ in 1927 , and in 1929 the mine was closed completely. Average annual dividends paid by the Syndicate to stockholders in the period 1901-23 was about 15 percent.

The decline in production after 1923 was caused only partly by the damage from the cloudburst. Production costs rose and a labor shortage developed as the country entered a prosperous period. Two other factors contributed largely to the final closing of the mine. One of them was the declining demand for small cut sapphires. The second and more important was increasing double taxation. About 1924 taxes 
on profits were said to be about as follows: English income tax, $22 \frac{1}{2}$ percent; American income tax, $12^{1 / 2}$ percent; Montana State tax, 51/2 percent. In addition, a heavy duty was charged on all gems returned to this country for sale after cutting in Europe.

\section{PRODUCTION METHODS}

Yogo sapphires were first obtained from placer deposits in small valleys that cross the dike. Later they were washed from residual deposits in the soil lying over the dike, and finally from the decomposed dike rock itself. The original discoverers, Wells, Hobson, Dunn, and Hoover, had built a long flume (fig. 2) to bring water from Yogo Creek for washing gold, and this flume supplied water for sapphire mining, first for the prospectors and later for the British company, the New Mine Sapphire Syndicate. The first workings on the dike were open-cuts from which the weathered dike rock was removed by hydraulic mining. The limestone walls were firm and nearly vertical (fig. 3) and the dike thoroughly decomposed to depths of 20 to 50 feet, so that this method was successful where the slope of the hillside was such that water might drain from the lower end of the open-cut. For mining to greater depth in the cuts, or in less weathered dike rock, the sapplire-bearing material was dug out with picks and shovels, or even broken by blasting, screened, and the fine material carted to sluices for washing. Lumps of coarse material disintegrated rather rapidly on exposure to the weather, and eventually the weathered material also could be washed in the sluices. Kunz (1902, pp. 736-737) described the mining operations of 1901 as follows:

The methods employed are a curious combination of those of the California gold workings and the South African diamond mines. As in the latter, the gangue of the gems is an igneous rock, hard below, but decomposed above, in varying diegrees, to a mere earthy mass at the surface. From this last the gems are separated by washing and sluicing, much in the manner of placer gold; though because of the less density of sapphires more care is necessary, and the sluice boxes must be less inclined, to prevent the gems from being carried over the riffles. Most of the New Mine Syndicate's workings are surface openings and cuts, some of the latter very extensive. Water is carried from Yogo Creek, 10 miles distant, by a ditch and flume, with a parallel hydraulic pipe line, and a system of sluices extends all along the company's workings.

Where the rock is much decomposed the hydraulic process is employed largely; as it becomes harder, powder is necessary to break it up. The rock is thrown out in dumps and allowed to disintegrate by exposure to the weather, as with the African "hard blue." This process requires from a month to a year, according to the condition of the material. Sometimes a stream of water is turned on the dumped rock, and the process thus expedited. When sufficiently decomposed, this material is subjected to the same washing process as the material naturally disintegrated.

Some of the open-cuts along the dike are very large. One is $\mathbf{7 0 0}$ feet long and 90 feet deep; another, called the "Blue Diamond cut" is 1,200 feet long and 50

$974878-52-3$ 
feet deep at its greatest depth. The side of this latter cutting gives a very fine section of the dike, showing the entire gradation from the hard rock below to the soft surface condition. The former is bluish or gray, while the latter becomes brown, reddish, and yellowish, from oxidation of the contained iron * * *

In the washing the fine earth is carried away with the water, all hard lumps remaining are again thrown out on a dump to decompose further, and the sapphires, after several screenings, are picked out by hand. All are saved, the larger for gems and the smaller for watch jewels, etc. The minute and imperfect ones are crushed and used for polishing powder, sometimes mixed with diamond dust, in cutting the larger stones.

About 1898 the open-cuts at the surface were nearing exhaustion, and two tunnels were put in-one just west of the present shaft house and another in the hillside east of the valley that crosses the dike 3,000 feet southwest of the shaft house (pl. 1). The main shaft was begun in 1902. A few years later the underground workings were described as follows by Sterrett (1908, p. 818).

At present the sapphire ore is all obtained from underground workings. The latter consist of a shaft $\mathbf{1 0 0}$ feet deep with drifts in each direction from the bottom. The shaft is located in a smaller coulee or valley crossing the dike. The west drift is about 2,000 feet long and nearly 200 feet below the surface of the hill on the west of the coulee, while the level above and one of the stopes reach nearly to the bottom of the 90 -foot open-cut in this hill. The east drift was carried nearly 800 feet, with stopes above at varying intervals. At one place in this drift the dike has been stoped out to the surface.

The shaft was later deepened and new levels were driven several hundred feet in each direction along the dike 250 feet below the surface (fig. 7). Gadsden estimates that approximately 200,000 tons of dike rock was removed from the main workings of the British mine before operations ceased. Most of the mining was done in the winter months when surface operations were impossible because of weather conditions. The limestone walls stand with relatively little need of support, and the dike rock was easily drilled, generally with hand augers, and readily broken with light powder charges. A mule was used to haul the mine cars underground.

The dike rock was dumped on a platform beside the shaft house to weather and disintegrate as much as possible before the summer washing season. The alternate freezing and thawing during the fall and spring accelerated the process. During the summer, streams of water were turned against the dumps and workmen with specially designed pitchforks tossed out the larger fragments of incompletely disintegrated rock. These fragments were allowed to undergo another season or more of weathering on the platform; piles of the more resistant boulders still remain on the old floors. The disintegrated rock and smaller fragments were washed through sluices, which are flat-bottomed wooden troughs with iron-plate floors and removable iron riffles at appropriate intervals. The riffles, which trapped the sapphires and any other heavy materials, were removed at least four times daily for 


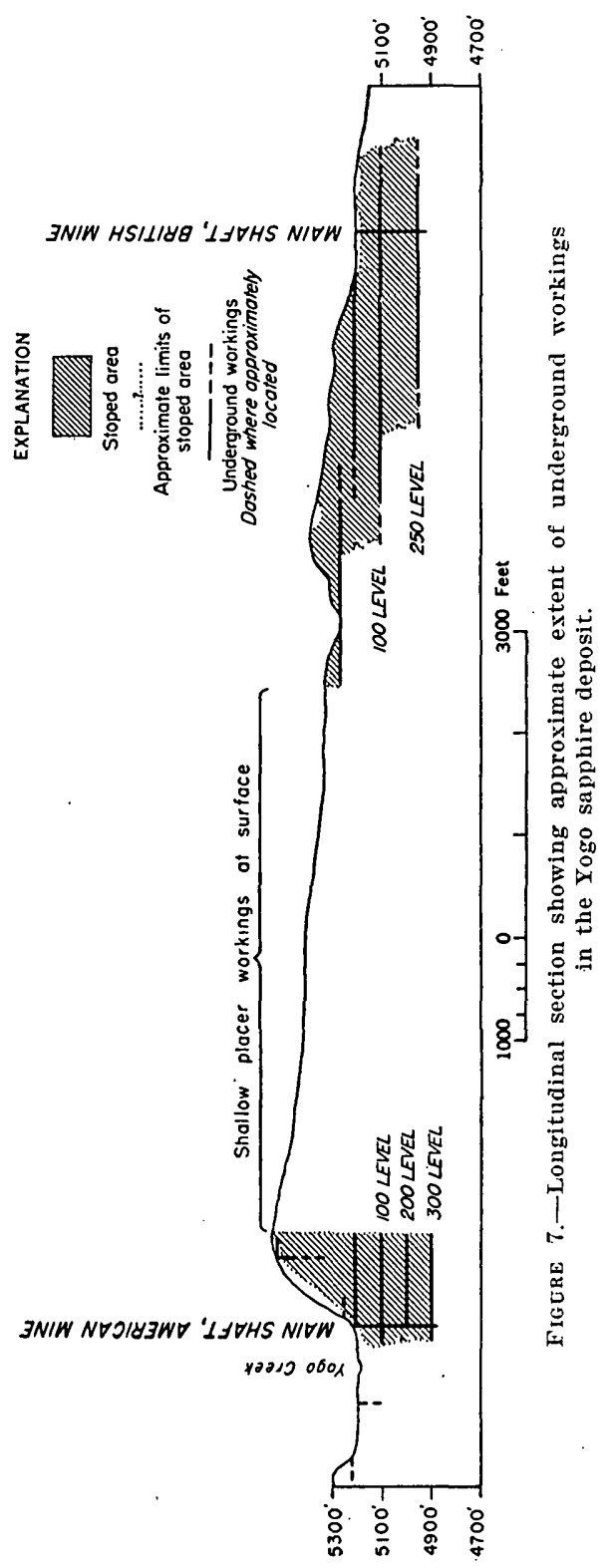


clean-ups. Sterrett $(1908$, p. 819$)$ described the handling of the concentrates in 1907 as follows:

The concentrates are separated in a rocker sieve into three sizes, and each grade is panned down closer over a wooden tank. The oversize left on a screen of $5 / 8$-inch mesh is carefully examined for large sapphires before discarding. The contents of the tank in which the panning is done receive further treatment on screens of two different meshes from those first used. Sapphires are picked up by hand from the coarse sizes of concentrates before shipping.

The material that passed over the riffles included many small fragments of unweathered dike rock, and it was therefore collected in a pond behind a dam a short distance below the weathering floor. After another season of weathering this material also was washed through sluices and over riffles to a second dam, later to a third, and eventually to a fourth. Very little of the dike rock escaped disintegration under this system, and it is probable that few of the sapphires, except the very small platy crystals, were not recovered somewhere along the chain of sluices. The location of the first washing floors and of a later floor at some distance from the shaft, as well as the dams and some of the sluices are shown on the map of the deposit, plate 1 .

Additional refinements in the treatment of concentrates were tried out from time to time. Gadsden designed a small, modified ball mill for gentle abrasion of coarse concentrates that contained coated sapphires which might have been overlooked in hand sorting. A screen with closely spaced rods, rather than woven mesh, was used to screen out platy crystals from the gems. An electrostatic separator was used in cleaning up industrial sapphire concentrates.

At the American mine there was no gradual evolution from simple placer mining to large-scale operation. The company proposed from the first to mine and mill large quantities of dike rock, following the practices of modern metal mining, insofar as possible. Drifts were driven along the dike in the eastern side of Yogo (Gulch) and a shaft was begun at the base of the cliff. Concerning the shaft Sterrett, $(1908$, p. 819$)$ wrote, "It was reported that the depth was about 100 feet early in 1908, and that the shaft was equipped with an electrical hoist capable of sinking to 1,000 feet." The shaft was eventually sunk to a depth of approximately 300 feet below the surface (fig. 7). Flowing water was encountered in a fracture zone cut by one of the lower levels, but the water ran down the drift a short distance and escaped through another set of fractures, so that pumping was never necessary.

Milling operations at the American mine in 1907 were described as follows by Sterrett (1908, pp. 820-821):

It has been found that over 50 percent of the ore removed by blasting is fine enough for milling without disintegration by weathering. The ore direct from 
the mine, after passing through 4-inch grizzlies, is digested with water in heavy revolving screens. The latter discharge three classes of material, the fines or slimes, which are immediately discarded, the oversize or material still in lumps, which is saved for further treatment, and the digested matter ready for sizing and concentration. The lump material is left in stock piles to weather for a period of several months, by which time it is readily digested in the revolving screens and concentrated. After sizing, the digested material is concentrated on Woodbury jigs arranged to treat three sizes, three-fourths and three-eighth inch and 6-mesh. Two jigs are rum in series for safety. These jigs were handling about 75 tons in a day of seven and one-half hours at the time of the visit, though from 200 to 225 tons could be treated in twenty-four hours.

The concentrates from the jigs, in rare cases, run as high as 30 percent sapphire, 5 to 10 percent being more common. The concentrates containing the watch-jewel sizes, or culls, are treated on a Blake-Morscher electrostatic concentrator and their grade brought up to between 50 and 90 percent sapphire. The final cleaning, as with the larger sizes suitable for" cutting, is accomplished by hand picking. In filling hurry orders this cleaner is of value, since it enables a large quantity of sapphire to be selected much more quickly than could be done by hand alone. On the other hand, part of the sapphire goes over with the tailings, which require more labor to pick over than the original concentrates.

The operations of the American Sapphire Company have not yet reached the capacity of the plant, since much time has been consumed in perfecting the method of concentration in use and in exploratory work in the mine. The production of sapphires suitable for cutting amounted to over 100,000 carats between April and December of 1907 . In addition, several thousand ounces of culls for watch jewels, bearings, and instruments of precision, were obtained at the same time.

Freeman (1915, pp. 800-802) described the operations of the two sapphire mines and estimated that only 75 percent of the sapphires were recovered by the sluicing system at the British Mine, but that practically all of the larger stones and 95 percent of smaller stones were recovered in the mill of the American mine. Except for the statements of Freeman, there is no evidence that the milling methods were more efficient in recovering sapphires than the primitive, but highly effective, methods used at the British mine, and the milling procedure was unquestionably more expensive and complex than the sluicing. The American mine was never a financial success, and it threatened the stability of the market in Montana sapphires by forced sales of gems to immediate buyers at lower prices. Freeman reports that in August 1914 the British company purchased the claims and assets of the American concern for $\$ 80,000$. No attempt was made to operate the mine or mill on the American company property following the purchase, but during the summer of 1915 Gadsden supervised the washing of the dumps at the American mine, and in the sluices recovered a quantity of sapphires valued at only slightly less than the purchase price of the whole property.

\section{PRODUCTION AND RESERVES}

Published records of production from the Yogo Sapphire deposit are summarized in table 1, page 32 . From the incomplete data, the 
writer estimates that the total production prior to the closing of the mines amounted to approximately 16 million carats of sapphires valued in the rough at about $\$ 2,500,000$. The American companies probably produced less than 3 million carats; essentially all of the remainder was produced by the New Mine Sapphire Syndicate. About 15 percent by weight of the sapphires was of gem quality, and it represented more than three-fourths of the total value. Production records indicate that the average value assigned to rough Yogo gems was less than $\$ 1.00$ per carat, whereas even the smaller cut stones sold for retail prices of $\$ 30$ to $\$ 40$ a carat as early as 1901. About $21 / 4$ million carats was classed as gem material. It is unlikely that these stones lost more than 70 percent of their weight in cutting. If the finished gems weighed 30 percent of the original total and had an average retail value of $\$ 30$ to $\$ 40$ per carat, some 675,000 carats of cut sapphires worth between 20 and 30 million dollars was obtained from the Yogo deposit.

TABLE 1.-Sapphire production in Montana and in the United States

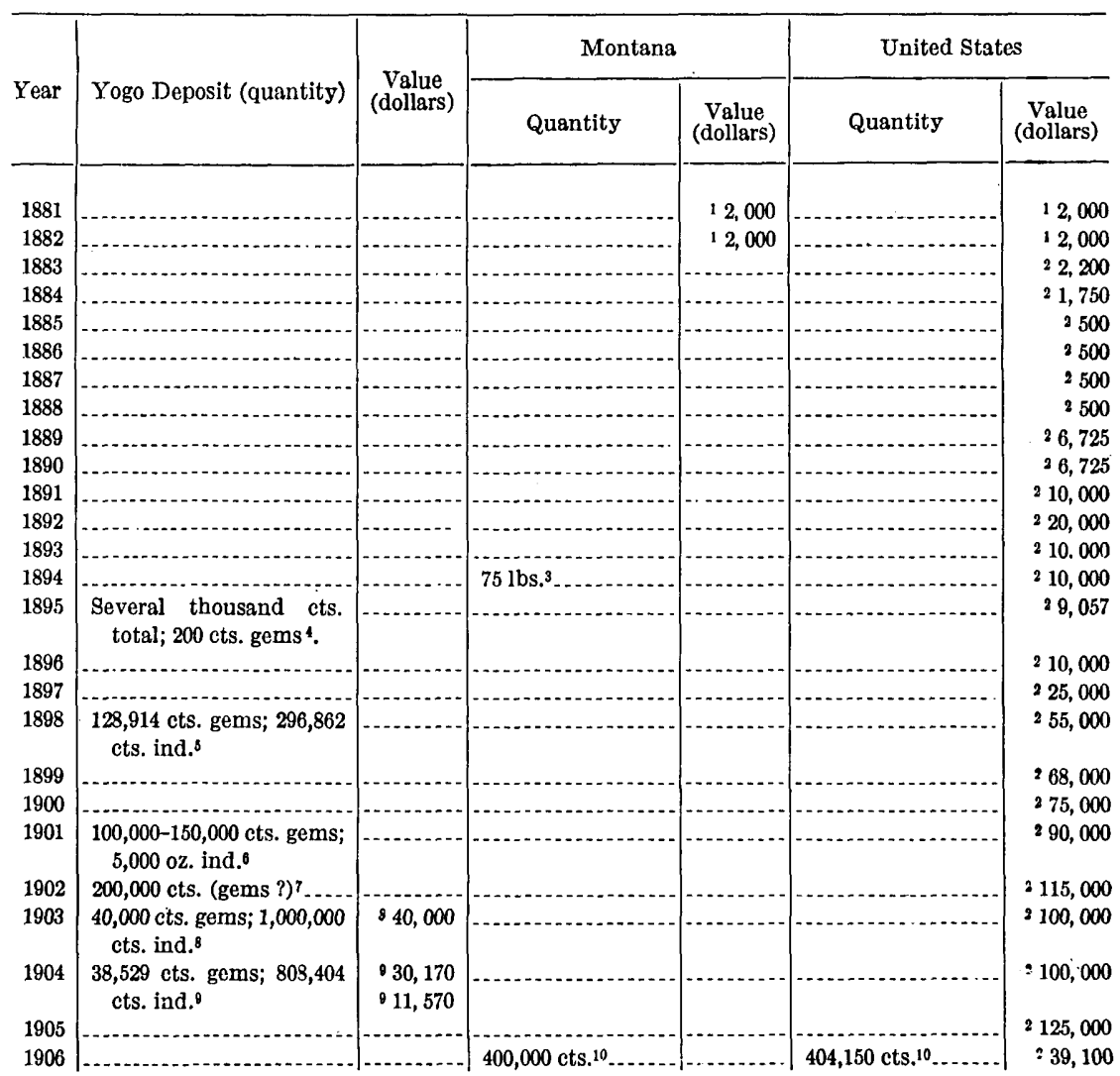

See footnotes at end of table. 
TABLE 1.-Sapphire production in Montana and in the United States-Continued

\begin{tabular}{|c|c|c|c|c|c|c|}
\hline \multirow{2}{*}{ Year } & \multirow{2}{*}{ Yogo Deposit (quantity) } & \multirow{2}{*}{$\begin{array}{l}\text { Value } \\
\text { (dollars) }\end{array}$} & \multicolumn{2}{|l|}{ Montana } & \multicolumn{2}{|c|}{ United Stutes } \\
\hline & & & Quantity & $\begin{array}{l}\text { Value } \\
\text { (dollars) }\end{array}$ & Quantity & $\begin{array}{l}\text { Value } \\
\text { (dollars; }\end{array}$ \\
\hline 1907 & & & $11,000,000$ cts. $^{11} \ldots$ & 11229,800 & $11,000,000$ cts. ${ }^{11}$ & 2229,800 \\
\hline 1908 & & & $1,655,000$ cts. $12 \ldots$ & $\ldots$ & $1,655,402$ cts. $^{12}$. & 258,397 \\
\hline 1909 & 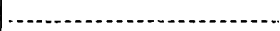 & & 271,185 cts. ${ }^{13}$ & & 271,185 cts.13 $\ldots$ & ${ }^{2} \mathbf{4 4 , 9 9 8}$ \\
\hline 1910 & $\begin{array}{l}70,000 \text { cts. gems; } 2,000 \text { oz. } \\
\text { ind. } 14\end{array}$ & & $1,060,000$ cts. ${ }^{15}$ & $-\cdots$ & $1,062,000$ cts. ${ }^{15}$ & 252,983 \\
\hline 1911 & $\begin{array}{l}90,000 \text { cts. gems; } 410,000 \\
\text { cts. ind. } 16\end{array}$ & - & 88,000 oz. ${ }^{17}$ & 17215,313 & 88,477 oz. ${ }^{17}$ & 2215,313 \\
\hline 1912 & $\begin{array}{l}90,000 \text { cts. gems; } 478,406 \\
\text { cts. ind. } 18\end{array}$ & & & & & 2195,505 \\
\hline 1913 & (n) & & & & & ${ }^{2} 238,635$ \\
\hline 1914 & - n. & & & & & 260,932 \\
\hline 1915 & 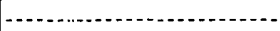 & $-\ldots$ & & & & 1088,214 \\
\hline 1916 & 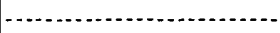 & & $\ldots$ & $\ldots$ & $\ldots$ & 1099,180 \\
\hline 1917 & 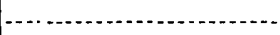 & - & - $\ldots \ldots . . .2$ & $-\ldots$ & $\ldots$ & 1054,204 \\
\hline 1918 & - n. & $\ldots$ & ......... & $\ldots$ & $\ldots$ & 1042,414 \\
\hline 1910 & nan & . n & $\ldots$ & $-\ldots$ & & 1040,304 \\
\hline 1920 & 309,195 cts. ${ }^{20} \ldots \ldots \ldots$ & 20200,325 & $\ldots$ & & & 21 214,705 \\
\hline 1921 & $\ldots$ & $\ldots$ & & & & 21482,745 \\
\hline 1922 & - no.t. & $-\ldots$ & -- & & $\ldots$ & -......... \\
\hline 1923 & $\begin{array}{l}118,800 \text { cts. gems; } 221,746 \\
\text { cts. ind. } 22\end{array}$ & $\begin{array}{r}2336,500 \\
224,145\end{array}$ & & & $\ldots$ & $-\ldots$ \\
\hline 1924 & $\begin{array}{l}46,950 \text { cts. gems; } 278,317 \\
\text { cts. ind. }{ }^{23}\end{array}$ & $\begin{array}{r}2320,263 \\
235,566\end{array}$ & - & & & _ \\
\hline 1925 & $\begin{array}{l}54,495 \text { cts. gems; } 211,873 \\
\text { cts. ind. } 23\end{array}$ & $\begin{array}{r}2329,138 \\
234,237\end{array}$ & - & & & - \\
\hline 1926 & $\begin{array}{l}42,469 \text { cts. gems; } 179,895 \\
\text { cts. ind , } 23\end{array}$ & $\begin{array}{r}2319,000 \\
233,498\end{array}$ & & & & \\
\hline 1927 & $\begin{array}{l}6,451 \text { cts. gems; } 83,235 \text { cts. } \\
\text { ind. }{ }^{23}\end{array}$ & $\begin{array}{r}234,638 \\
23222\end{array}$ & & & & $\ldots$ \\
\hline 1936 & $\ldots$ & $\ldots+\ldots$ & $17,200 \mathrm{oz}^{24}$ & 2625,000 & 17,200 oz. ${ }^{24}$ & 2125,000 \\
\hline 1937 & 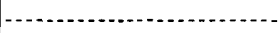 & - n. & 21,469 oz..$^{3 s}$ & 2535,000 & $21,46907.2 s$ & 2s 35,000 \\
\hline 1938 & $\mid$ & $\ldots$ & 9,480 oz. ${ }^{26} \ldots$ & 2611,000 & 9,480 oz. ${ }^{20} \ldots \ldots$ & 2611,000 \\
\hline 1939 & 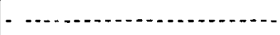 & $\ldots-$ & $1,000 \mathrm{lbs} .{ }^{27} \ldots \ldots$ & 2815,000 & $1,000 \mathrm{lbs} .{ }^{27} \ldots \ldots$ & 2815,000 \\
\hline 1940 & 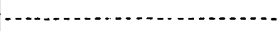 & . & 12,350 troy oz. ${ }^{20} \ldots$ & 2917,000 & 12,350 troy oz. ${ }^{29} \ldots$ & 2017,000 \\
\hline 1941 & $-\cdots$ & - n & 3,720 troy lbs. ${ }^{30} \ldots$ & 3043,000 & 3,720 troy Ibs. ${ }^{30} \ldots$ & 3043,000 \\
\hline 1942 & 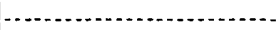 & $\ldots$ & 50,000 oz. ${ }^{31} \ldots$ & 3147,000 & $50,00002.31$ & 3147,000 \\
\hline 1943 & (2) & -- & $20,0000 z .{ }^{32} \ldots$ & 3220,000 & 20,000 0z.32.. & 3220,000 \\
\hline 1944 & - & - nn- & 4,500 oz. ${ }^{33} \ldots \ldots$ & 33300 & $4,50007.33 \ldots$ & 33300 \\
\hline
\end{tabular}

1 Estimate based on statements by

G. F. Kunz (1883, pp. 485-486).

a (Sterrett, 1916, pp. 344-346.)

3 (Kunz, 1895, p. 599.)

- (Kunz, 1896, p. 909.)

s (Kunz, 1899, p. 569.)

B The Mineral Industry, 1901, vol. 10, pp. 279-282, 1902.

7 (Struthers and Fisher, 1903, p. 249.)

- Estimate based on statements by

G. F. Kunz $(1905$, p. 950).

- (Kunz, 1905, p. 950.)

10 (Sterrett, 1907, p. 1243.)

11 (Sterrett, 1908, p. 840.)

12 (Sterrett, 1909, p. 858.)

13 (Sterrett, 1911, p. 808.)

" (Kunz, 1911, p. 582.)

18 (Sterrett, 1911a, p. 899.)
16 (Kunz, 1912, pp. 641-642.)

17 (Sterrett, 1912, p. 1077.)

18 (Kunz, 1913, p. 727.)

10 (Stoddard, 1922, p. 165.)

20 (Kunz, 1921, p. 606.)

21 (Stoddard, 1924, p. 143.)

22 (Kunz, 1924, p. 581.)

23 (Kunz, 1930, p. 550.)

24 (Bail, 1937, p. 1440.)

${ }^{25}$ (Ball, 1938, p. 1292.)

26 (Ball, 1939, p. 1387.)

${ }^{27}$ (Ball, 1940, p. 1455.)

28 Estimated.

${ }^{29}$ (Ball, 1941, p. 1401.)

30 (Ball, 1943, p. 1519.)

31 (Ball, 1943a, p. 1511.)

32 (Ball, 1945, p. 1560.)

23 (Ball, 1946, p. 1517.) 
Mining was carried to a depth of 300 feet below the surface at the American Mine, and dike rock at that depth was found to be altered and subject to rapid disintegration on exposure to the weather. The average width of the dike in all the workings is said to be 8 feet, and the known length is nearly 5 miles. About one-third of the dike rock above a depth of 300 feet has been mined out along the central 2 miles of the dike. A minimum estimate of reserves of altered dike rock is therefore considered to be about twice the amount removed, or approximately one million tons of material containing more than 25 million carats of sapphires, of which some 4 million carats are gem quality. The dike undoubtedly extends downward and to either side several thousand feet beyond the area considered in this estimate, hence a figure several times greater than the estimate given above is not unreasonable.

Small colored gems of all types have been much in demand in recent years in the manufacture of fancy jewelry in the United States, and the value of natural sapphires has continued to rise, in spite of the production of excellent synthetic stones. Therefore it appears reasonable that an American company might acquire and profitably operate the Yogo deposit, producing gems for domestic consumption. Reserves of altered, sapphire-bearing rock are large; relatively cheap methods of extraction have been evolved by the British company, and an American company would not be faced with double taxation, which has prevented reopening of the mines by the present owners. Unfortunately the existing flumes, siphons, sluices, mine workings, platforms, equipment, and many of the buildings have suffered severe deterioration, as must be expected, during two decades of idleness.

\section{MISSOURI RIVER SAPPHIRE DEPOSITS}

\section{LOCATION}

Sapphires were first found in Montana in the gravel deposits along the Missouri River northeast of Helena. 'The deposits in which sapphires occur are chiefly gravel beds lying on benches or terraces that rise to elevations as great as 200 feet above the river level. These gravel deposits are called bars, and most of them have been given names because of their importance as sources of placer gold. Sapphires were said to be most abundant at Eldorado Bar, approximately 12 miles northeast of Helena. 'They were not found farther up the river than Emerald Bar and the lower part of Magpie Gulch near Canyon Ferry, about 15 miles due east of Helena, and they were rarely found below American Bar, approximately 15 miles down the river from Canyon Ferry (fig. 1).

In the region of the sapphire deposits the Missouri River flows northwestward along the foothills of the Little Belt Mountains. At 
Canyon Ferry the river has cut a canyon between the Little Belt Mountains to the northeast and the Spokane Hills to the southwest. The elevation of the river at Canyon Ferry is about 3,600 feet above sea level, and the adjacent hills rise to elevations of 5,000 feet and more. Northwest of the Spokane Hills the river enters the broad Prickley Pear Valley, an arid basin more than 10 miles in width. North of the open valley the river again flows through narrow canyons in the mountains. A scattered stand of pine timber grows in the mountainous areas, but the semiarid lower slopes and terraces adjacent to the river support only sparse vegetation. Dams and hydroelectric plants have been constructed at Canyon Ferry and near the lower end of Prickley Pear Valley.

\section{GEOLOGY}

The geology of the southern part of the region in which the sapphires occur was mapped by J. 'T. Pardee and Russell Gibson (Pardee and Schrader, 1933, p. 15). The rocks in the area of the sapphire deposits are varied; they include argillites of the pre-Cambrian Belt. series, Paleozoic sedimentary rocks, Tertiary "lake beds" and volcanic material, and igneous intrusives of Cretaceous or Tertiary age.

During the summer of 1945 the Canyon Ferry region was remapped in greater detail by a group of geologists of the Geological Survey under the direction of $\mathrm{J} . \mathrm{B}$. Mertie, $\mathrm{Jr}$. The writer is indebted to the members of this party, particularly to S. W. Hobbs and R. P. Fischer, for their assistance during his brief examination of the region.

At most of the bars the gravels rest on argillaceous rocks of the Belt series. The gravels commonly include particles of varied size, ranging from sand to boulders several feet in length. In some places the gravels attain a thickness of more than 40 feet, and locally they have been mined to depths as great as 30 feet. Sterrett (1911a, p. 879) states that the bars that have been most worked for gold and sapphires are more than 100 feet above the river. Eldorado, Gruell, French, and Spokane Bars are described by Sterrett (1911a, pp. 879-880), and several of the major placer gold deposits that supplied sapphires are described also by Pardee and Schrader (1933, pp. 180-182).

Late in $1889 \mathrm{Kunz}$ (1890, p. 49) was shown specimens of "a trachyte rock" containing sapphires similar to those found on Eldorado Bar. He reports that the rock came from a dike on the river: near and above Eldorado Bar, and he concluded that the sapphires of Eldorado Bar were derived from this rock by weathering and river transportation. Later Kunz reported the discovery of a mastodon tusk in the gravels of Ruby Bar, which convinced him that the gravels were of glacial origin. He described as follows the occurrence of a 
sapphire-bearing dike at Ruby Bar (Kunz, 1893, pp. 543-544; 1893a, p. 400) :

In regard to the original source of the sapphires itself it is worthy of note that during the winter of 1889 and 1890 an eruptive dike was found cutting the slaty rock at Ruby Bar, on which rests the glacial gold gravel. In this eruptive rock were found crystals of sapphire, pyrope, garnet, and sanidine feldspar. There seems little doubt that all the sapphire along the bars of the Missouri River has come from the breaking down of a rock similar to this. It is evident that some outcroppings have been eroded by glacial action north of all the bars, but from what precise locality is not yet known. It cannot have come from the dike at Ruby Bar, as this locality is 6 miles south of Eldorado Bar, where a quantity of sapphires were found, but rather from some others now worn away or covered over farther to the north. Mining in this district will probably bring to light other dikes, as did the drifting of a level at Ruby Bar some hundreds of feet from the outcrop of the original 4-foot dike. The rock is shown by Mr. H. Miers to be a vesicular mica-augite-andesite, containing an abundance of brown mica and porphyritic crystals of augite. The groundmass consists chiefly of feldspar microlites with a considerable amount of glassy interstitial matter and much magnetite. Many of the cavities are occupied by a brown glass which appears yellow in thin sections and displays a spherulitic structure originating in the sides of the cavities.

The argument presented by Kunz for origin of the sapphires in dikes north of the region in which they occur is based apparently on the assumption that the gravels are of purely glacial origin and that glacial ice moved southward, hindered not at all by local mountain configurations. Actually the gravels are river gravels that were stranded on benches above the level of the stream as it eroded its channel more deeply through a region of moderately rough topography during and since the Pleistocene. The river flows northwest, hence some of the sapphires found at Eldorado Bar undoubtedly were derived from the dike 6 miles south (upstream) at Ruby Bar.

None of the bars is called Ruby Bar at present, and apparently none was known by that name in 1906, for Pratt $(1906$, pl. VI) does not show a Ruby Bar on his index map. Pratt (1906, p. 107) did, however, report the occurence of a sapphire-bearing dike:

At French Bar, about 3 miles below Canyon Ferry, a narrow dike, 3 to 6 feet in width, that had greenish sapphires scattered sparingly through it was found in 1900. This dike was encountered about 50 feet above the river and its strike as it cuts through the slate is N. $10^{\circ}$ E., the dip being about $45^{\circ} \mathrm{W}$. This rock is undoubtedly of the same character as that described by Kunz as occurring at Ruby Bar.

The dike at French Bar is probably the same feature as that described by Kunz, rather than a second locality as Pratt assumed. The dike is exposed both at the surface and in an old drift, as Kunz mentioned, and French Bar is only a little more than 6 miles southeast of Eldorado Bar, the location indicated by Kunz for Ruby Bar.

The dike was originally exposed in a small dry gulch or draw at the east end of French Bar, within a few hundred feet of the river 
bank and about 50 feet above the river level. Only a caved pit and a pile of fragments of the rock mark the locality at the present time, but in a short adit about 150 to 175 feet northeast of the pit, the dike, or a similar one, is exposed in place in a fractured zone in the argillite. It is approximately 2 to $21 / 2$ feet/wide, and the strike is N. $10^{\circ} \mathrm{E}$., the dip about $50^{\circ} \mathrm{NW}$.

Fragments of the dike rock are light brown to gray in color. Vesicles are generally abundant, some are several millimeters in length, and many are filled with chalcedony or with calcite. The "brown glass" with spherulitic structure which. Miers noted in cavities was probably amygdules of chalcedony. Biotite is the most conspicuous mineral in the rock. It occurs in phenocrysts which range in length from less than 1 millimeter to more than 1 centimeter. It is strongly pleochroic from brown to nearly colorless. The flakes are uniform in color, and very little alteration of biotite to chlorite was observed. The augite phenocrysts are extensively altered to olive-brown serpentine and calcite. They are commonly a few millimeters or less in diameter and show euhedral outlines. Remnants of fresh augite in the serpentine are colorless, optically positive, and have an optic angle of about $60^{\circ}$. Small patches of secondary calcite and serpentine (?) are abundant throughout the rock. The groundmass appears to be dominantly glassy; it contains innumerable minute magnetite crystals, rarely as much as 0.1 millimeter in diameter, and an abundance of feldspar microlites. The feldspar microlites are generally less than 0.5 millimeter in length, a few exhibit distinct albite twinning, and most of them show simple Carlsbad twinning. The extinction angle $(X \wedge c)$ of $40^{\circ}$ to $45^{\circ}$ indicates that the feldspar is calcic labradorite. Garnet crystals and pale greenish or colorless sapphires occur very sparingly in the rock. Several euhedral garnet crystals $1 / 2$ to 1 millimeter in diameter were observed as inclusions in one pale blue-green sapphire in the dike. No garnet inclusions were found in the placer sapphires. A few glassy crystals of quartz were found in the rock; all of them appear rounded as if partly resorbed by the magma, and each is surrounded by a border of soft altered claylike material. The quart\% grains may be included fragments of foreign material rather than phenocrysts.

The rock is so fine-grained and altered that its mineralogical composition could be determined only approximately. It is estimated to be about as follows:

\begin{tabular}{|c|c|}
\hline $\begin{array}{r}\text { Percent } \\
\text { by volume }\end{array}$ & $\begin{array}{l}\text { Percent } \\
\text { by volume }\end{array}$ \\
\hline ylass & Biotite \\
\hline abradorite _..._- $40-50$ & Magnetite and others_-_-_- \\
\hline
\end{tabular}


The name used by Kunz and Miers, vesicular mica-augite andesite, is adequate, but it cannot be applied with certainty until a chemical analysis is made to determine the nature of the glassy groundmass.

The presence of a monzonite stock and numerous associated dikes and sills at the upper limit of sapphire distribution along the Missouri River suggests that these igneous rocks may be the source of some of the sapphires. With this possibility in mind, the writer examined a number of exposures of the monzonite and related intrustives in the field and collected material for microscopic study. No rocks similar to the sapphire-bearing dikes were found, and no sapphires were observed. At Emerald Bar, on a high terrace 130 feet above the river, the gold-bearing gravels rest on monzonite bedrock and include many large boulders of the monzonite. Sapphires are said to have been found here, but they were evidently not abundant, and the concentrates from a number of pans of gravel from the old drifts contained gold but no grains of sapphires. Samples of the heavy sands concentrated by wave action along the shore of Lake Sewell near the southern end of the stock were also panned and subjected to heavy liquid separations and microscopic study, but no sapphire fragments were detected.

It is surprising that only one occurrence-or two, if Ruby and French Bars are not the same-of sapphire-bearing rock has been found. The nature of the rock lias been known since 1889, and the region has been prospected with unusual thoroughness for gold and sapphires. Bedrock is well exposed in canyons, on rough slopes near the river, and where the gravels have been washed from acres of bench land, but other dikes have not been reported. Thus dikes of the rock appear to be rare, but if they are the source of the sapphires found in some abundance along 15 miles of the river gravels, they must occur somewhere in the region in considerable number. Pratt (1906, p. 107) comments that "As the sapphires are scattered so sparingly through these dikes, the amount of decomposition and erosion that was required to liberate those that are now found in the gravels must have been enormous." The dike at French Bar is highly vesicular, indicating that it crystallized under low pressure, possibly at shallow depth. This dike, or related dikes may have reached the surface and formed local lava flows or pyroclastic deposits, from which the sapphires in the river gravels were later derived. The suggestion that sapphire-bearing lava or pyroclastic material may have been present is pure speculation. No volcanic material of such nature has been found in the region, but the similar sapphires of Rock Creek, in Granite County, are closely associated with tuffs and may have been derived from the pyroclastic rocks.

Kunz (1897, pp. 417-418) found the following minerals associated with the sapphires in the placer gravels: garnet, gold, topaz, 
kyanite, stream tin, chalcedony, and limonite pseudomorphs after pyrite. The garnet was incorrectly identified as spinel by Smith $(1873$, p. 185) in the first published description of the sapphires. Garnet associated with the sapphires is chiefly bright red to pale orange-red, or reddish pink. Gems of bright color and remarkable brilliance have been cut from the larger fragments found in the sapphire and gold concentrates. As noted above, the garnet occurs in the sapphire-bearing dike rock. The refractive index of the garnet is 1.770; the specific gravity, 3.87 ; and the length of the unit cell as determined from $\mathrm{X}$-ray powder photographs, 11.54-11.55 angstroms. These properties indicate a composition intermediate between pyrope and almandite.

\section{SAPPHIRES}

Kunz (1890, p. 49) described the sapphires from the Missouri River gravels as follows:

The Montana specimens rarely exceed $1 / 4$ inch to $1 / 2$ inch in length. They are brilliant but usually of pale tints. * * The gems are usually of a lightgreen, greenish-blue, light-blue, bluish-red, light-red, and the intermediate shades. They are usually dichroitic, and often blue in one direction and red in another, or when viewed through the length of the crystal, and frequently all of the color's mentioned will assume a red or reddish tinge by artificial light. A fine piece of 9 carats was found of a rich steel blue. A very beautiful piece of jewelly, in the form of a crescent, was made of these stones by Tiffany and Co., in 1883; at one end the stones were red, shaded to bluish-red in the center, and blue at the other end; by artificial light the color of all turned red. Perfect gems of from 4 to 6 carats each are frequently met with. Occasionally crystals are found which would afford ruby and sapphire asterias of a poor quality.

The pale tint of most of the sapphires of gem quality has prevented their popular acceptance as valuable gems and contributed to the failure of more than one company organized to mine them. Many of the sapphires are almost colorless. Pale blue-green, light blue, and light green are the commonest colors; pale purplish-blue sapphires are not uncommon; and very attractive oriental amethyst and oriental emeralds have been cut from some of the darker purple and darker green stones. Darker blue, pink, reddish-purple, and yellow gems are rare. Pink and reddish-purple sapphires show the most pleasing color in light transmitted parallel to the hexagonal axis, and may appear greenish brown when viewed transverse to the principal axis. One dark blue-green stone was observed to have the color change of an alexandrite, being distinctly reddish purple by artificial light.

The sapphire crystals commonly exhibit a faint zonal distribution of color with the zone of lightest color in the center elongated parallel to the hexagonal axis. A few have more brightly colored central spots and others show distinct bands of color. Many of the crystals exhibit a silky sheen or chatoyancy, commonly called "silk." This 
usually takes the form of a hexagonal web that reflects light most brightly through the basal pinacoid. It is due to clusters of minute negative crystals or cavities in zonally distributed linear swarms parallel to the adjacent prism faces. The larger negative crystals are about 0.005 millimeter in diameter; they have hexagonal or triangular outlines, and appear platy. Very few of the cavities are elongate and therefore they do not reflect oriented bands of light as do the inclusions in star sapphires.

Most of the sapphires are slightly rounded and worn, and a few are well rounded, but crystal faces can generally be recognized. Even the least-worn crystals have rough, pitted, and striated faces. Using the contact goniometer Pratt (1906, p. 109) determined that the unit prism $\{11 \overline{2} 0\}$ is always present, usually combined with the basal pinacoid $\{0001\}$ and unit rhombohedron $\{10 \overline{1} 1\}$. On some crystals he also found a pyramid of the second order $\{22 \overline{4} 3\}$. Drawings of typical crystals are given in figure $8 . A, B$, and $C$, on figure 8 , are taken from Pratt's diagrams of idealized crystals; $D$ and $E$ are drawn from numerous examples of natural, distorted crystals from Missouri River deposits; and $F$ and $G$ are similar crystals from the Rock Creek sapphire deposit.

\section{HISTORY AND PRODUCTION}

According to Kunz (1894, pp. 692-693) the earliest recorded date of discovery of sapphires in Montana was

* * May 5, 1865, when they were found by Mr. Ed. R. Collins, an earnest and reliable prospector, on claim No. 4, before the discovery of Eldorado Bar. A stone was cut by Messrs. Tiffany \& Co., and another by Messrs. M. Fox \& Co., New York City. Mr. Collins also sent stones to an Amsterdam diamond cutter and other parties abroad, endeavoring to find a market for them.

Although the location of "claim No. 4" is not clear, it was undoubtedly in the region of the Missouri River sapphire-bearing placers, and other occurrences were recognized soon thereafter. A few years later J. Lawrence Smith (1873, pp. 185-186) published the following description of the Missouri River sapphires:

About a year ago a quantity of rolled pebbles were sent to me from the territory of Montana, which upon examination I found to consist principally of: corundum; they were like the rolled pebbles from the ruby localities in the East Indies, each one being a little crystal in itself, more or less abraded on the angles, and being of a compact uniform structure. They were either colorless or green, varying in shade from a light to a dark green; some were bluish green, but none red; there were some red pebbles, but on examination they proved to be spinel.

These pebbles are found on the Missouri River near its source, about one hundred and sixty miles above Benton; they are obtained from bars on the river, of which there are some four or five within a few miles of each other. In the mining region of this territory on these bars considerable gold is found, it having 

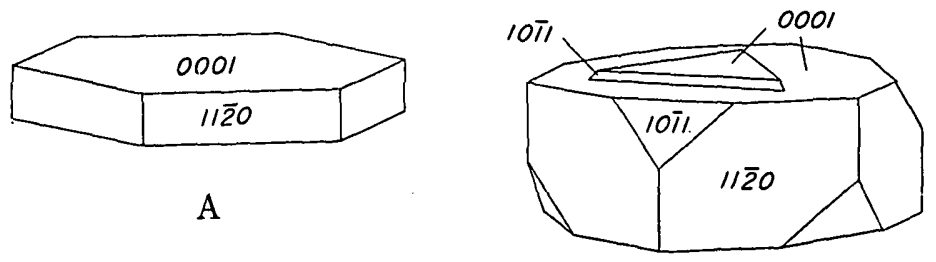

B
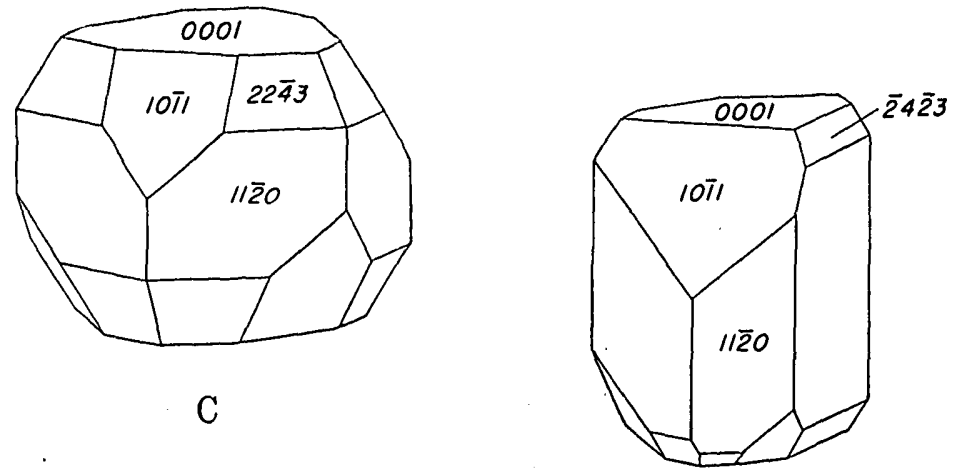

D

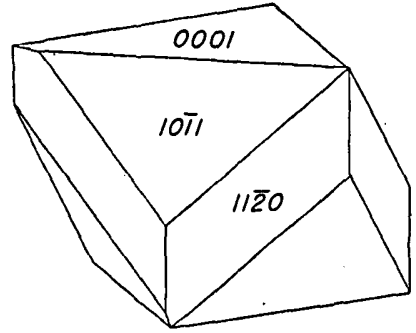

E

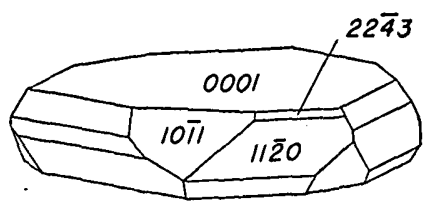

F

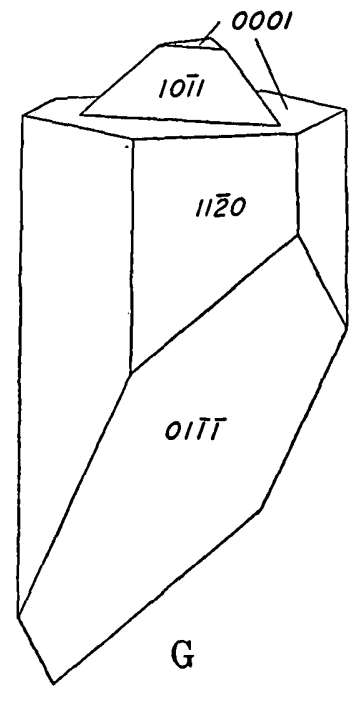

Figure 8.- Sapphire crystals from the Missouri River and Rock Creek sapphire deposits. 
been brought down the river and lodged there, and the bars are now being worked for the gold. The corundum is found scattered through the gravel (which is about five feet deep), and upon bedrock. Occasionally they are found in the gravel and upon the bedrock in the gulches from forty to sixty feet below the surface, but it is very rare in such localities. It is most abundant upon the Eldorado bar situated on the Missouri River about sixteen miles from Helena; one man could collect on this bar from one to two pounds per day.

I have had some of the stones cut, and among them one very perfect stone of three and a half carats, and of good green color, almost equal to the best oriental emerald.

My opinion is that this locality is a far more reliable source for the gem variety of corundum than any other in the United States I have yet examined.

During the summer of 1899 the gravels of Metropolitan Bar were worked on a small scale for gold and sapphires (Pratt, 1906, p. 108). Washing was done in hand rockers on a number of individual claims. Among the claim owners were Robbin Bird, Charles Johnson, and John Durrant, of Helena, Mont. Prior to 1891, gems valued from a few hundred to two thousand dollars were produced annually, but there was no systematic sapphire mining; most of the sapphire production was a byproduct of placer gold mining.

The Montana Sapphire and Ruby Co., Ltd., was incorporated in London with a reported capital of $£ 450,000$, with which to undertake extensive production of sapphires. The company purchased or obtained an option upon an area of about 4,000 acres on Eldorado Bar and adjacent bars in 1889 (Kunz, 1893, p. 543). Mining engineers who examined the property for the company estimated that Eldorado Bar would yield about 2,000 ounces of sapphire per acre. During 1892 the Montana Sapphire and Ruby Co. (also called the Ruby and Sapphire Mining Co.) actively worked its properties "under the superintendence of the well-known mining engineer, Mr. E. G. Wood, who, it is said, lays considerable stress on the placer gold that he hoped to find in connection with the sapphires." (Kunz, 1893, p. 762.) The sapphires were shipped to London where some of the cut stones were exhibited to the public. Kunz questioned whether the world gem market would accept the pale colors of the fancy sapphires. In 1893 the company offered Montana sapphires for sale on the London market, and a lapidary cut and sold Montana sapphires in one of the main aisles of the Mining Building at the World's Fair in Chicago. The stones apparently did not meet with ready sale in London, and the poor financial shape of the company described as follows by Kunz $(1894$, p. 692$)$ :

At a meeting of the Montana Sapphire and Ruby Company, held in London, December 18,1893 , a deficit of $£ 6,000$ was shown, $£ 158$ only having been realized from the sale of gems during the past year. It was also shown that in this company, which was supposed to have been incorporated with a capital of $£ 450,000$, apparently not more than one-tenth of that amount had been subscribed; as the 
underwriters, among whom were the Marquis of Lorne, Duke of Portland, and the Duke of Leinster, representing $£ 370,000$, had withdrawn, so that in reality only $£ 45,000$ had been actually paid in.

The company was reorganized in 1897 as an American company, the Eldorado Gold and Gem Co., with A. N. Spratt of Oakland, Calif., president, and Frank Spratt of Helena, Mont., manager, but no active work was undertaken by the new company (Pratt, 1906, pp. 107-108).

About 1890 several smaller companies also were organized to mine sapphires along the Missouri River. Among them was the Spokane Sapphire Co. which planned to mine from Spokane Bar. The Montana Gold and Gem Mining Co. was incorporated by a group of Helena businessmen in October 1892. The company acquired about 2,000 acres of placer ground on Emerald Bar and at the mouth of Prickley Pear Creek and undertook the mining of both gold and sapphires (Kunz, p. 762). None of the companies continued in operation very long. Weed (1902, p. 281) summarized the economic history of the gem deposits as follows:

As investments these bar deposits have not been remunerative because the stones are chiefly of a pale greenish yellow color, and though very brilliant, are not highly esteemed by the public. Blue and red stones of fine color are extremely rare, and the pink and yellow ones not common enough to be counted upon in washing the gravel. The Missouri River bars are therefore not now worked, and the heavily capitalized corporations formed to mine the gems are financial failures.

When Sterrett visited the Missouri River localities in 1910 he found that "with the exception of a small amount of placer mining at intervals by individuals, no mining has been carried on for several years" (Sterrett, 1911a, p. 877). He wrote (p. 878) that "There has been litigation over the properties and valuable flumes and siphons have been allowed to fall to pieces. Much of the property is now owned by A. N. Spratt of Helena."

Many of the placer deposits have been partly or completely submerged in lakes formed by the installation of dams on the Missouri River near Helena. This condition has made the recovery of gold and sapphires by large-scale dredging economically feasible at some localities. During the period 1940-44 the Perry-Schroeder Mining Co. of Helena operated its gold dredge at Eldorado Bar and recovered about 50,000 ounces of sapphires, almost all of which was sold for industrial use. After the orders closing gold mines were issued in 1942 the company was permitted to continue operation because of its sapphire byproduct (Ball, 1943a, p. 1511). H. L. James and W. R. Jones of the Geological Survey visited Eldorado Bar to observe the operation of the dredge in January 1943. James reported that the 6-foot bucket dredge handled about 5,000 cubic yards per month. The sap- 
phires collected in the jigs used for concentrating gold, and periodically were removed. The sapphire concentrate was given a rough sorting in the office of Eldorado Bar and cleaned in a tumbling barrel with dilute hydrochloric acid. The final sorting, sizing, and grading was done in Helena. In his unpublished report James describes the sorting as follows:

In the Helena office, the gems are sized first on a regular screen, then on an ingenious "third dimension" sizer, which consists simply of two parallel, inclined rolls, one on an eccentric cam, which rotate upward. The gems roll down over this sizer and the thin plates (which will not pass through a screen sizer) drop through between the rolls.

The grading, based on clearness and absence of flaws, is done over a glasstopped table with fluorescent lighting from below.

Owen Perry, of the Perry-Schroeder Mining Co., stated that the sapphire content of the gravel was small, only about 1 troy ounce per 100 cubic yards. The amount of sapphire obtained during part of the operation was even less-about 0.4 ounce per 100 cubic yards. This was hardly more than the gold content. The larger sapphires with attractive coloring, chiefly pale greenish-blue crystals weighing from 4 to 7 carats, were saved for sale as gems. Some of them are sold locally to tourists and collectors at 25 cents per carat. The average price obtained for better grades of industrial sapphire was between one and two dollars per ounce, but the price declined sharply late in 1943 when synthetic corundum became more generally available for watch jewels and instrument bearings. About a ton of culls was sold to American Abrasives Co. for use in special types of small grinding wheels.

It is impossible to determine the total quantity of sapphires produced from the Missouri River placers because the records that have been preserved are highly incomplete. Eldorado Bar has probably yielded considerably more than 50,000 ounces, and several other bars were worked extensively for sapphires and gold. Therefore the total for the region is surely greater than 100,000 ounces, possibly as much as one-half million ounces, a small fraction of which was gem quality.

Many sapphires remain in the river gravels of the region, but it is doubtful that more than a few will be recovered in the future as a byproduct of gold mining. Most of the gold deposits have been mined out, and synthetic corundum has nearly destroyed the demand for industrial sapphires. The Perry-Schroeder Mining Co. sampled placer ground along the main channel of the Missouri River and the the east shore opposite French Bar in the summer of 1945 in preparation for further gold dredging. At that time Perry planned to continue the recovery of sapphires. 


\section{ROCK CREEK SAPPHIRE DEPOSIT}

\section{LOCATION}

Sapphire mining in the Rock Creek deposit has centered chiefly in and adjacent to two tributary gulches on the north side of West Fork: of Rock Creek, about 16 miles southwest of Philipsburg in Granite County, Mont. (See fig. 1.) The west gulch is known as Anaconda Gulch; the other, about a mile and a half to the east, is now called Sapphire Gulch, although in earlier reports it was generally called Meyer Gulch. Anaconda Gulch flows southeast, and in its upper reaches it receives several small tributaries, one of the largest of which is Cold Creek. Sapphire Gulch drains southward from a divide about 6,450 feet in elevation. North of the divide a few sapphires have been found in small gulches that drain northeastward to Rock Creek. Placer deposits extend through an area of several square miles, as indicated on the accompanying map, figure 9, by the extent of the holdings of the American Gem Mining Syndicate.

\section{GEOLOGY}

The bedrock in the lower part of Sapphire Gulch is chiefly gray to purple argillite of the Belt series. It is overlain by igneous rocks of Tertiary (?) age, most of which are volcanic material although some intrusive bodies are probably present. Associated with the igneous rocks are tuffs, conglomerates, and gravels. The geology of the area has never received thorough study, and the details are not readily apparent, for most of the hillsides are wooded and soil-covered. The brief description of the area by Sterrett (1908, pp. 822-823) is perhaps the most helpful that has appeared. He found outcrops of tuff or conglomerate at several places on the small stretch of flat country through which Anaconda Gulch cuts a rather steep valley. Adjacent to one of these outcrops sapphires had been washed from the surface debris. Fragments of porphyry, tuff, and conglomerate are spread widely over the area. The conglomerate consists of pebbles of quartz, sandstone, quartzite, chert, and a serpentinelike material. Larger blocks of similar serpentinelike rock were found on the flats near the gulches. Sterrett described the gravel deposits in the two gulches as follows:

The gravels in Anaconda Gulch vary from 30 to 100 feet in width and from a few inches to 8 or 10 feet in thickness. At the bends and in some of the hollows along the gulch gravel bars extend up the hillsides short distances. On portions of the flats along the gulch gravel beds occur, and good deposits of sapphire are reported to exist in channels leading to the gulch. At one place on the flats the gravels, and probably also the decayed tuff or conglomerate, have been washed for sapphires over an area of a number of feet square. The gravels in Mejer 


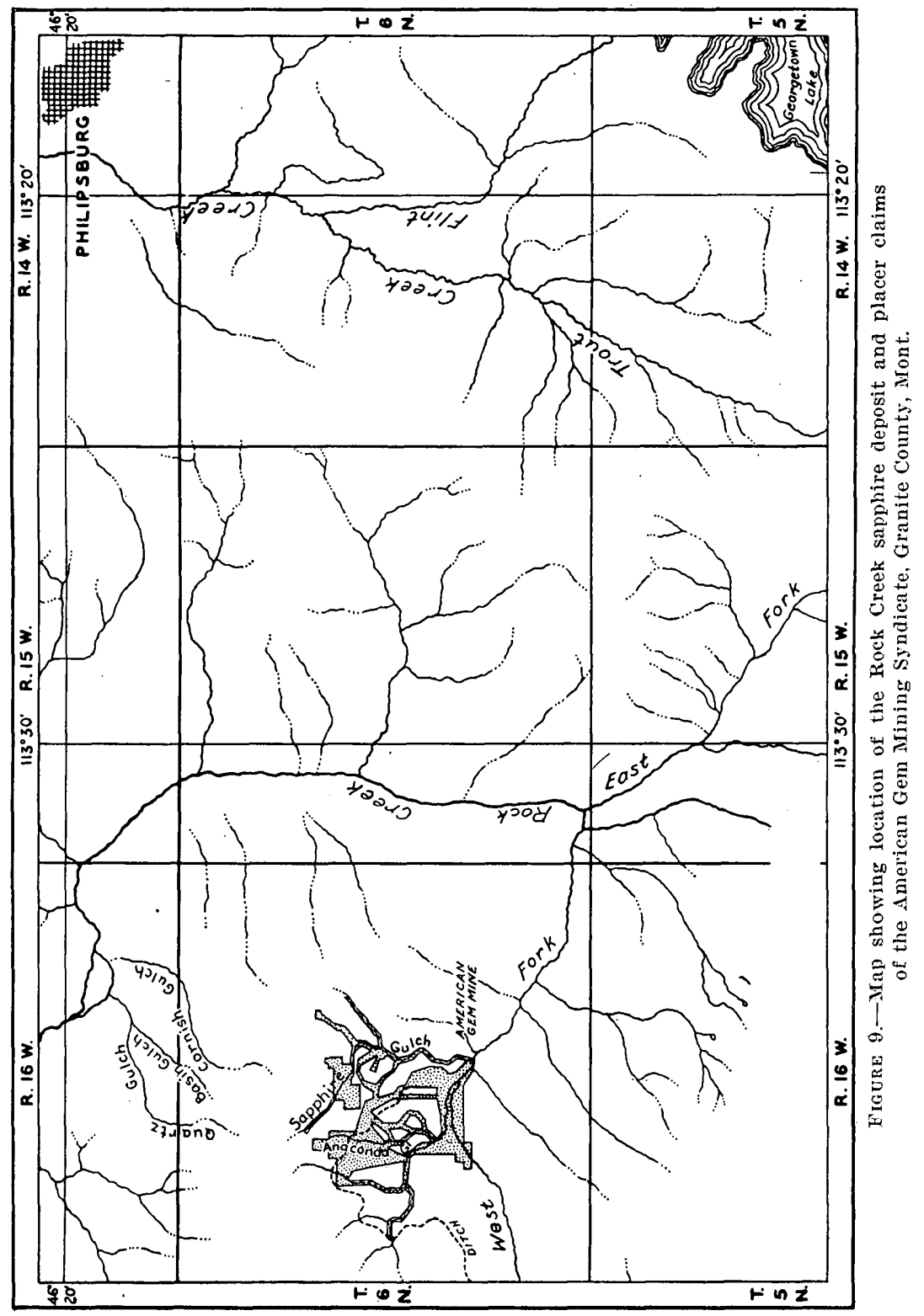


Gulch are from 30 to 40 feet wide in the lower part and from 100 to 200 feet wide farther up the gulch. In thickness they vary from a foot or two up to 8 or 10 feet, and are probably as much as 5 feet thick over a large portion of the area.

The writer collected specimens of common types of rock from the gravels of Sapphire Gulch. Most of these specimens proved to be quartz-rich porphyritic igneous rocks and pyroclastic rocks of lightgray or brown color. A few boulders of dark porphyry and of the dark serpentinelike rock were noted. Some specimens of tuff are composed chiefly of quartz and feldspar crystals, many of which are rounded grains ranging from a few millimeters to more than 1 centimeter in length.

Kunz (1894, p. 692) reported that the matrix of the sapphires found on Rock Creek is an argillaceous slate, but later he stated (Kunz, 1895, p. 599) that the matrix "is identical with that of the Missouri River deposits near Helena, a vesicular mica-augite andesite." Still later he acknowledged that little was known of the source of the sapphires, for he wrote (Kunz, 1901, p. 756) that "an attempt was made to trace some of the gems to their original source in the rock. As to the success of this search no positive results have yet been reported." Pratt (1906, pp. 110-111) wrote as follows regarding the probable source of the sapphires and nature of the sapphire-bearing rock:

No sapphires have as yet been found in place, but a few have been found in the gravels that were embedded in the original matrix. Mr. Knuth, to whom I showed a specimen of the andesite containing sapphires from French Bar, said that it very closely resembled the small fragments of rock carrying sapphires that he had found at Rock Creek. It is not at all improbable that these sapphires ol:iginated in the same type of rock as those of the Missouri River and that small. dikes of andesite will be found in the divide between Myers, Cold, and Quartz Creeks.

The Rock Creek sapphires have not yet been found in place, except perhaps in small fragments of igneous rocks in the gravels as described above. Some of the pyroclastic rock strongly resembles the sapphirebearing dike rock from Ruby Bar, on the Missouri River, and the sapphires may have been derived from the tuff's of the area. Weathering has apparently concentrated them on the benches or flats, from which some have been recovered, as well as in the stream valleys. Many of the sapphires are well-rounded, suggesting abrasion from stream transportation. Some of them may have been derived from the conglomerate associated with the igneous rocks, but their limited distribution suggests a local source, probably the igneous or pyroclastic rocks.

A sample of the discarded concentrate containing small sapphires was examined by Jewell Glass of the U. S. Geological Survey. Miss 
Glass found that the concentrate had the following mineral composition, exclusive of fragments of argillite, sandstone, igneous rock, and quartz:

\begin{tabular}{|c|c|}
\hline & $\begin{array}{l}\text { Percent } \\
\text { by weight }\end{array}$ \\
\hline Corundum (sapphire) & 31 \\
\hline Black pebbles consisting chiefly of manganese oxides.------- & 57 \\
\hline $\begin{array}{l}\text { Brown and red pebbles consisting chiefly of iron oxide and } \\
\text { hydroxides }\end{array}$ & $3+$ \\
\hline Garnet -- & $3+$ \\
\hline Specularite & $3-$ \\
\hline Magnetite & 2 \\
\hline 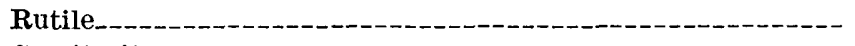 & $0.5-$ \\
\hline
\end{tabular}

The specularite and rutile pebbles are conspicuous because of their brilliant surfaces. The rutile occurs in blockly grains as much as 1 centimeter or more in length; it rarely possesses crystal form. The garnet is dull and inconspicuous. It occurs in fractured irregular grains, rarely in distinct crystals, and none of it approaches gem quality. The color is dark brownish-red, and the composition is probably intermediate between almandite and spessartite as indicated by the index of refraction, 1.815, and specific gravity, 4.25.

\section{SAPPHIRES}

Rock Creek sapphires are similar to those found along the Missouri River except that a wider range of colors is common, and many of the stones are more strongly colored. Weed (1902, p. 281) reported that about 6 percent of the stones mined in the years 1899-1901 were suitable for cutting, but it is doubtful that so large a proportion was classed as gem material in later years. Most of the sapphires are pale in color, some are dull and translucent, and many stones show irregular or zonal distribution of color, with a brightly colored spot near the center of the crystal. Stones with two distinct colors have been called "pinto" sapphires locally (Harstead, 1926, pp. 21-22). The commonest colors are pale blue, blue green, green, pink, and yellow. Blue or blue-green sapphires with a central orange or yellow spot are not rare. Kunz (1901a, p. 449) observed that the Rock Creek sapphires

*** are remarkable for small colored spots, which, when properly cut, change the entire stone to yellow or brown. The red stones found are pale but pronounced rubies, many of them intensely brilliant; the yellows, many tints of brown, blue greens, reds, and other colors are distinct from those found at any other locality, and all of the colors are rendered more brilliant by artificial light. 
In another publication Kunz (1901, p. 757) described the Rock Creek gems in glowing terms as follows:

At no known locality, however, has there ever been found so great a variety of rich colors in corundum gems as here. At the Paris Exposition of 1900, there was shown a brooch of over 200 of these stones, ranging from $11 / 4$ to 3 carats each, every one of a different tint or shade. Although the deep-red ruby and the "velvet blue" or "cornflower" sapphire were lacking, yet the richness and variety of the other kinds were unequaled; pale rubies, pink, salmon, passing into yellow, pure yellow, yellow brown, and deep brown, pale blues and greens, bluegreen, etc. Often a single stone would show two or three distinct shades of one color. Many of the colors have never been observed at any other locality. All were of unusual brilliancy, and improve greatly in artificial light. The butterflies and other rich jewels made from these stones possess almost the beauty of natural insects.

The writer collected a sample of small sapphires from discard piles at the small workshop on Rock Creek where concentrates were cleaned and sized. The stones are about 3 or 4 millimeters in average diameter. The range of color is probably representative of that of typical assemblages of larger stones. The sample was divided into selected color groups and the weight percent of each group determined. Results are tabulated below :

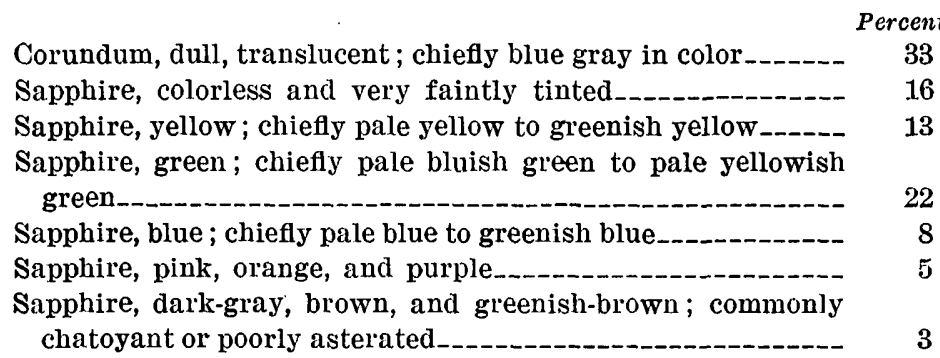

Many of the Rock Creek sapphires, especially the pale and colorless crystals, show distinct chatoyancy. As in the Missouri River sapphires this is due to swarms of minutes cavities usually arranged in lines, which, in each of the six segments of the crystal, parallel the intersection of the bounding prism face and the basal pinacoid. The larger cavities are hexagonal or triangular negative crystals commonly less than 0.005 millimeter in diameter. A few are needlelike. Sapphires with these inclusions are not asterated, but resemble moonstones in appearance. Some of the darker stones, however, possess distinct asterism and might be a source of small star sapphires. They contain innumerable minute, oriented rutile needles which tend to lie parallel to the basal pinacoid and intersect each other at $60^{\circ}$ angles. The rutile needles commonly give the sapphire a brown tint. A few sapphires, chiefly pale lilac in color, contain numerous larger and 
more irregular rutile inclusions, generally less than 0.5 millimeter in length and unoriented.

The Rock Creek sapphires are similar in size and form to those found along the Missouri River near Helena. Some of the crystals are sharp and distinct, with pitted surfaces, others are abraded and rounded. Most of the crystals are hexagonal plates, many are thick enough to be approximately equidimensional, and a few are prismatic crystals with greater length than width. Crystal forms are the same as those commonly developed by the Missouri River sapphires-basal pinacoid, prism, dipyramid, and unit rhombohedron (fig. 8).

\section{HISTORY AND PRODUCTION}

Sapphires were discovered on Rock Creek about 1892 according to Kunz (1893, p. 762) who reported that they were found in a gravel bed 4 feet thick overlain by 3 feet of loam. He wrote that the sapphires "appear to be exceedingly plentiful, from ten to twenty being found in every pan of gravel." Later Kunz (1894, p. 692) stated that the yield was about 60 stones to the pan of gravel. Although it may be doubted that sapphires were so abundant in most of the gravel, the Rock Creek deposit is notable as the only placer concentration in Montana rich enough to have been worked for sapphires alone. About 1894, 75 pounds of sapphires were reported to have been produced from the Rock Creek deposit (Kunz, 1895, p. 599). Extensive mining was done during the summers of 1899 and 1900 by William Knuth, of Helena, and William Moffitt, of Philipsburg, according. to Pratt (1906, p. 110). About 400,000 carats of sapphire was recovered, of which 25,000 carats was fit for cutting. Kunz (1901, pp. 756-757) reported that in 1900 a large number of gems from Rock Creek were cut in Helena, and that the proportion of pink and pale-red stones was greater than before.

At some date prior to 1906 the American Gem Mining Syndicate (also called the American Gem Syndicate), with headquarters in St. Louis, acquired the Rock Creek deposit. The following note, written by W. H. Emmons about 1906, was quoted by Sterrett (1907, p. 1231):

The American Gem Syndicate continued to work its sapphire placers on Rock Creek, about 20 miles southwest of Philipsburg, Mont. A considerable quantity of sapphires was produced. This company has a factory in Switzerland, where the stones are cut to be used as watch jewels and for other bearings.

Most of the 86,000 ounces of industrial sapphire and of the 384,000 carats of varicolored gem sapphires produced in Montana in 1911 (Sterrett, 1912, p. 1065) came from Rock Creek, the remainder chiefly from Dry Cottonwood Creek. Extensive mining was done also in 1912 and 1913 , but activity was more restricted in 1914 . In 1920 the com- 
bined sapphire production from the American Gem Mining Syndicate on Rock Creek and the New Mine Sapphire Syndicate at the Yogo deposits was greater than in any previous year except 1913 (Stoddard, 1923 , p. 216). In the late 20 's production of industrial sapphire from Rock Creek amounted to about 20,000 ounces per year (Kunz, 1928, p. 513). Joe Yob, of Philipsburg, states that American Gem Mining Syndicate was in poor financial condition in 1926 when he was made mine superintendent, but that the situation was improved when several thousand ounces of culls were sold after being cleaned by hydrochloric-acid treatment and gentle abrasion in a small ball mill.

About 1936 the American Gem Mining Syndicate sold its property on Rock Creek to Charles H. Carpp and J. W. Kaiser, of Philipsburg, Mont., who conducted placer operations until 1943. Production in 1936 was 17,200 ounces, valued at about $\$ 25,000$, and all of the sapphires were sold for industrial use (Ball, 1937, p. 1440). In 1937 the production of 21,469 ounces of sapphires worth about $\$ 35,000$ was reported (Ball, 1938, p. 1292), and in 1938, 9,480 ounces, worth about $\$ 11,000$ (Ball, 1939, p. 1387). Average production during the years 1939-43 was probably in excess of 10,000 ounces per year. Most of the 50,000 ounces produced in Montana in 1942 came from Rock Creek (Ball, 1943a, p. 1511). Sapphires produced from this deposit in 1942 were sold to the government and stockpiled for use as instrument jewels. Mining was discontinued in 1943.

Most of the mining was accomplished by hydraulicking the gravels into sluices where the sapphires and other: heavy minerals were retained in riffles. Concentrates from the riffles were cleaned in a small jig;.dried, screened; and sorted by hand. Sterrett (1908, pp. 823-824) observed the operations in 1907 and described the process as follows:

The gravels in both Anaconda and Meyer gulches are sluiced down with small hydraulics. The first part of the sluice is over bed rock and from this portion the boulders and coarse debris are forked out. The finer material is then washed down through board sluices over cross riflles. The latter are removed and cleaned up each day. In Meyer Gulch the tailings from the riffles are carried throngh several hundred yards of wooden sluice to remove the waste from the gulch near the workings. This sluice has riffles with bar's parallel to its length largely to protect the boards of which it is constructed, though partly to catch sapphires that have washed over the cross riffles. The parallel riffles are cleaned up at wide intervals of time. All of the concentrates are further cleaned on a jig operated by a small water wheel. The concentrates from the jig are oven-dried and shipped for picking. Gold is also saved from the concentrates.

The quantity of gold in the sapphire concentrates was apparently almost insignificant, for no attempt was made to recover it in some of the later mining.

Reserves of unworked placers are of undetermined extent, and it is doubtful that they will be worked again on a large scale, for natural 
sapphire has now been largely replaced by synthetic corundum for industrial use. Only a very rough estimate of the quantity and value of sapphire from Rock Creek can be obtained from the incomplete production data available. The total quantity of sapphire produced since 1893 is probably not less than three-fourths of a million ounces, which had, when sold, a value probably in excess of one million dollars.

\section{DRY COTTONWOOD CREEK SAPPHIRE DEPOSIT}

\section{LOCATION}

Dry Cottonwood Creek in Deer Lodge County heads on the Continental Divide about 12 miles northwest of Butte, and it flows westward to join Clark Fork 11 miles south of the town of Deer Lodge (fig. 1). Sapphire mining has been attempted chiefly in the upper 4 miles of the south fork of the creek. Sapphires were found in test panning at the highest spring on this fork of the creek, at an elevation of 6,950 feet.

\section{GEOLOGY}

According to Sterrett (1911a, pp. 882-883) the geologic setting of the placer deposits is simple. Above Grand Pre Flat the upper 2 miles of the south fork of Dry Cottonwood Creek has cut its valley through porphyry of several types probably representing several intrusions; below the flat the country rock is granite or quartz monzonite. Kunz $(1904$, p. 829) records that in June 1902, a Mr. J. M. Jamieson

* * discovered, at the head of the main fork of Dry Cottonwood Creek, the source from which the sapphires of that locality were derived. He [Jamieson] does not state that character of the rock, which is doubtless an igneous dike, but says that it is a ledge some 200 feet wide, traceable for 3,000 feet, and contains sapphires and garnets. Little development has yet been made, the deepest cut being about 8 feet, but $\mathrm{Mr}$. Jamieson proposes to exploit the locality further very soon.

The location of the source of the sapphires by Jamieson has not been verified. In June 1910, Sterrett visited the locality and seached for the sapphire-bearing rock. He wrote as follows regarding his findings (Sterrett, 1916, p. 883) :

The source of the sapphires is not known. Unauthenticated reports refer to both the garnetiferous quartz porophyry and to the granite porphyry in the upper part of Dry Cottonwood Creek valley. A careful examination of the quartzporphyry locality failed to discover any sapphires in place. A tunnel and pits had been made at this place in decomposed porphyry. The material from the openings had slaked to a white crumbling mass. No sapphires were found in panning two buckets full of the slaked porphyry, but only a few garnet fragments and numerous glassy quartz crystals. Many specimens of the granite porphyry from different places along the creek and from the creek gravels were carefully examined for sapphires without success. A more detailed study of the region might discover other types of rock generally considered as a more common home 
of the sapphire. Prospecting for the sapphire matrix may with reason be carried on to an elevation of 7,000 feet on Dry Cottonwood, but the possibility of other bodies of such rock lower down the creek should not be overlooked.

\section{SAPPHIRES}

Sterrett had previously described the sapphires from Dry Cottonwood Creek as follows (Sterrett, 1908, p. 822) :

The larger part of the sapphire, either on account of small size or poor color is suitable for mechanical purposes only, as watch and meter bearings. Some of the sapphires are suitable in size, quality, and color for cutting as gems. The predominant colors of the Dry Cottonwood sapphires are deep and light aquamarine and pale yellowish green. Other colors are clear and smoky blue, light and dark topaz yellow, straw yellow, yellowish green like olivine, light and dark pink; some stones are nearly ruby red, lilac and pale amethystine, and some are colorless. The pleochroism of some of the sapphires is marked, the same crystal appearing greenish when viewed across the prism and blue through its length, or pale and deeper pink, as the case might be. It is not unusual to find aquamarine-colored stones with a pink spot in the center. This combination furnishes an attractive gem when cut. A feature of the deep pink colored sapphires is their rich and beautiful color under artificial light, even when not very attractive in natural light.

The sapphires occur in rough crystals, often with curved faces, as irregular rounded masses, and as waterworn pebbles. The surfaces of those which are not waterworn are very much etched and corroded. One yellowish-green sapphire crystal, weighing a little over $4 \frac{1}{2}$ carats, had very much the shape of a rough diamond crystal. This effect is largely due to the fact that the development of the basal and rhombohedral faces produced a form resembling an octahedron. This apparent octahedral form along with marked curvature of the faces and peculiar etching produces the effect described. The proportion of waterworn sapphires is not large, and only a few show a large amount of wear. A few red and cinnamon-red garnets, mostly small, are found in the concentrates with the sapphires.

\section{HISTORY AND PRODUCTION}

Sapphires are said to have been found here about 1889 (Kunz, 1904, p. 829), but no important work was done in the area until 1907. About 1893 some 25 pounds of sapphires were recovered during a few days' work on a placer deposit, said to extend 2,500 acres, on Dry Cottonwood Creek "about 5 miles east of the mining camp of Champion and on the western slope of the main ridge" (Kunz, 1894, p. 692). Sapphires were apparently well concentrated in the gravels worked at that time, for a yield of "about 30 stones to the pan at Bed Rock, on Cotton wood Creek" was reported. In 1902 the Northwest Sapphire Co. of Butte, Mont., was reported (Struthers and Fisher, 1903, p. 250) to be mining sapphires from the Dry Cottonwood placers by means of a hydraulic. The Variegated Sapphire Co. operated a gold dredge above Grand Pre Flat during the summer of 1907 and for a month in 1908. Gold was recovered in sufficient quantity to pay the cost of operation during only a part of the time. Sapphires also were re- 
covered, but their value was not great enough to make the venture profitable. The operation of the dredge has been described in some detail by Sterrett $(1908$, p. $821 ; 1911$ a, p. 882$)$.

In 1910 the principal claims on the upper part of the creek were held by West Dodd, of Des Moines, Iowa, successor to the Variegated Sapphire Co. Only minor prospecting and placer mining were in progress on the claims at that time. Below Grand Pre Flat a number of claims were held by the Consolidated Gold and Sapphire Mining Co. of Butte, Mont., which operated a dredge in the valley during 1910. Other claims were held by local miners. Consolidated Gold and Sapphire Mining Co. also operated its dredge on Dry Cottonwood Creek in 1911, but after that time no large-scale operations were reported. Interest in the deposit was temporarily revived in 1942 and 1943 when the demand for industrial sapphire increased because of the war, but there was no production. In 1946, Joe Yob, of Philipsburg, Mont., held claims in the area, but neither mining nor prospecting was in progress, and the writer did not visit the locality.

No records of sapphire production from Dry Cottonwood Creek are available, but it is certain that the deposit yielded several thousand ounces of industrial sapphires and a few thousand carats of gem material during the periods of active mining, 1907-8 and 1910-11. Nearly 384,000 carats of varicolored gem sapphires were produced in Montana in 1911, chiefly from Rock Creek and Dry Cottonwood Creek (Sterrett, 1912, p. 1065).

\section{OTHER SAPPHIRE OCCURRENCES}

\section{QUARTZ GULCH}

Quartz Gulch, in Granite County, and the adjacent gulches have yielded a few sapphires from placer deposits. These small valleys drain northeast into Rock Creek and head at the mountain divide north of the Rock Creek sapphire deposit (fig. 1). Pratt (1906, p. 111) noted that a few sapphires had been found on Quartz Creek, and Sterrett (1913, p. 1052) mentioned the occurrence as follows:

Other deposits in Granite County were prospected and worked with good results on a smaller scale by Richard Stingle, of Philipsburg, Mont. These claims lie northeast of those of the American Gem Mining Syndicate across a mountain divide on tributaries of the main prong of Rock Creek. Mr. Stingle claims a large yield of varicolored gem sapphire in proportion to the total quantity mined. The stones range from colorless to greenish-blue, light-green, yellow, orange, pink and nearly ruby-red. Rough stones weighing 7 to 8 carats are found.

\section{POLE CREEK}

Pole Creek, in the northern foothills of the Madison Range in Madison County, drains part of the region between the Elk Creek and Bear 
Trap corundum deposits in the area mapped by the writer (pl. 2). Gravel deposits on Pole Creek were worked for a number of years by A. W. Tanner of Norris, Mont., but the gold content of the gravels was too small to make the operation profitable, and the placer: workings have been inactive for many years. A number of garnet and sapphire gems were recovered from the concentrates, as indicated in the following note by Pratt (1906, p. 116).

Near Norris, Madison County, Mont., Mr. A. W. 'Tanner reports the finding of considerable corundum of gem quality in his concentrates from gold placer mining. One piece of corunduin showing good red and green colors weighed 8 onnces, and one piece of ruby corundum weighed $588 \%$ carats.

'These large pieces of sapphire and ruby corundum were evidently not gem material, for no large cut Montana sapphires or rubies have been described, and no further mention of 'Tanner's finds appears in. the literature. It is most improbable that the gem-quality cortundum found by Tanner was derived from corundum deposits in the Pony gneiss similar to those described in the second part of this report, for: corundum associated with the metamorphic rocks is uniformly dull, translucent or opaque, gray-blue to lilac-colored material. The source of the gem material is probably igneous rocks of the region to the south or southwest, where small dikes of many types are known to occur. The upper part of the valley of Pole Creek is cut into a large deposit of glacial gravels and Tertiary "lake beds." The glacial debris may have been transported considerable distances from the region now drained by Cherry Creek and Spanish Creek, hence the source of the sapphires may lie beyond the present limits of the Pole Creek drainage basin.

\section{BROWNS GULCH}

The first large stream valley northwest of Butte, Mont., is Browns Gulch in Silver Bow County. Upper tributaries of Browns Gulch drain the area immediately south of the headwaters of Dry Cottonwood Creek where sapphires have been mined. (See fig. 1.) Sapphires presumably have been found also in Browns Gulch, for the locality is listed as a potential source by Ball (1943, p. 1519).

\section{Chouteau COUNTY}

The following. note, regarding the discovery of sapphires in Chouteau County, Mont., was written by Kunz (1897a, p. 1202) :

Mr. T. E. Crutcher, of Helena, Mont., reports that sapphires have been found in some abundance and of good size and quality in the northeastern part of Chouteau County, and that a number of claims have been located. The character of the stones found is similar to that of the sapphires from the bars of the Missouri. 
The occurrence of sapphires at this locality has not been verified, but it is reasonable to expect occasional sapphires in the gravels of the Missouri River at any point downstream from the deposits near Helena.

\section{ORIGIN OF THE CORUNDUM IN DIKES}

Corundum in igneous rocks has been usually attributed to one of the following sources: (1) direct crystallization from the magma, (2) reaction between the magma and aluminous inclusions or wall rock, or (3) acquisition from a pre-existing corundum-bearing rock. Sapphires found in dikes in Montana have been ascribed to each of these modes of origin, but very little evidence has been offered in support of any genetic hypothesis.

Of the several suggested modes of origin, that of inclusion of preexisting corundum crystals in the magma is least tenable. At Yogo Gulch thousands of tons of dike rock have been inspected during mining operations, and countless specimens of sapphires embedded in the igneous rock have been collected, but sapphires have not been found in inclusions of older rocks within the dike. Physical properties of the Yogo sapphires offer some evidence that they were not acquired by the magma from older metamorphic rocks. The crystal form of the sapphires and their lack of twinning and parting is unlike that of corundum formed in a metamorphic environment. Further it is hardly reasonable to assume that the Yogo dike could obtain a relative abundance of sapphire inclusions from a subjacent corundum-bearing rock while nearby intrusives remained free of sapphire contamination. The uniformity of distribution of sapphires throughout the narrow dike almost 5 miles long is also difficult to explain if the sapphires are interpreted as foreign inclusions.

Most writers have suggested that the Yogo sapphires were formed by reaction between the magma and aluminous inclusions, either of shale of Paleozoic age, argillite in the Belt series, or older pre-Cambrian metamorphic rocks. Direct supporting evidence, such as corundum in reaction rims about inclusions, is lacking. Several lines of evidence indicate that sapphires were not formed during or after emplacement of the dike. The dike is narrow, and it probably cooled too rapidly to allow extensive reaction; the absence of appreciable metamorphism of limestone walls and fragments is in accordance with this assumption. Sapphires formed by reaction between magma and shales of Paleozoic age in the dike fissure should be distributed erratically like the inclusions themselves. But the sapphires occur uniformly scattered through the igneous rock and are least abundant where the dike is choked with inclusions. Finally, it is evident that the magma was not in equilibrium with corundum during the final 
stages of crystallization, for it attacked and partly dissolved the sapphire crystals, leaving them pitted, etched, and rounded.

Inclusions of quartz-kyanite gneiss observed by the writer in the Yogo dike are surrounded by reaction rims in which feldspar and dark-green spinel are prominent constituents (p. 16). The coating that surrounds the sapphire crystals is chiefly green spinel of the same appearance. Reaction between the magma and the inclusions to form spinel and plagioclase can be illustrated in simplified form by the following equation:

Kyanite and Quartz+Nepheline and Diopside $\rightarrow$ Spinel +Plagioclase $2 \mathrm{Al}_{2} \mathrm{SiO}_{5}+2 \mathrm{SiO}_{2}+2 \mathrm{NaAlSiO}_{4}+\mathrm{CaMgSi}_{2} \mathrm{O}_{6} \rightarrow \mathrm{MgAl}_{2} \mathrm{O}_{4}+2 \mathrm{NaAlSi}_{8} \mathrm{O}_{8}+\mathrm{CaAl}_{2} \mathrm{Si}_{2} \mathrm{O}_{3}$

Quartz has been included in the equation to demonstrate that the presence of free silica in the kyanite-bearing gneiss inclusions would not prevent the formation of spinel or corundum as reaction products. Nepheline and diopside, rather than analcime and diopside, are used to represent the composition of the magma, for the primary feldspathoid in the rock was probably nepheline, which was later converted in part to analcime by deuteric alteration. If the magma was saturated with alumina but not with magnesia at an early stage of crystallization, at least in the vicinity of aluminous inclusions, corundum rather than spinel may have formed as a reaction product. The reaction can be summarized by the equation given below :

Kyanite and Quartz+Nepheline $\rightarrow$ Corundum + Albite $\mathrm{Al}_{2} \mathrm{SiO}_{5}+\mathrm{SiO}_{2}+\mathrm{NaAlSiO}_{4} \rightarrow \mathrm{Al}_{2} \mathrm{O}_{8}+\mathrm{NaAlSi}_{3} \mathrm{O}_{8}$

Reaction at an early magmatic stage to supply sapphire crystals evenly distributed through the magma may thus be postulated to have occurred as a relatively small body of silica-deficient magma invaded a zone of shattered kyanite-bearing gneiss in pre-Belt rocks at considerable depth below the present surface. Reaction also between the silica-deficient magma and other minerals may be suggested to account for the corundum. For example, fragments of ordinary gneisses and schists could supply an abundance of muscovite, which is unstable in igneous rocks similar to the Yogo dike. Reaction between the magma and muscovite would probably be accompanied by the precipitation of corundum or spinel and orthoclase or leucite. Assimilation of calcite or dolomite is widely accepted as a process leading to the development of silica-deficient magmas and rocks, and the assimilation of both calcite and aluminous minerals such as kyanite or muscovite may be suggested as a particularly favorable condition for the development of corundum in igneous rocks.

But it hardly seems necessary to postulate a complex history for the Yogo intrusive in order to account for the minute quality of free alumina contained in the form of sapphires. The separation of 
alumina from some types of silicate melts has long since been demonstrated in the laboratory. Morozewicz (1895, p. 281) obtained crystalline material containing corundum and spinel from silicate melts similar in composition to some igneous rocks. He found that any alumina in excess of the amount required to form feldspar crystallized from the melts as corundum, spinel, or both, depending on the quantity of magnesia available. Corundum has been reported as an accessory mineral in almost innumerable igneous rocks, particularly in feldspathoidal rocks. Lagorio (1895, pp. 285-296) was among the first to note that corundum occurs in small quantities in many types of igneous rocks, including pegmatite, trachyte, basalt, nephelinite, and peridotite. He argued that in most cases it had crystallized from the igneous magma, just as magnetite and the other common accessory oxides originated. The presence of scattered grains of corundum in the analcime-rich dike at Yogo Gulch would have attracted no special interest, had the corundum not been of value as gems. Most of the characteristics of the Yogo sapphires, especially their unique crystal form, uniform distribution, lack of association with inclusions, and uniform color, are adequately explained by the hypothesis of direct crystallization from the magma.

The sapphire-bearing dike at Ruby Bar on the Missouri River yields little data of genetic significance. The igneous rock is so fine-grained that its exact composition cannot be determined. It does not resemble the Yogo intrusive, and the sapphires also differ from the Yogo sapphires, both in color and form. Garnet crystals occur in the igneous rock, and they were observed also as inclusions in one sapphire crystal. The sapphire crystals appear slightly etched, but they are not surrounded by a coating or reaction rim. They are relatively uniform in size and similar in crystal form. Sapphires from the Missouri River deposits are almost identical with those from Cottonwood Creek and Rock Creek, and they are entirely unlike the corundum found in metamorphic rocks in Montana.

\section{CORUNDUM DEPOSITS IN METAMORPHIC ROCKS}

\section{INTRODUCTION}

The only important corundum deposits that occur in metamorphic rocks in Montana are those of Gallatin and Madison Counties, southwest of Bozeman (fig. 1). The origin of the corundum is disputed. By some geologists it has been considered a product of metamorphism; others have thought the corundum-bearing rock to be igneous. The corundum itself is distinctly different from that in the dikes and placer deposits elsewhere in Montana. It is dull in appearance, translucent, blue gray to lilac, and it occurs in larger, elongate crystals. It is suitable only for abrasive use. 
Three deposits have been located and partly developed. They are the Bozeman corundum deposit in sec. 31, T. 2 S., R. 4 E.; the Elk Creek corundum deposit in secs. 22 and 23, T. 3 S., R. 3 E.; and the Bear Trap corundum deposit in sec. 6, T. 4 S., R. 2 E. The first two are easily accessible by roads from the town of Gallatin Gateway. The third can be reached with some difficulty by a ranch road which leaves the Norris-Bozeman road at the east end of the Madison River bridge. Plate 2 shows the location of the deposits and the geology of the area in which they occur.

The Bozeman and Elk Creek corundum deposits are in the northern foothills of the Madison Range at elevations of 5,400 to 6,400 feet above sea level, and the Bear 'Trap corundum deposit is within the margin of the higher, forested mountain country at an altitude of about 7,400 feet. The foothills are open, grass-covered grazing land at the southern margin of the broad basin known as the Gallatin Valley. Near the Elk Creek deposit there are sparse growths of brush and timber, and the larger valleys are used as farmland, especially where irrigation is possible. Grass, sage, and other small plants are abundant at the lower elevations, and aspen and conifers are plentiful in the mountains. Soil cover is well developed, and the less resistant rocks are deeply weathered, so that the bedrock is poorly exposed at the deposits. Winters are often long and severe, and travel in the higher country is impeded by snow. Summer weather, however, is excellent, and Bozeman is the center of a productive farming and ranching region.

\section{HISTORY AND PRODUCTION}

It is reported that Reno Sales, now a consulting geologist of Anaconda Copper Mining Co., identified the corundum on Elk Creek at some date prior to 1900. The Montana Corundum Co. operated the Elk Creek deposit during the period 1901-3 and mined more than 300 tons of corundum-bearing rock. (Pratt, 1902, pp. 885-886.) The company ceased operation in 1903 , and the property remained inactive until 1943. About 1902 the Bozeman deposit was partly developed as the Bozeman Corundum Co. mine (Montana Bur. Agr., Labor, and Industry, 1902, p. 445), but no production is reported. In 1943 Leverett S. Ropes of Helena, Mont., who had been employed as engineer for milling operations of the Montana Corundum Co. in 1901-3, called attention to the Elk Creek deposit as a possible domestic source of corundum during the war. In October 1943 the U. S. Bureau of Mines began exploration of the Elk Creek deposit. Less than a year later part of the property on which the deposit occurs was acquired by Industrial Minerals Corporation, a subsidiary of Ameri- 
can Abrasives Co. The corporation undertook further development work in preparation for mining and made plans for a mill, but in the summer of 1945 , before any corundum concentrates had been produced, the plans were abandoned because of the small size of the known corundum-bearing lenses and the lessened need for corundum after the end of the war in Europe. The Bureau of Mines also explored the Bozeman and Bear Trap deposits in 1944-45, but neither deposit showed as much promise of yielding corundum as the Elk Creek deposit.

\section{GEOLOGY}

\section{REGIONAL GEOLOGY}

The corundum deposits near Bozeman, Mont., occur in the preCambrian metamorphic rocks of the northern part of the Madison Range. The deposits are near the center of the Three Forks quadrangle, the general geology of which has been presented by Peale $(1896$, no. 24$)$ in the Three Forks folio. The geologic setting of the deposits is shown in greater detail on the accompanying geologic map (pl. 2).

The metamorphic rocks of the region are varied in texture and composition. They include schist, gneiss, quartzite, and marble, although no marble occurs in the immediate vicinity of the corundum deposits. All of these rocks were folded, severely metamorphosed, and intruded by numerous pegmatite dikes during pre-Cambrian time. Following this the region was eroded deeply; and eventually Cambrian sandstones and younger Paleozoic sedimentary rocks were deposited over the beveled pre-Cambrian surface. Younger; less metamorphosed pre-Cambrian rocks of the Belt series are found elsewhere in Montana between the highly metamorphosed gneisses and the Cambrian sedimentary rocks, but they are absent in the northern part of the Madison Range.

Remnants of the Paleozoic rocks are preserved in two northwestsoutheast trending structural troughs which separate the three areas of metamorphic rocks in which the corundum deposits occur. Each belt of Paleozoic rocks is essentially a tilted wedge of beds resting in normal contact with the underlying gneiss at its southwest margin and bounded to the northeast by a vertical or steeply dipping fault. The Paleozoic formations in the area range in age from Cambrian to Permian, but they are not subdivided on the geologic map "(pl. 2).

The metamorphic and the sedimentary rocks have been intruded by small dikes, sills, and small irregular masses of andesite porphyry, periodotite, and other igneous rocks (pl. 2).

The foothills of the Madison Range disappear northward under an extensive accumulation of poorly consolidated Tertiary "lake beds," 
which consist chiefly of mixed clastic and pyroclastic material. Remnants of the lake beds can be found within the mountainous area in the broad upper valleys of Pole Creek and Elk Creek, and along Cherry Creek north of Elk Mountain (pl. 2). Lake beds surround the low hills in which the Bozeman corundum deposit is located. Recent alluvium and talus blend with the margins of the poorly consolidated Tertiary "lake beds," and all three are grouped together on the geologic map. Pleistocene glacial deposits and Recent alluvium obscure the bedrock geology in the broad upper valley of Cherry Creek, known as Cherry Creek basin.

\section{METAMORPHTC ROCKS}

\section{GENERAL DESCRIPTION}

The pre-Cambrian metamorphic rocks in which the corundum deposits occur were called the Pony series by Tansley and Schafer (1933, pp. 8-9). The texture and composition of the rocks are highly varied; quartzite layers alternate locally with zones of hornblende gneiss, feldspar-mica granulite and other varieties of metamorphic rocks. For convenience the term gneiss is used loosely in the remainder of this report to include rocks that range in fabric from schistose gneiss rich. in mica to coarse-grained granulite composed chiefly of quartz and. feldspar. Some of the gneiss is strongly layered; other parts of it are dense, unbanded rock with determinable lineation, but indistinct foliation. Each type of metamorphic rock grades locally into other types, and an area mapped as hornblende gneiss, for example, commonly includes thin beds of quartzite and layers of light-colored feldsparrich gneiss.

Minerals usually found in the gneiss are the feldspars, hornblende, quartz; the micas, and garnet. More restricted in occurrence are rutile, chlorite, vermiculite, corundum, sillimanite, magnetite, tourmaline, and other minerals.

\section{MAJOR TYPES}

Despite the intimate and varied mixture of rocks of different types in the metamorphic complex, certain varieties are sufficiently distinctive or abundant to merit further description. They include quartzite, hornblende gneiss, feldspar-rich gneiss similar in composition to granite, sillimanite-corundum gneiss with associated border zones of: vermiculite gneiss, and minor occurrences of iron-rich gneiss.

Most of the quartzite is colorless, light brown, or white, and very coarsely crystalline. In hand speeimens it is not readily distinguishable from some types of vein quartz. Typical material is composed of irregular interlocking quartz crystals a few millimeters to several centimeters in diameter, with no more than traces of other minerals. 
Pale-green muscovite was observed in the quartzite at a few localities. Layers of quartzite range in thickness from less than xin inch to more than 100 feet, but in general they are 3 to 15 feet thick. Many quartzite layers ean be traced for several hundred feet, but others are short and lenticular. 'Contacts between gneiss and quartzite are generally sharp, although the quartzite is gneissic locally and grades into quartzrich gneiss. Quartzite generally weathers less readily than adjacent gneiss and forms ridges that dominate the outcrops, especially in the vicinity of the Bozeman and Elk Creek cor undum deposits.

The presence or absence of quartzite layers was selected as the chief basis for subdivision of the metamorphic complex into major units for mapping purposes in the vicinity of the corundum deposits. Gneiss in which the quartzite occurs is generally dark-colored and rich in hornblende, whereas that which lacks quartzite is dominantly light-colored and rich in feldspar. Included with the light-colored gneiss in the areas devoid of quartzite are numerous zones of dark hornblende gneiss, the distribution of which is indicated by the line pattern on plate 2. The hornblende gneiss in these layers is generally similar to that with which quartzite occurs.

Hornblende gneiss is the most abundant type of metamorphic rock in the immediate vicinity of the corundum deposits. The average mineralogic composition of samples of hornblende gneiss from all three deposits is approximately as follows: 30 percent hornblende, 40 percent sodic plagioclase, 20 percent quartz, 5 percent garnet, 2 percent chlorite, and traces of sphene, orthoclase, apatite, rutile, zircon, and ilmenite. The chemical composition of a channel sample across $21 / 2$ feet of hornblende gneiss below the corundum-bearing rock at the Bureau of Mines sample locality no. 18 (pl. 4) is given by the following analysis made by Glen Edgington of the Bureau of Entomology and Plant Quarantine for the U. S. Geological Survey :

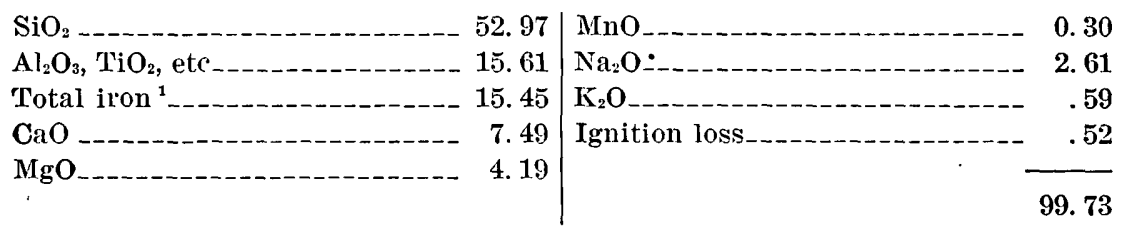

${ }^{1}$ Reported as $\mathrm{Fe}_{2} \mathrm{O}_{3}$.

Some of the hornblende gneiss contains as much as 90 percent hornblende, but such material is very limited in distribution. Other varie-ties contain less than 15 percent hornblende, and grade into biotitequartz-feldspar gneiss. Garnet is conspicuous in only a small fraction of the hornblende gneiss.

Typical hornblende gneiss is a compact granular rock without conspicuous layering or schistosity. Hornblende occurs as elongated 
prismatic crystals generally 1 to 2 millimeters wide and 4 to 10 millimeters long in a mosaic of smaller equidimensional grains of guartz and plagioclase. The hornblende crystals show a strong tendency toward common orientation; petrofabric analysis, of one section showed a concentration of more than 75 percent of the c-axes in 5 percent of the area of a Schmid net on which they were projected.

Irregular patches of strongly layered, coarse-grained hornblende gneiss are commonly associated with the nonlayered gneiss, especially where small pegatites are numerous. Nearly half of the hornblende gneiss shown on the maps of the Bozeman and Elk Creek corundum deposits (pls. 3 and 5) is of the layered type. Although the layered gneiss may have been formed in part by the injection of thin sheets and dikes of light-colored pegmatite into dark gneiss, it is more likely that the layering developed by segregation of pre-existing light and dark minerals into layers under the influence of pegmatitic fluids, for the composition of the coarse layered gneiss is not greatly different from that of the associated fine-grained gneiss. The irregular: distribution of the strongly layered gneiss is attributed to unequal penetration into the rocks by the solutions which facilitated reorganization and coarsening of the minerals.

Although light-colored feldspar-rich gneisses are probably the most abundant metamorphic rocks of the region, they were not examined in detail, for the corundum deposits are restricted to the large zones of dark gneiss in which quartzite layers are common. Most of the light-colored gneiss is pink to gray, faintly layered, fine- to mediumgrained, and granular. It consists chiefly of microcline, sodic plagioclase and quartz, and, except for the layering, much of it resembles granite. Fine-grained hornblende occurs in the dark layers of some varieties, others contain biotite and muscovite. Garnet is a common accessory, and at a few localities it is a major constituent of the lightcolored gneiss.

Corundum-sillimanite gneiss and closely associated sillimanite gneiss occur in narrow zones in the quartzite-bearing gneiss. Corundum has been found in only three areas, which are described in greater detail in a later section of this report. The corundum-bearing rocks of the three deposits are similar, although within the limits of each deposit there is wide variety in texture, associated minerals, and corundum content of the rock. The corundum occurs in lenticular and tabular bodies of white or gray rock composed chiefly of feldspar, mica, and sillimanite. The lenses range from a few inches to 6 feet in width and from a few feet to more than 800 feet in length. All. of the bodies of corundum-bearing rock are parallel to the foliation. and to major compositional layering of the gneiss. The thicker: parts of the bodies commonly are coarse-grained or pegmatitic, but other 
parts of the rock are schistose. The main corundum-bearing layer in the Elk Creek deposit and many of the smaller lenses in all three deposits are enclosed in a thin envelope of friable, dark-colored gneiss. Vermiculite is usually the most abundant mineral in the friable gneiss, and it occurs in some of the rock in flakes as much as an inch in diameter. Other constituents of the vermiculite gneiss are feldspar, garnet, and, rarely quartz or corundum.

Iron-rich gneiss occurs at a number of localities (pl. 2) both in the quartzite-bearing gneiss and in the quartzite-free areas. At most of the occurrences the iron-rich rock consists of hematite with guartz and chalcedony. Prospect pits have been dug in many of the ironrich outcrops, but all of the deposits appear to be small. Thin sections of samples from seven of the deposits were examined in order to determine if corundum occurs in the rocks, but none was observed. It is not apparent whether the concentrations of iron originated as sedimentary deposits or were introduced at a later time.

\section{STRUCTURE}

The foliation of the gneiss generally coincides with the strike and dip of quartzite layers where they are present. The map (pl. 2) presents a simplified and generalized picture of the attitude of the metamorphic rocks in the vicinity of the corundum deposits. Many symbols on the map are an average of several measurements, and some of the gneiss is so tightly folded and crumpled that determination of attitude is impossible.

Except in the northeastern part of the area the quartzite-bearing gneiss forms a broad central belt wisth fairly uniform strike and generally steep dip (pl. 2). The major fault in the west-central part of the area does not appear to interrupt the continuity of the quartzitebearing zone. Exposures of the main quartzite zone or zones are limited to three small areas in the northeastern part of the area. The northernmost of these, in which the Bozeman corundum deposit is located, probably continues eastward and then southward beneath the cover of lake beds to connect with the southernmost area around the nose of a steeply tilted anticlinal fold. If so, the thin layer of corundum-sillimanite gneiss at the south end of the southern quartzite area can be correlated with the Bozeman corundum zones to the north, and probably also with the Elk Creek corundum horizon west of the fault. 'The same quartzite belt may continue westward from the Bozeman deposit to join the two narrower belts of quartzite at the western margin of the mapped area, but the continuity is uncertain, for the only exposures between the two areas are devoid of quartzite.

At the Bozeman corundum deposit small isoclinal folds were observed in the gneiss, many quartzite beds thicken and end abruptly, 
and the numerous corundum-bearing layers cannot be projected with assurance from trench to trench. (See pl. 5.) The V-shaped outcrop pattern of the quartzite 160 feet southwest of the south end of trench 21 is unquestionably due to folding, and the thick lenses of quartzite were probably formed by repetition and thickening of thinner layers during the folding. The large number of corundum-bearing layers exposed in some of the trenches and the existence of two major corundum zones at this deposit may also be due to duplication by folding.

The banding and small-scale folding in some outcrops of hornblende gneiss at the Bear Trap corundum deposit disclose a complex local variation from the present regional structure of the metamorphic rocks. An early set of contorted bands of gneiss with distinct alinement of mineral constituents is transected by a later set of fractures and a superimposed crude foliation. The superimposed fractures and foliation parallel the major structure of the metamorphic rocks as disclosed by the trend of ridges of hornblende gneiss and the attitude of nearby quartzite beds.

\section{IGNEOUS ROCKS}

Igneous rocks of the area fall into two classe's: (1) pegmatites, which were emplaced during metamorphism of the pre-Cambrian sedimenntary rocks and are therefore found only in the metamorphic rocks, and

(2) younger igneous rocks of varied composition which occur as dikes and sills in both the metamorphic rocks and the Paleozoic sedimentary rocks. Occurrences of both types are shown on plate 2. Only the larger pegmatites were mapped; mall dikes and stringers of pegmatite abound in nearly all parts of the gneiss.

\section{PEGMATITES}

The pegmatites are coarse-grained, light-colored dikes and stringers composed chiefly of quartz, perthite, sodic plagioclase, and muscovite. A few contain tourmaline, apatite, and less common minerals. The quartz in some of the pegmatites is rose colored, and a few of the dikes grade into rose quartz and barren white quartz veins. Larger pegmatites are more numerous near the Bear Trap deposit and far-: ther west. Several have been prospected for mica, fergusonite, and other minerals, especially in the pre-Cambrian rocks beyond the Madison River. At the three corundum deposits the pegmatites are usually small, irregular, and poorly exposed. Only at the Bear Trap deposit (pl. 6) were they shown on the detailed map.

It is conceivable that the pegmatites were formed by the same process that was suggested for the origin of the small pegmatite-like layers in the banded gneiss-that is, from components already pres- 
ent in the rocks, mobilized during the intense regional metamorphism and transferred only short distances. But the pegmatites are locally so abundant and in some cases so unrelated in composition to the enclosing gneiss, that a process of metamorphic segregation appears less adequate as an hypothesis of orgin than derivation at greater depth from a granitic magma formed during the process of regional metamorphism.

\section{YOUNGER IGNEOUS ROCKS}

Peale (1896) mapped numerous occurrences of igneous rocks in the Three Forks quadrangle. Of these, only a few small dikes and irregular intrusives occur in the immediate vicinity of the corundum deposits. None of these has any genetic connection with the corundum, therefore they are described only briefly in the paragraphs which follow.

An andesite(?) porphyry dike, 5 to 10 feet wide, is poorly exposed on the hillside above the adit at the Bear Trap corundum deposit (pl. 6). The rock is pale gray green on fresh exposures, and weathers reddish brown. Although the dike is altered and deeply weathered, the rock exhibits a distinctly porphyritic texture both in hand specimens and under the microscope. The phenocrysts are dark, needlelike crystals of altered amphibole(?) and cloudy gray crystals of altered feldspar which average 1 to 3 millimeters in length. The matrix is a felted mass of colorless, elongate crystals (feldspar ?), in which apatite crystals are common. Quartz is rare or absent.

A dike of peridotite also is exposed at the Bear Trap deposit (pl. 6 ). Boulders of this rock are heavy and strongly magnetic. The peridotite is banded; its chief minerals are augite, olivine, spinel, magnetite, and possibly chromite. The dike varies in thickness from a few feet to more than 10 feet. Associated with it are layers of gneiss rich in large garnet crystals, chlorite, limonite, and orthorhombic pyroxene. A small dike of similar peridotite crops out about $11 / 2$ miles southeast of the Bear Trap deposit, and a larger sill of peridotite about 100 feet wide and nearly a mile in length is well exposed about 2 miles due west of the Elk Creek deposit (pl. 2).

In adit 2 of the Elk Creek corundum deposit (pl. 4) irregular dikes of dark greenish-brown, fine-grained, nonporphyritic basalt occur along small faults in the metamorphic rocks. The basalt is severely fractured and altered, but several minerals can be identified under the microscope. Augite crystals make up about one fourth of the rock; labradorite is slightly less abundant; and part of the fibrous secondary minerals probably resulted from the alteration of olivine.

A small body of diabase crops out about a mile southwest of the west end of the Elk Creek deposit in NW1/4 sec..28, T_3 S., R. 3 E., 
and a small body of extrusive basalt is preserved 2 miles south of the Bozeman deposit in sec. 7, T. 3 S., R. 4 E. A thin sill of hornblende andesite porphyry can be traced for almost 2 miles in the Paleozoic sedimentary rocks east and southeast of the Elk Creek deposit. Smaller igneous intrusives shown on plate 2 include a sill of andesite(?) about half a mile long in sec. 4, T. 3 S., R. 3 E.; an isolated knob of phonolite in sec. 2 of the same township; a small 'dike of hornblende trachyte in sec. 24, T. 2 S., R. 3 E.; another of basalt in sec. 27 ; and a very small exposure in sec. 13, T. 2 S., R. 3 E. of a coarsely crystalline white rock composed almost entirely of oligoclase associated with green and brown serpentine (?) and chert.

\section{METALLIFEROUS DEPOSITS}

Ores of gold, silver, and other metals occur in veins and mineralized fractures in the porphyritic igneous rocks and adjacent metamorphic rocks about 10 miles north of the Bear Trap corundum deposit, and similar mineral deposits are numerous in the region west of the Madison River. Only a few pits have been dug by prospectors along iron-stained fractures and quartz veins in the metamorphic rocks near the corundum deposits. The metallic mineral deposits of the region are younger than the corundum-bearing rocks and are probably related genetically to some of the younger igneous rocks.

\section{DESCRIPTION OF THE CORUNDUM DEPOSITS}

Detailed descriptions of the three abrasive corundum deposits are presented in an economic report (Clabaugh and Armstrong, 1951) published by the U. S. Geological Survey. A condensed description of each of the deposits is given below, and the reader is referrerl to the economic report for additional information on distribution, size, continuity, and corundum content of the lenses of corundum-bearing rock.

\section{ELK CREEK DEPOSIT}

The Elk Creek corundum deposit has been known by many names. It is commonly called the "Montana mine" as a result of early operations of the Montana Corundum Co. The U. S. Bureau of Mines used the name "Gallatin deposit." The names "Fuller corundum mine" and "Industrial Minerals Corporation property" were later applied to the part of the deposit controlled by American Abrasives Co. The remainder of the deposit is owned by Flying D Ranges, Inc., and has been called by that name. The name "Elk Creek deposit" is widely known and is perhaps the least confusing designation for the corundum deposits in secs. 22 and 23, T. 3 S., R. 3 E.

The geologic setting of the deposit is shown on plate 2 and the general nature of the metamorphic rocks has been discussed. The 
outcrop map of the Elk Creek deposit (pl. 3) shows that ridges and knobs of quartzite are the type of rock most widely exposed at the surface, but the trenches indicate the abundance of gneiss. All of the gneiss has been grouped under the term "hornblende gneiss" on the map, because hornblende is commonly the most prominent mineral in the foliated rocks although the mineral composition is highly varied. Stringers and dikes of pegmatite are numerous, but they are generally so small and poorly exposed that they are not shown on the map.

The largest body of corundum-bearing rock in the Elk Creek deposit is the lens in which the workings of the old Montana mine are located. It was further explored by the U. S. Bureau of Mines shaft and drift and by Industrial Minerals Corporation adit 1. The approximate outline of the lens and the location of the workings are shown on the map and longitudinal projection (pl. 3). The underground workings of the Montana mine have caved since the property was abandoned in 1903. Map of the accessible underground workings and sample data of the Bureau of Mines are given in plate 4. Between adit 1 and the northeast end of the old mine workings the main lens of corundum-bearing rock has a minimum length of 800 feet, a vertical extent of about 50 feet, and an average width of approximately 2 feet. The average corundum content is probably not less than 10 percent by weight. No other body of corundum-sillimanite gneiss in the three deposits approaches this lens in size. It is a tabular body essentially parallel to the foliation of the enclosing hornblende gneiss and to the nearby beds of quartzite. No layers of quartzite were observed in direct contact with the corundum-bearing rock. A thin irregular zone of vermiculite gneiss generally borders the hard corundum-bearing rock. The corundum-bearing rock narrows rather abruptly at its lower margin, corundum decreases in abundance, and the rock grades into one or more wedge-shaped "tails" of garnet-biotite-plagioclase gneiss.

The typical corundum-rich rock is a medium-grained gneiss streaked or spotted with aggregates of coarse crystals (figs. 10 and 11). The coarsely crystalline aggregates consists of euhedral, gray-blue corundum crystals and white to cream-colored perthite. Crystals vary in length from less than a tenth of an inch to several inches, and corundum crystals a foot long have been reported. Biotite is generally absent from the coarsely crystalline part of the rock, but large flakes of biotite surround corundum in a few specimens. Biotite is commonly most abundant at the margins of perthite and corundum aggregates. Grains of rutile are included in the margins of nearly all of the corundum crystals. Scattered crystals of corundum with aureoles or halos of perthite give some specimens a pseudoorbicular structure. 


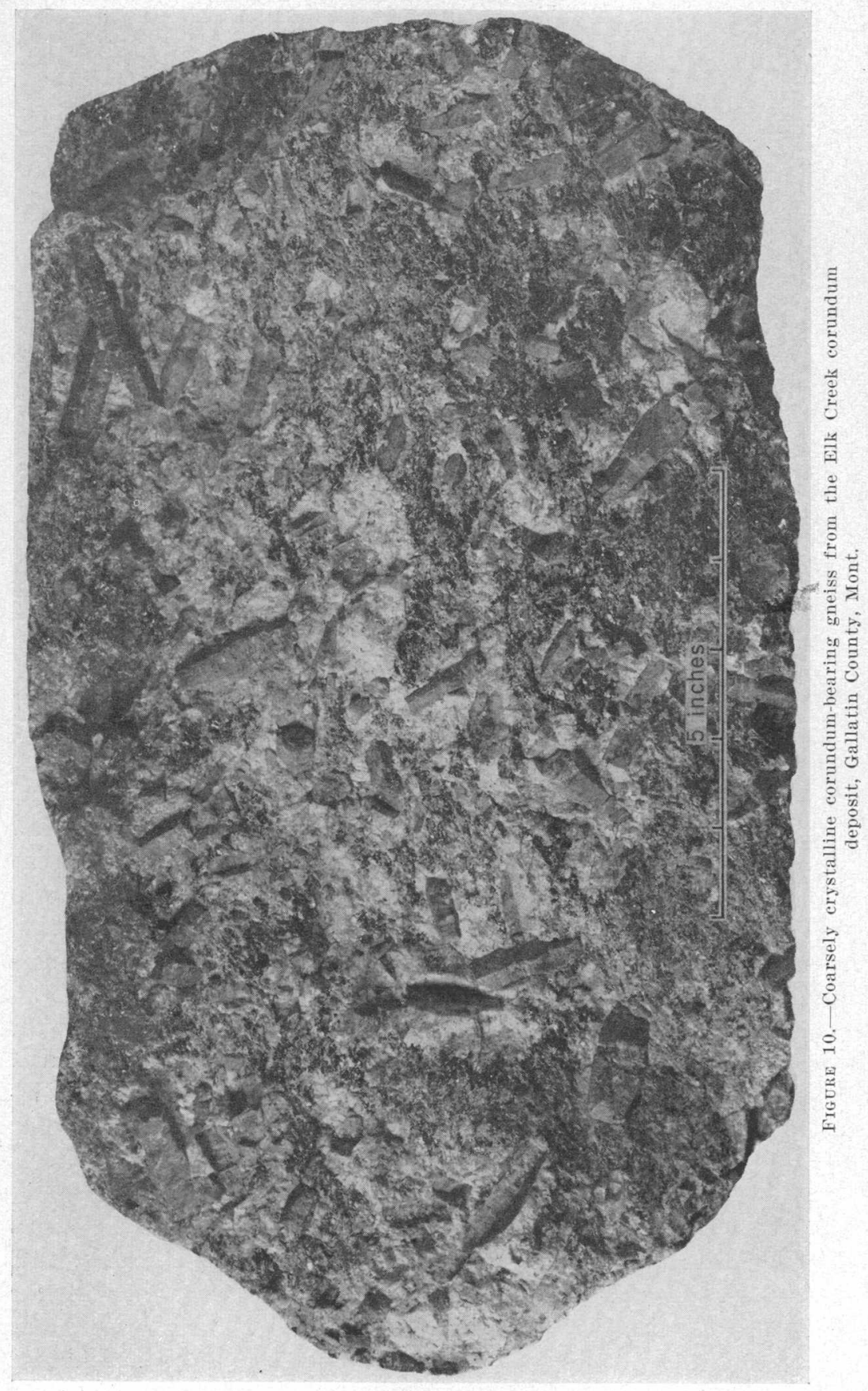




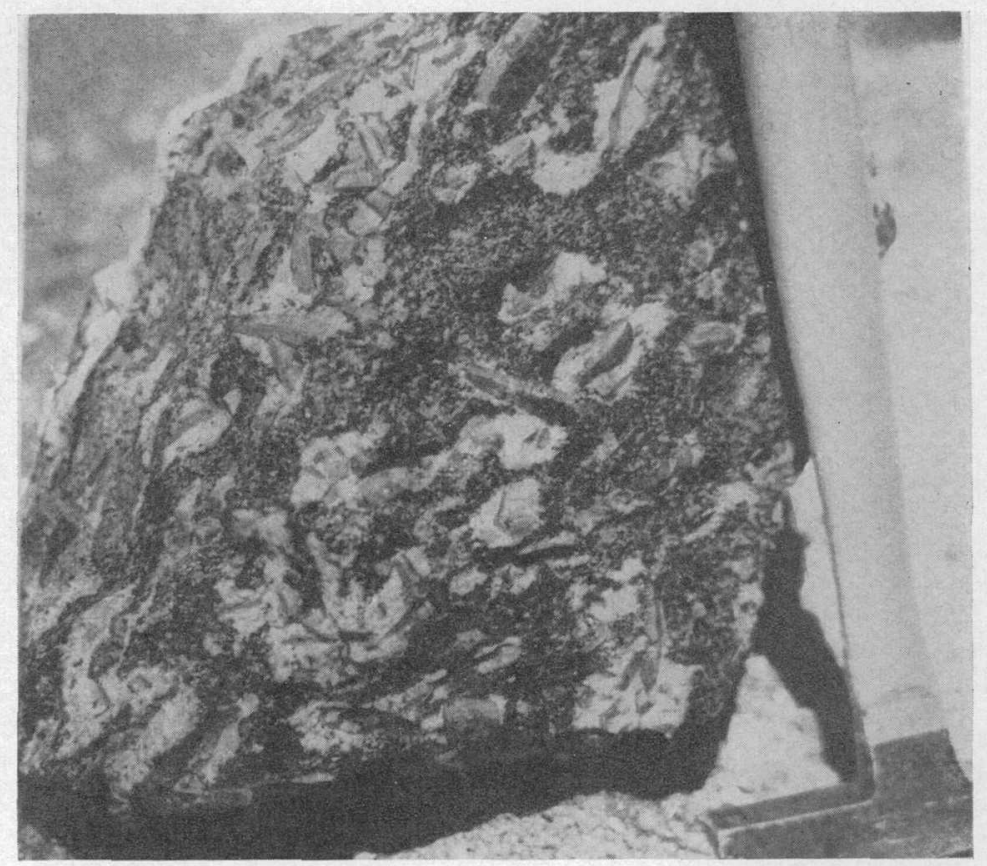

Figure 11.-Corundum-bearing gneiss showing an abundance of coarsely crystalline aggregates of corundum and feldspar in medium-grained corundum-sillimanite-biotite-feldspar gneiss, Elk Creek corundum deposit, Gallatin County, Mont.

The islandlike masses or irregular stringers of coarse crystals occur in finer-grained gneiss composed of biotite, plagioclase, microcline, perthite, corundum, sillimanite, and muscovite, all as crystals a few millimeters or less in length. Some of these fine-grained minerals can be distinguished only under the microscope. Plagioclase (albite to oligoclase) and biotite are the most abundant minerals of the gneiss, and together they usually constitute from 40 to 75 percent of the finergrained corundum rock. Microcline and perthite are locally abundant in the fine-grained rock, but perthite is most abundant in the coarse aggregates of crystals. Corundum is present in many small grains and platy skeletal crystals, many of which partly enclose adjacent feldspar crystals. Sillimanite occurs in fibrous bundles of fine acicular crystals, commonly intergrown with biotite. Muscovite is less abundant than biotite, but it is the dominant mica in some specimens. Among the minerals that occur in smaller amounts are rutile, sphene, zircon, apatite, tourmaline, and magnetite. Rogers (1912, pp. 54-56) reported that baddeleyite occurs in association with the rutile. Secondary minerals formed by alteration of the gneiss include sericite and other alteration products of feldspar, and a fine fibrous or platy mineral of high birefringence (probably sericite) to which corundum has partly altered. Alteration of the corundum crystals along fractures and twinning planes is common, even in unweathered 
samples, but the process of alteration evidently has not gone far enough to impair the abrasive efficiency of the corundum.

The border zone of vermiculite gneiss which separates the cor undumbearing rock from the adjacent hornblende gneiss in the Bureau of Mines shaft ranges from 2 to 12 inches in thickness and has an average thickness of about 4 inches. The vermiculite gneiss is invariably loose and friable, and small pegmatitic stringers of quartz and feldspar are more numerous in the border zone than in the nearby hornblende gneiss. Vermiculite is the most conspicuous mineral, but not always the most abundant mineral in the friable gneiss. It occurs in darkbrown flakes which range in diameter from a few millimeters to several centimeters. The mineral expands rapidly on heating and yields water freely; it is optically negative; it has variable indices of refraction with $\beta$ and $\gamma$ generally near 1.58 , and optic angle variable from $0^{\circ}$ to about $20^{\circ}$. Associated minerals include feldspar, quartz, garnet (spessartite-almandite), apatite, hornblende, and rarely corundum. Small crystals of hornblende are most common in the vermiculite gneiss near the hornblende gneiss, and corundum grains were observed only adjacent to the corundum-sillimanite gneiss.

Chemical analyses of the corundum-bearing rock and the vermiculite gneiss from the main lens of the Elk Creek deposit are given below. Material for sample 1 was collected by cutting a channel sample across the 2.6-foot thickness of corundum-sillimanite gneiss at U. S. Bureau of Mines sample locality no. 18 in the southwest drift from the Bureau exploratory shaft (see pl. 4 for sample location), and material for sample 2 was collected from the 6 -inch layer of vermiculite gneiss below the corundum-bearing rock at the same locality. The material for sample 3 is a composite of samples of the vermiculite-rich zones at the top and bottom of the corundum-bearing layer taken at 10-foot intervals along the total length of the southwest drift. The three analyses were made by Glen Edgington, of the Bureau of Entomology and Plant Quarantine, U. S. Department of Agriculture.

\begin{tabular}{|c|c|c|c|}
\hline & Sample 1 & Sample 2 & Sample 3 \\
\hline $\mathrm{SiO}_{2-.}$ & 46. 98 & 52. 98 & 51. 32 \\
\hline $\mathrm{A}_{2} \mathrm{O}_{3}, \mathrm{TiO}_{2}$, etc $\ldots$ & 35.55 & 20. 63 & 19. 55 \\
\hline Total iron reported as $\mathrm{Fe}_{2} \mathrm{O}_{3}$ & 6. 14 & 13. 35 & 14. 98 \\
\hline $\mathrm{CaO} \ldots$ & .94 & 2. 39 & 2. 80 \\
\hline $\mathrm{MgO}_{2}$ & 1. 72 & 3. 35 & 3. 54 \\
\hline $\mathrm{MnO}$ & .13 & .23 & .25 \\
\hline $\mathrm{Na}_{2} \mathrm{O}$ & 2. 99 & 4. 53 & 4. 00 \\
\hline $\mathrm{K}_{2} \mathrm{O}$ & 4. 26 & 1. 15 & 1. 34 \\
\hline \multirow[t]{2}{*}{ Ignition loss } & .78 & 2. 35 & 2. 58 \\
\hline & 99. & 100.96 & 100 . \\
\hline
\end{tabular}

Smaller bodies of corundum-bearing rock at the Elk Creek deposit are similar in general to the large lens described above, except that 
coarse-grained corundum-bearing rock is less common and the average corundum content is lower. Some of the thinner layers exposed west of adit 1 are composed chiefly of feldspar, muscovite, and sillimanite, with less than 5 percent corundum. The rock is lighter in color, softer, and more altered, and the vermiculite border is abcent or poorly developed in many places.

Fragments of sillimanite-cor'undum gneiss are found in the dimp of a caved pit 1,400 feet northeast of the old main shaft of: the Mantana mine. The rock was not observed in place, and no other occurrences of sillimanite or corundum were observed between the old mine workings and the cover of younger sedimentary rocks which rest on the gneiss about three-fourths of a mile northeast:

Southwest of the main corundum lens, adits, trenches, and pits have been dug along approximately the same horizon for a distance of more than 5,000 feet (pl. 3). Most of these workings have uncovered one or more thin layers of sillimanite gneiss containing a few percent of corundum. The rocks exposed in the trench beside adit 2 and in adit 3 are complexly folded, broken, and locally intruded by irregular dikes of basalt (pl. 4). The Sunset shaft and the drifts from it follow two or three layers of sillimanite gneiss, the thicker parts of which contain several percent corundum. The average width of ithe corundum-bearing layers exposed underground and in the nearby trenches is only a few inches: The two trenches at the extreme southwest end of the mapped area (pl. 3) expose one to three layers of sillimanite gneiss and garnet-sillimanite gneiss. Only one layer, a few inches thick, contained visible crystals of corundum.

About a mile southwest of the Elk Creek deposit sillimanite gneiss crops out near the small diabase intrusive in the NW1/4 sec. $28, \mathrm{~T} .3 \mathrm{~S}$, R. $3 \mathrm{E}$. The sillimanite gneiss occurs as a layer more than 4 feet thick which weathers to yield large, hard boulders at the surface. The rock has a spotted and banded appearance! due to the abundance of stringers and irregular augenlike clusters of quartz and plagioclase crystals. Sillimanite occurs in radial fibrous clusters a few millimeters to several centimeters in diameter, and large irregular crystals of ganinet are scattered through the rock. Microscopic examination reveals that the stringers of quartz and plagioclase commonly have a micropegmatitic texture, with the two minerals in subgraphic intergrowth or with quartz replacing plagioclase in a myrmekitic pattern. Some of the larger plagioclase crystals are zoned with cores of andesine and margins of sodic oligoclase. Adjacent to the quartz-feldspar intergrowths sillimanite is extensively replaced by fine-grained aggregates of biotite, muscovite, chlorite, ilmenite(?), and feldspar. Sillimanite and andesine occur in contact without an intervening reaction border, but sillimanite and quartz are invariably separated by the fine-grained aggregates. The ragged margins of partly replaced silli- 
manite crystals are clouded with swarms of minute grains of a colorless, isotropic(?) mineral, possibly garnet, which has a high index of refraction. A few irregular grains of zircon are associated with the sillimanite; rutile is abundant; pyrite and sphene are present, but corundum is absent.

\section{BOZEMAN DEPOSIT}

The Bozeman corundum deposit is on a low ridge of pre-Cambrian rocks which projects through a cover of Tertiary "lake beds" about 5 miles northeast of the old Montaria corundum mine (pl. 2). The deposit was developed by five shallow shafts and two adits in 1902, when it was known as the Bozeman Corundum Co. mine. No production is recorded, and the workings were abandoned after the Montana mine was closed in 1903.

The geology of the Bozeman deposit is similar to that of the Elk Creek deposit. Thin lenticular layers of cor undum-bearing rock occur in pre-Cambrian gneiss that contains numerous beds of quartzite. Natural exposures of the gneiss are few; only the thicker layers of quartzite and the harder zones of horriblende gneiss crop out. Corundum-bearing layers'decurr in two bëts or zones. 'The sonthern zone (trienches 1 to 16 , pl: "5) is "separated from the rorthern zone (trenches 17 to 29) by several hundred feet of barren "gneiss and quartzite. Several layer's of corundum-bearing gneiss occur in each zone. The distribution, thickness, and corundum content of these layers is shown on the mäp; plate 5 , which includes sample data of the U. S. Bureau of Mines. Corundum-bearing rock of the Bozeman deposit differs little from the smaller bodies at the Elk Creek deposit. The average corundum "content of the richest body is less than 6 peicent, and no layer is as much as 2 feet thick. 'Most of the corundumbearing rock is dense, hard, and gray, and is composed of feldspar, muscovite, biotite, alld ififror amounts of sillimanite, gray-blue corundhim, and rutile. ":The relative abundance of constituent minerals differs greatly from place to place. "Corindum crystals from"adit 2 'and from the old pits between the adit and trench 21 are lilac or rose "gray. Although they have béeñ called rubiês; they are trót of gem quality. The texture of the cortundium-bearing rock in the Bozeman deposit varies from fine-grainety and equigranular to coarsegrained, approaching pegmatitic texture. However, very little of the corundum rock is as coarse-grained as that in the Elk Creek deposit, and aureoles of feldspar about corundum are not so common. Corundum-bearing layers are generally only a féw' inches thick, and many of them are bordered by thin zones of friable, vermiculite-rich gneiss.

A small occurrence of corundum was discovered by the witer about 4 'miles south of the Bozeman deposit (pl. 2) in 'sec. 20, T.' 3 S., 
R. 4 E. At this locality the hornblende gneiss and quartzite are strongly folded and contorted adjacent to the major fault along which pre-Cambrian metamorphic rocks are in contact with limestone of Paleozoic age. The corundum occurs as numerous small platy crystals in a layer of light-colored gneiss about 6 inches thick. The gneiss contains considerable sillimanite and muscovite, and it resembles some of the thin corundum-bearing layers in the Elk Creek and Bozeman deposits.

\section{BEAR TRAP DEPOSIT}

The Bear Trap corundum deposit is in high mountain country at the northern margin of the Gallatin National Forest about 10 miles southwest of the Elk Creek deposit. It is reached by car over a dirt road approximately 9 miles long, which branches from the NorrisBozeman road at the east end of the Madison River bridge. Unimproved ranch roads also give access from Pole Creek (pl. 2). The Bear Trap deposit was largely undeveloped prior to the exploratory work of the U. S. Bureau of Mines in 1944-45.

A few differences between the geology of the Bear Trap area and that of the other two areas have been mentioned. Quartzite is much less abundant; outcrops of hornblende gneiss are more prominent; and pegmatites are larger and more continuous, although they are not especially abundant in the immediate vicinity of the corundumbearing rocks. The dikes of andesite porphyry and peridotite have been described in the section on igneous rocks. Several varieties of gneiss are distinguished on the map of the Bear Trap deposit (pl. 6). A very fine-grained, dense gneiss crops out near the northern edge of the mapped area. It consists chiefly of garnet, hornblende, and feldspar in grains less than half a millimeter in diameter. Light-colored gneiss, similar in composition and appearance to a granite, but strongly foliated, was mapped at a few natural exposures and in the trenches. But here as at the other deposits, most of the gneiss is characterized by an abundance of hornblende and is mapped as hornblende gneiss although it varies in composition from almost pure hornblende rock to hornblende-garnet-quartz gneiss and hornblende-feldspar gneiss.

Two discontinuous layers of corundum-bearing rock were located at the Bear Trap deposit. Exploratory work failed to disclose either an eastern extension of the northern layer or a western extension of the southern layer, and the two are interpreted as segments of a single unit offset approximately 300 feet by a north-trending fault (pl. 6). Most of the corundum-bearing rock in the deposit differs from that in the main lens at the Elk Creek deposit. The corundum content of the rock is generally lower, and sillimanite is far more abundant, constituting 35 to 68 percent by weight of some samples. (See Bureau of Mines sample data on plate 6.) Muscovite is the most abundant mineral in part of the corundum-bearing rock; biotite is uncommon. 
The vermiculite border zone is generally absent. Most of the corundum crystals are irregular and filled with inclusions, although a few large, euhedral crystals can be found.

The largest body of corundum-bearing rock at the Bear: Trap deposit is the lens explored by the Bureau of Mines adit and winze (pl. 6). It is approximately 50 feet long, 5 to 6 feet thick near the center, and about 15 feet or less in vertical extent. The lens is elongate, and it plunges about $20^{\circ} \mathrm{NE}$. The average corundum content is 6 to 7 percent by weight, and the average sillimanite content is about 5 percent. The chief mineral constituents are muscovite, perthite, and sodic plagioclase; other minerals present in small quantity are biotite, rutile, magnetite, pyrite, apatite, and zircon. Corundum crystals range in size from microscopic grains to large prismatic gray crystals more than an inch long. Only an occasional crystal is free of inclusions, and even the large crystals tend to have irregular outlines. Muscovite and feldspar are the minerals commonly included in the corundum, which is partly altered to sericite. Aureoles of perthite around corundum are poorly developed, and very little of the rock has a coarse, pegmatitic texture like that of the coarse-grained corundum-bearing rock at Elk Creek.

Other lenticular layers of corundum-bearing rock were uncovered by exploratory work at the Bear Trap deposit, but they are much smaller than the lens described above, and many trenches failed to disclose any trace of corundum or sillimanite (pl. 6). The layers of corundum-bearing rock near the road intersection are of especial interest because samples from this area (nos. 10-26) show a reciprocal relation between the corundum content and the sillimanite content of the rock. Samples 11, 24, 25, and 26 contain considerable sillimanite but very little corundum; whereas the other samples contain little or no sillimanite but considerable corundum. About 600 feet east of the road intersection a series of short trenches and an old pit expose a layer of sillimanite gneiss about 50 feet long and 0.5 to 2 feet thick. Two samples from the gneiss contain 4 to 6 percent corundum and 56 to 68 percent sillimanite. On the dump of the old pit are a few fragments of dense, hard, gray rock composed entirely of sillimanite and a ninor amount of rutile intergrown with an opaque black mineral.

\section{OTHER OCCURRENCES}

Pratt (1906, p. 133) reported that the Anceny corundum deposit, 5 miles west of the Elk Creek deposit, was being developed in 1906, but in 1944 and 1945 it could not be located, and no one in the area knew of its existence. Ray Woodriff of Montana State College found a loose piece of corundum-bearing rock near the northwest corner: of sec. 16, T. 1 N., R. 6 E. in the foothills of the Bridger Mountains north of Bozeman. Gneiss and marble beds of the Cherry Creek group 
crop out in that area, and kyanite occurs in some of the hornblendegarnet gneiss, but corundum has not been observed in place. Winchell (1914, p. 148) described an occurrence of corundum associated with contact-metamorphosed limestone near Bear Gulch in the Tobacco Root Range. Heinrich (1950a) recently discovered deposits of corundum associated with marble and biotite schist of the Cherry Creek group near the Crystal Graphite mine southeast of Dillon. A. W. Tanner found pale-colored, transparent, industrial and gem sapphires in placer workings on Pole Creek, between the Elk Creek and Bear Trap deposits. This type of corundum in other placer deposits in Montana is derived from igneous rocks rather than from pre-Cambrian metamorphic rocks, and the sapphires in Pole Creek are probably from a similar source. Corundum probably occurs elsewhere in Montana in metamorphic rocks, but other localities have not yet been reported.

\section{ECONOMIC IMPORTANCE OF THE DEPOSITS}

The main lens in the Elk Creek corundum deposit is the largest and richest body of corundum-bearing rock in the three deposits southwest of Bozeman. Corundum mining from the main lens proved unprofitable in 1901-3, and production was evidently considered economically impractical in 1945 when Industrial Minerals Corporation abandoned plans for exploitation of the deposit. Exploration has been adequate to demonstrate that this lens includes several thousand tons of rock containing about 10 percent corundum.

A large tonnage of rock containing 5 percent or less corundum undoubtedly occurs in the Bozeman deposit and in the smaller bodies of the Elk Creek deposit, but it is chiefly in discontinuous layers 6 inches or less in average width. The known volume of corundumbearing rock in the Bear Trap deposit is negligible.

Under emergency conditions the corundum deposits of Gallatin and Madison Counties might be worked to produce about 1,000 tons of abrasive corundum at high cost. Even with the discovery of additional deposits of the same type, the area could supply only a small fraction of the corundum normally required by industries in this country.

The recovery of sillimanite from the corundum-bearing rock has also been considered. The average corundum-bearing gneiss in the Bozeman deposit contains less than 5 percent sillimanite; that in the Elk Creek deposit 5 to 25 percent; and some of the rock in the Bear Trap deposit as much as 68 percent. Examination under the microscope shows that most of the sillimanite is intimately intergrown with biotite and muscovite, and concentrates of sillimanite were found to have a high iron content. 
Further exploration in the vicinity of the three known deposits of abrasive corundum will undoubtedly extend the areas in which corundum is known to occur, and it may disclose new lenses of corundumbearing gneiss, but corundum-bearing bodies appreciably larger and richer than those already known are not likely to be found. Beclrock exposures are so poor that extensive trenching and underground work are necessary for satisfactory exploration.

\section{ORIGIN OF THE CORUNDUM DEPOSITS}

\section{A GENETIC CLASSIFICATION OF CORUNDUM DEPOSITS}

Corundum occurs in a wide variety of rocks and owes its existence in different types of deposits to different genetic processes. Some of the possible modes of origin are outlined below in a brief genetic classification. Mechanical concentrations of corundum, for example sapphires in alluvial deposits, have been omitted from the tabulation.

Three major genetic types of corundum deposits indicated in the classification are igneous, hydrothermal, and metamorphic. A few examples of deposits that have been assigned to each of the major genetic classes are mentioned below.

$"$

Modes of origin of primary corundum deposits

I. Igneous

A. Inclusion of foreign corundum in magma.

B. Reaction between magma and inclusio:is.

C. Direct crystallization from a magma with high alumina-silica ratio owing to :

1. Assimilation of alumina-rich or silica-deficient rocks (ultrabasic rocks, limestonë, alumina-rich shale, etc.).

2. Unusual composition of primary magma or unusual path of differentiation of uncontaminated magma.

II. Hydrothermal

A. Deposition from hydrothermal fuid with high alumina-silica ratio owing to:

1. Reaction' with alumina-rich or silica-deficient wall rocks.

2. Original composition of hydrothermal fluid.

B. Metasomatic changes involving alumina supplied by either the wall III. Metamorphic rock, the hydlothermal fluid, or both.

A. Contact metamorphism.

1. Thermal metamorphism of alumina-rich rock.

2. Pyrometasomatic changes involving alumina supplied by either the invading solutions, the country rock, or both.

B. Regional metamorphism.

1. Dynamic metamorphism of alumina-rich rock.

2. Dynamothermal metamorphism of alumina-rich rock with little or no transfer of material.

3. Extreme dynamothermal metamorphism involving transfer of material. 


\section{EXAMPLES OF CORUNDUM .DEPOSITS IN OTHER REGIONS}

Sapphires occur in rock which is unquestionably igneous at Yogo Gulch and near Canyon Ferry, in Montana. Whether they formed by direct crystallization, reaction, or were merely accidental inclusions has already been considered (pp. 56-58). Corundum occurs in igneous rocks at many other localities. It has been found in a pegmatite in Colorado (Finley, 1907, pp. 479-484), and many of the major corundum deposits of the world, for example those of eastern Canada, South Africa, and the southern Appalachian region of the United States, have been described as corundum occurrences in igneous rocks, notably in association with ultrabasic and with feldspathoidal igneous rocks. However it is not universally accepted that the corundumbearing rocks in these regions actually crystallized from magmas.

Barlow (1915, pp. 35-40) described the extensive corundum-bearing rocks and closely associated nepheline syenites of Ontario as igneous intrusives developed by differentiation from granite of the Laurentian series. He noted, but did not explain, the association of the corundum and nepheline rocks with crystalline limestones of the Grenville series. Corundum occurs in three roughly parallel and widely separated bands, the largest of which has a length, with interruptions, of about 103 miles and a maximum width of almost 6 miles. The corundum-bearing rocks are of varied composition, ranging from syenite and syenite pegmatite through nepheline-rich rocks to essexite, ijolite, and anorthosite. They are characterized by great diversity of composition within short distances and by pronounced foliation parallel to the structure in the adjacent granite gneisses. Barlow concluded that the banded structure of the rocks was acquired while the mass was in a molten or partly consolidated state and that the varied rocks in the complex were derived from a single highly aluminous magma.

Moyd has recently restudied the Ontario corundum-bearing rocks and concluded that they are not of simple igneous origin, but are migmatites formed from pre-existing rocks of the Grenville series. $\mathrm{He}$ attributed the development of such unusual minerals as corundum and nepheline to the abundance of marble and paucity of siliceous rocks in the Grenville. Moyd (1946, p. 201) summarized his interpretation of the origin of the complex as follows:

The genetic sequence would be first, the intrusion of granitic masses into the silica-poor Grenville terrain. These for the most part would crystallize normally, giving rise to usual siliceous pegmatites and emanations and granitizing the gneissic country rocks. However, some of the magma would react with the dolomitic marbles, releasing emanations rich in carbon dioxide. These emanations, while traversing the silica-poor country rocks would lose much of their silica, forming granitic and syenitic migmatites and finally, impoverished in silica, would form more unusual migmatites. These mineralizer-rich emana- 
tions could convert the high lime feldspars of the dark gneisses to alkali feldspars, releasing alumina to form nepheline or corundum, and lime to produce the ubiquitous pockets of calcite, accompanied by fluorite, apatite, sphene, scapolite, and other minerals containing lime in combination with mineralizers.

The association of cortundum-bearing rocks with nepheline syenite has been described from a number of other localities, notably in Russia and India.

But more common than the occurrence of corundum deposits with feldspathoidal rocks is the association with silica-deficient rocks of a different type. Dikes and veins of plagioclase and corundum are enclosed in ultrabasic rocks such as peridotite, serpentine, and pyroxenite in many parts of the world. Lawson (1904, pp. 219-229) called attention to a dike of this nature in Plumas County, Calif., and named the rock plumasite.

DuToit (1918, pp. 53-73) described occurrences of aplitic plumasite in Natal, South Africa. The corundum-bearing dikes consist of oligoclase, a little orthoclase, and corundum, which is generally concentrated near the center of the dike. Margarite is commonly associated with the corundum and a few of the dikes consist chiefly of these two minerals. The country rock in which the dikes occur is a series of basic schists, granulites, and gneisses that were intruded by large sills of ultrabasic rocks now converted to serpentine. Where the feldspathic dikes occur in the metamorphic rocks they are normal quartz-orthoclase pegmatites, but where they enter serpentine, they change to narrow, irregular corundum-plagioclase aplites. Immediately adjacent to each of the corundum aplites the serpentine is altered to a layer of brown flaky mica (vermiculite?) ; next is an outer layer of talc. DuToit observed that the alteration zone contains more silica than the unaffected serpentine, and the corundum-aplite less silica than the normal pegmatite, therefore he concluded that the corundum-bearing rocks originated through desilication of normal pegmatites that intruded and reacted with serpentine.

Hall (1920, pp. 191-200) proposed a similar origin for the pegmatitic corundum-feldspar and corundum-margarite rocks in the extensive and economically important corundum fields of northern and eastern Transvaal. ' The typical corundum-bearing rock, which Hall called plumasite pegmatite, consists of coarsely crystalline white plagioclase (oligoclase or andesine) and dirty-gray or greenish corundum in poorly formed crystals. A few of the larger dikes exhibit a transition from quartz-feldspar pegmatite to corundum-plagioclase rock, and one lenticular dike contains kyanite in addition to cor undum. The dikes are generally bordered by thin irregular layers of dark micaceous material which also occurs as irregular layers in many of the dikes. Adjacent to this micaceous envelope the enclosing ultra- 
basic rock is altered to fibrous and flaky talcose material that contains sillimanite at a few localities.

Larsen (1928, pp. 398-433) reviewed the problem of origin of corundum-bearing dikes and related sodic plagioclase dikes in ultrabasic rocks and rejected the hypotheses of igneous origin and origin by desilication of pegmatites proposed by DuToit, Hall, and others. He summarized the evidence opposed to the desilication of pegmatites as follows (Larsen, 1928, pp. 420-421):

1. The width of the reaction zones is greater than we are accustomed to see and is greater than we would expect.

2. The mineral assemblages of the reaction zones are those of hydrothermal origin rather than of magmatic origin.

3. The minerals of the pegmatites are not such as would be expected from the desilication of a pegmatite or the reaction of a pegmatite with an ultrabasic rock.

4. The amount of material that must be removed from a pegmatite to make an albite rock or an albite corundum rock seems excessive.

5 . There is no relation between the width of the border zones and the width of the albitite or plumasite.

6. The material added to the border zone is quantitatively very different from the material taken from the pegmatite.

7. Some of the pegmatites associated with the plumasites are later than the plumasites.

As an alternative to the theories of igneous origin, Larsen suggested that the deposits

*** were formed as high temperature veins and replacements, probably approaching pegmatite or hydrothermal contact metamorphic deposits in their condition of temperature and concentration. For such deposits the solutions are conceived as moving along channels and depositing, either in the channels or in the adjoining wall rock only a part of their material and at the same time taking up some material from the wall rock and carrying it away.

The character of the deposits indicates that the solutions were rich in alumina and alkalis, relatively poor in silica, and poor in magnesia, lime, iron, and heavy metals. Larsen further suggested that the solutions may have been derived from the ultrabasic magma or a related deep-seated magma.

The corundum deposits of the southern Appalachian region of this country, like those of South Africa, are found in close association with ultrabasic rocks. The peridotites, dunites, pyroxenites, and related rocks are intrusives in metamorphic rocks such as biotite gneisses, amphibole schists, and quartz schists. The greatest concentrations of corundum are found in peripheral veins or dikes located along contacts between the peridotites and country rock. Similar but smaller veins occur in the main bodies of some of the peridotites, and a little corundum is found disseminated in metamorphic rocks and in altered peridotite. 
Despite the rarity of corundum as an accessory mineral in the peridotites and its common occurrence in veinlike masses, Pratt and Lewis (1905, pp. 344-353) advanced the theory that it formed by direct crystallization from the peridotite magna, and that it was concentrated near contacts because crystallization of the peridotite began there, and corundum was one of the first minerals to crystallize. More recently, Hadley (1949, pp. 103-128) presented evidence that the vein deposits in the Buck Creek area are of hydrothermal origin as suggested by Larsen. For the disseminated corundum in amphibolite Hadley (1949, p. 120) suggested a different origin as follows:

The disseminated corundum in the edenite-amphibolite appears to have resulted from concentration of alumina originally contained in the plagioclase of the troctolite. The first step in this process was the development of the coronas along the boundaries between grains of plagioclase and olivine in the troctolite. In this stage, an intergrowth of spinel and amphibole apparently replaced part of the plagioclase, producing a relative concentration of alumina in the mineral spinel $\left(\mathrm{MgO} \cdot \mathrm{Al}_{2} \mathrm{O}_{3}\right)$. In the second stage, the spinel was destroyed as aditional amphibole (edenite) was formed, and the excess alumina from the spinel was deposited as corundum.

Corundum is not uncommon in metamorphic rocks of many types; it occurs in schists and gneisses at almost innumerable localities (Barlow, 1915, pp. 192-285; Pratt, 1906, pp. 50-61), and it has even been found in slates (Anderson and Chesley, 1931, pp. 103-112). Both ordinary corundum and emery occur in contact-metamorphic aureoles developed in aluminous rocks and limestones adjacent to igneous intrusives.

An example of sillimanite schist converted to corundum-bearing quartz-muscovite rock by contact metamorphism has been reported by Ball (1908, pp. 38-40). He summarized the history of the rock as follows:

Sillimanite formed during the recrystallization of the gneiss, a process long antedating the intrusion of quartz monzonite. Since the corundum-bearing rock, however, contains no sillimanite, it is probable that the corundum was produced at the expense of silimanite, quartz being simultaneously formed.

Other occurrences of corundum in metamorphic rocks in Colorado were mentioned recently by Heinrich and Griffitts (1947, p. 1192). Thin basal plates of corundum occur in sillimanite schist near the contact between metamorphosed Leadville limestone and a mafic igenous rock in the vicinity of the old Calumet Iron mine, and barrel-shaped crystals of corundum occur in a zone of chlorite rock in muscovite-garnet and quartz-biotite schists. The corundum may have developed in the sillimanite schist as a consequence of contact metamorphism. The chlorite rock is thought to be a hydrothermal product. 


\section{ORIGIN OF THE DEPOSITS IN SOUTHWESTERN MONTANA}

\section{HYPOTHESIS OF IGNEOUS ORIGIN}

An igneous origin for the corundum deposits in the metamorphic rocks southwest of Bozeman, Mont., was implied by Pratt (1906, pp. 48-49) and by Rogers (1911, pp: 748-751), each of whom called the corundum-bearing rock a syenite. Unfortunately neither of these men had observed the Montana deposits in the field. Therefore, they based their accounts on specimens of the rock and incomplete descriptions of field relations. More recently Heinrich (1949, pp. 307-335) studied the deposits and concluded that they are pegmatites. He pictured the crystallization and alteration of the sill-like bodies as follows:

The large euhedral corundum crystals were the first to form, precipitated from a magma with an excess of aluminum. Within the immediate vicinity of these phenocrysts the concentration of aluminum was therefore reduced, and biotite could not crystallize. Thus the ovoids consist only of potash feldspar. Minute skeletal corundum crystals continued to develop throughout the period of matrix crystallization and do not have the haloes. Post-crystallization solutions rich in aluminum locally converted microcline to muscovite and biotite and microcline to sillimanite.

The coarsely crystalline corundum-perthite rock from Montana unquestionably resembles coarse-grained syenite or pegmatite. The deposits have several additional characteristics in common with other corundum deposits for which an igneous origin has been proposed. They occur as tabular bodies (sills rather than dikes in this case) composed chiefly of feldspar and corundum; they are found only in dark-colored amphibole-rich portions of the metamorphic complex; and they are bordered by irregular vermiculite-bearing alteration zones. The similarity of these deposits to the South African and some of the southern Appalachian occurrences is, therefore, striking.

But the resemblance is only superficial. The hornblende schist actually contains more silica than either the corundum-bearing rock or the vermiculite reaction zone. Therefore abundance of alumina and corresponding deficiency of silica in the Montana corundum-bearing rocks cannot be attributed to desilication by reaction of magma with wall rocks during emplacement as suggested by Hall and DuToit for the African dikes. Dikes of corundum-plagioclase rock in the Transvaal and in Natal are highly irregular; they branch into numerous apophyses and cut through the basic rocks in all directions. Some of the Ontario corundum pegmatites also cut across the banded structure of the corundum and nepheline syenites, and the North Carolina veins or dikes occur both as peripheral bodies and branching, veinlike masses within the periodotites. The Montana corundum-bearing rock, however, is restricted to simple tabular and lenticular bodies essentially 
concordant with the foliation of the enclosing metamorphic rocks and parallel to nearby quartzite beds. Some have a remarkably uniform thickness for lengths of hundreds of feet. Indeed, it is noteworthy that at not one of more than 150 exposures where they were observed do the corundum layers cut across the foliation and banding of the enclosing gneiss or enclose fragments of the wall rock.

The complete absence of inclusions and cross-cutting relations hardly seems compatible with igneous origin, as the writer has pointed out in his discussion (Clabaugh, 1950, pp. 254-257) of Heinrich's hypothesis. Heinrich acknowledges that the corundum-bearing bodies are essentially conformable, but he does not consider this relationship to be evidence against pegmatitic origin of the deposits, for conformable igneous intrusives are common in foliated rocks. He (Heinrich, 1950, p. 378) explains the conformable structure as follows:

Pegmatites utilize whatever planes of weakness are available, and with great depth, where fracturing cannot be supported, wall rock foliation commonly is the only guiding structure available. Structural control of the emplacement of some of the larger corundum sills was afforded by contacts between dissimilar rock types, as for example between quartzite and hornblende gneiss.

However, the granite pegmatites, to which Heinrich considers the corundum "pegmatites" closely related, are not confined to foliation surfaces. Many of them cut across the foliation with marked discordance. Furthermore, none of the larger corundum-bearing layers and few if any of the smaller are in direct contact with quartzite as if emplaced along contacts between dissimilar types of rock. Heinrich (1949, pp. 316-317) described the relation between granitic pegmatites and corundum-bearing syenitic "pegmatites" in the Bozeman region as follows:

With the syenitic pegmatites a few granitic pegmatites are closely associated. They contain quartz, microcline, sodic plagioclase, and green muscovite as the main constituents and as accessories, biotite, garnet, schorl, and blue apatite; small vugs contain muscovite crystals. In the Elk adit at the Gallatin deposit a two-foot pegmatite grades from syenitic (with corundum and sillimanite) to granitic and back to syenitic within a strike length of 80 feet.

Corundum-bearing rock grades into corundum-free feldspathic rock at other localities in the three deposits, especially at the Bozeman. deposit where corundum is rare in many of the layers. The corundumbearing rock also grades into corundum-free, sillimanite-garnet gneiss: at several exposures. About a mile southwest of the Elk Creek deposit in sec. 28 , T. 3 S., R. 3 E. the only alumina-rich rock exposed alongthe strike of the layers is a quartz-sillimanite-garnet gneiss. Heinrich's description implies a genetic relation between the granite pegmatites and the cormundum rocks, but the association can also be attributed to the intersection of granite pegmatites with pre-existing- 
aluminous metamorphic rocks accompanied by the development of intermediate hybrid rock consisting chiefly of perthitic feldspar. Such intersections may be observed in the drift from the Bureau of Mines shaft and in the winze from adit 1 at the Elk Creek deposit. Some of the granite pegmatites are clearly younger than the corundum-bearing rock. Adit 2 at the Bozeman deposit exposes a granite pegmatite emplaced along a small fault that cuts directly across the corundumbearing layers. Here, as at other exposures, the finer-grained portions of the corundum-bearing rock have a gneissic fabric, whereas the granite pegmatite exhibits no preferred orientation of mica or other minerals.

The chemical composition of the corundum-bearing layers can be duplicated more readily in sedimentary rocks than in igneous. This is not surprising, for highly aluminous sedimentary rocks are not uncommon, whereas corundum-bearing igneous rocks are rare and their composition is markedly different from that of common igneous rocks. In table 2 the composition of the corundum-sillimanite rock from the Elk Creek deposit is compared with that calculated by Rogers (1911, p. 750) for similar material (exceptionally rich in corundum) from the Bozeman deposit and with analyses of corundum-bearing igneous(?) rocks from other regions. Accurate calculation of the norm from analysis $I$, table 2 , is impossible, for all the iron was determined as $\mathrm{Fe}_{2} \mathrm{O}_{3}$, whereas both ferrous and ferric iron undoubtedly occur in the rock. On the assumption that half of the iron should appear in the analysis as $\mathrm{FeO}$, calculation of the norm yields the values given in column $\mathrm{A}$ below. Column $\mathrm{B}$ is the norm calculated by Rogers for his sample from the Bozeman deposit.

A

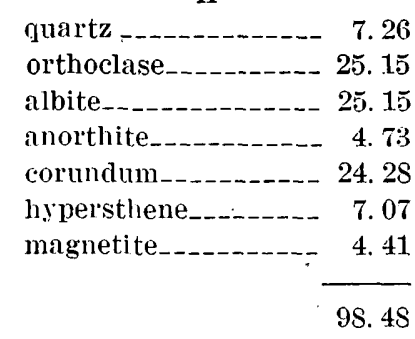

B

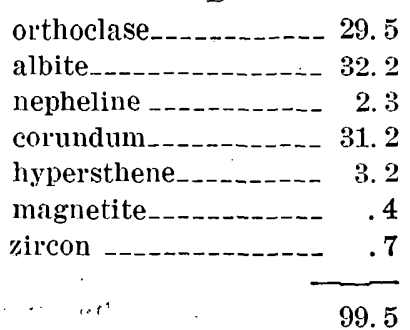

If a greater proportion of ferrous iron is assumed to occur in the Elk Creek rock, a larger amount of hypersthene and less magnetite will appear in the norm. The iron and magnesium actually occur chiefly in biotite, rather than in hypersthene and magnetite, and quartz does not occur with corundum in the rock. If the quartz and corundum are recalculated as sillimanite and corundum, the resulting proportions, 19.60 percent sillimanite and 11.93 percent corundum, approximate those observed in the rock. 
TABLE 2.-Analyses and calculated chemical composition of corundum-bearing rocks thought to be of igneous origin

\begin{tabular}{|c|c|c|c|c|c|c|}
\hline & I & II & III & IV & $\mathrm{v}$ & VI \\
\hline $\mathrm{SiO}_{2}$ & 46.98 & 44.1 & 51.80 & 55.45 & 40.53 & 30.25 \\
\hline $\mathrm{Al}_{2} \mathrm{O}_{3} \ldots$ & & 43.7 & 35.39 & 26. 10 & 48.24 & 57.90 \\
\hline $\mathrm{TiO}_{2} \ldots .$. & 35.55 & & & .30 & & .10 \\
\hline \multicolumn{7}{|l|}{$\mathrm{Fe}_{2} \mathrm{O}_{3}$} \\
\hline $\mathrm{FeO} \ldots$ & 6.14 & .9 & & .49 & .04 & 1.25 \\
\hline $\mathrm{MnO}$ & .13 & $\ldots$ & . & .01 & & ......... \\
\hline $\mathrm{CaO}_{\ldots}$ & .94 & & 4. 54 & 3.65 & .67 & 2. 10 \\
\hline MgO... & 1.72 & .7 & & .13 & & 10 \\
\hline $\mathrm{K}_{2} \mathrm{O} \ldots$ & 4. 26 & 5.0 & & 1.62 & 5.92 & 2. 10 \\
\hline $\mathrm{Na}_{2} \mathrm{O} \ldots \ldots$ & 2.99 & 4.3 & 6. 82 & 9.31 & 3. 40 & 3. 00 \\
\hline $\mathrm{ZrO}_{2} \ldots$ & & .5 & & & & \\
\hline $\mathrm{P}_{2} \mathrm{O}_{2} \ldots$ & ... & & & .01 & & $\mathrm{Tr}$. \\
\hline \multicolumn{3}{|l|}{$\mathrm{CO}_{2}$} & & .88 & & \\
\hline \multicolumn{7}{|l|}{$\mathrm{H}_{2} \mathrm{O}$} \\
\hline \multirow[t]{2}{*}{ Ignition Loss. } & .78 & & 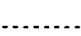 & - & $\ldots . . .1$ & 1.05 \\
\hline & 99.49 & 99.7 & 100.00 & 100.40 & 100.00 & $99.90+$ \\
\hline
\end{tabular}

I. Corundum-bearing rock, Elk Creek deposit, Gallatin County, Mont. Analysis by Glen Edgington, U. S. Dept. Agr., Bur. Entomology and Plant Quarantine.

11. Corundum-bearing rock, Bozeman deposit, Gallatin County Mont. Composition calculated from mineral content. Reported by A. F. Rogers in Jour. Geology, vol. 19, p. 750.

111. Plumasite, Spanish Peak, Plumas County, Calif. Composition calculated from mineral content. Reported by A. C. Lawson in University of California, Dept. of Geology Bull., vol. 3, p. 227.

IV. Raglanite (oligoclase-nepheline-corundum rock), Craigmont, Ontario. Analysis by M. F. Connor. Reported by A. E. Barlow in Canada Geol. Survey Mem. 57, p. 78.

V. Corundum pegmatite, Craigmont, Ontario. Analysis by M. F. Connor. Reported by A. E. Barlow, Canada Geol. Survey Mem. 57, p. 89.

VI. Corundum-bearing dike, Blydschap, Transvaal, Analysis by McCrae. Reported by A. L. Hall in Union of South Africa Geol. Survey Mem.. 15, p. 80.

The texture of the corundum bearing rock is highly varied. Typical corundum-rich rock in the main part of the Elk Creek deposit has been described as a medium-grained gneiss streaked or spotted with aggregates of coarse crystals. Individual specimens range from coarse-grained corundum-feldspar rock to fine-grained sillimanite schist with traces of corundum, biotite, and other minerals. Corundum crystals as much as a foot long have been found in the coarse-grained rock, and aureoles of feldspar surrounding corundum are common. Heinrich accounts for the range in size of crystals by the assumption that the large euhedral corundum crystals developed first, like phenocrysts in a porphyry, followed by potash feldspar which formed shells around the corundum and finally by the much finer grained matrix.

Heinrich's explanation ignores the gneissose to schistose fabric of most of the matrix. It also fails to suggest conditions under which corundum-bearing pegmatites might crystallize at great depth to develop large phenocrysts in a much finer grained matrix, while adjacent and related granitic pegmatites became coarsely crystalline throughout. 
Perhaps the development of the matrix with its gneissic character and local abundance of sillimanite can be attributed to metamorphism of pre-existing corundum pegmatites. If so, a greater problem arises in the preservation of undeformed crystals and islands of the original coarse-grained pegmatites in the gneiss.

Sillimanite rarely occurs in pegmatites and other igneous rocks, yet it is the most abundant mineral in part of the corundum-bearing rock at the Bear Trap deposit, and it is common in the finer-grained matrix at all three deposits. Muscovite, rather than sillimanite, is the dominant aluminous mineral in a few small lenses of the corundum-bearing rock. Biotite is a common minor component of the corundum rock, but it occurs only sparingly in the coarsely crystalline aggregates. In a few specimens, however, the large crystals are enclosed directly in clusters of large biotite flakes.

Heinrich $(1949$, p. 316) noted the local abundance of sillimanite and muscovite and concluded that these two minerals are "clearly later than the other minerals and have developed at their expense." $\mathrm{He}$ attributed their development to the action of solutions rich in aluminum which converted microcline to muscovite and biotite and microcline to sillimanite. His hypothesis fails to account for the preferred orientation of most of the sillimanite and muscovite in the gneissoid rock.

Thin sections show that muscovite is intergrown with corundum and feldspar in such a fashion as to suggest both simultaneous development of the minerals and replacement of feldspar and corundum by muscovite. Sillimanite and biotite are commonly intergrown, but this relation is more commonly observed in metamorphic rocks than in pegmatites altered by deuteric changes or hydrothermal replacement. Corundum partly altered to sillimanite has not been observed in thin sections, but skeletal crystals of corundum commonly appear to have grown across and to have surrounded pre-existing patches of subradial or contorted sillimanite. Sillimanite is generally absent from a very narrow zone immediately adjacent to the corundum, so that the two minerals are rarely in contact, although often in close proximity. (See figs. 12 and 13.) This relation suggests that corundum may have developed in part at the expense of sillimanite in a sillimanite-bearing metamorphic rock. The reciprocal relationship in the abundance of sillimanite and corundum in one series of samples (samples 11-26, pl. 6) supports the suggestion.

The hypothesis of igneous origin appears to be inadequate, and the similarity of the Montana deposits to African and Appalachian deposits, for which an igneous origin has been proposed, is more apparent than real. The hypothesis fails to disclose a mechanism for obtaining the requisite silica-deficient magma through desilication, 


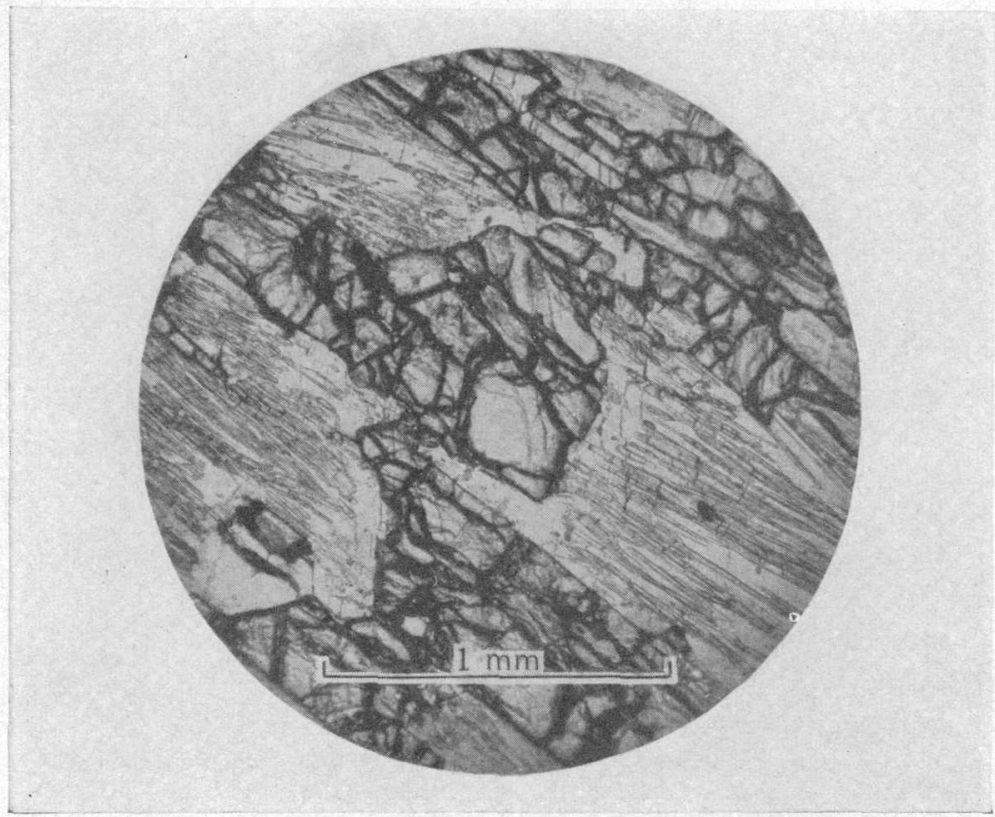

Figure 12.- Photomicrograph showing platy, skeletal erystals of corundum in corundumsillimanite gneiss from the Elk Creek corundum deposit. The corundum is characterized by prominent fractures and strong relief; sillimanite occurs as small elongate needles in clear perthite.

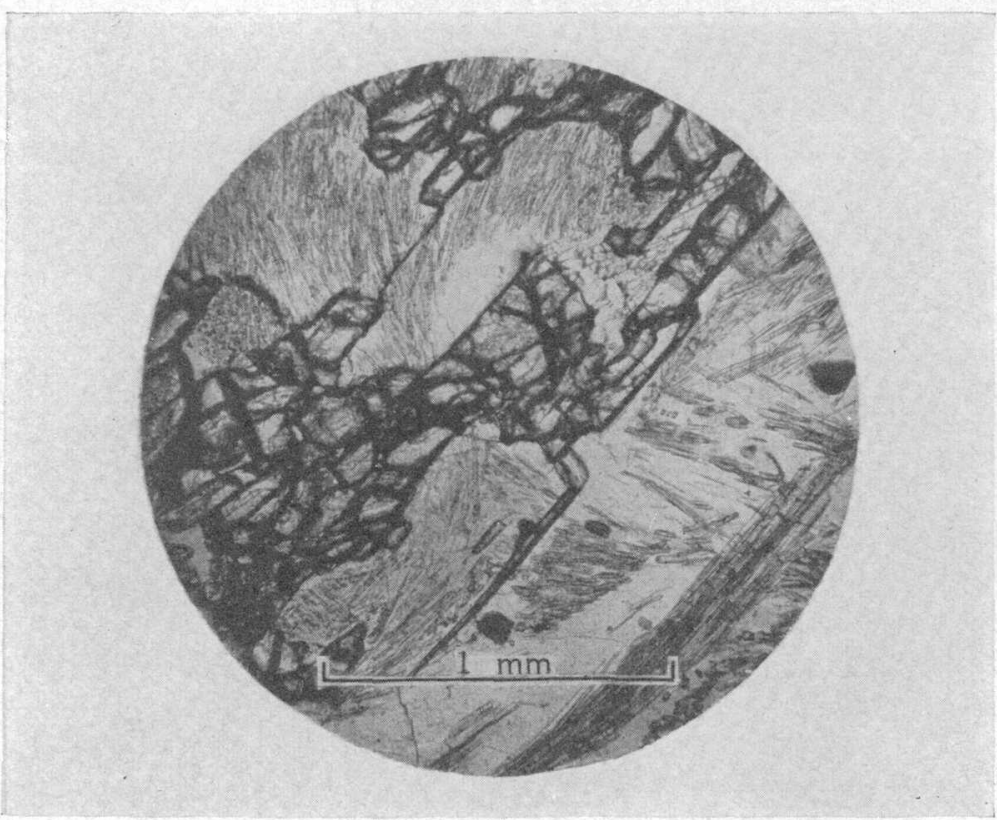

Figure 13.-- Photomicrograph of corundum erystals transecting subradial sillimanite in corundum-sillimanite gneiss from the Elk Creek corundum deposit. The minerals are the same as those in figure 12 ; corundum with dark margins and fractures, sillimanite in small needles, and clear perthite enclosing the sillimanite. 
it does not account for the gneissic fabric of the finer-grained parts of the rock or for the mineral relations, and it finds no support in the conformable contacts and lack of wallrock inclusions in the tabular corundum-bearing bodies.

\section{HYPOTHESIS OF HYDROTHERMAL ORIGIN}

The hydrothermal processes suggested by Larsen to account forthe plumasite and albitite dikes in ultrabasic rocks, like the pegmatite desilication hypothesis of DuToit, Hall, and others, can hardly account for certain characteristics of the Montana deposits, and some of the objections to igneous origin presented above apply also to a hydrothermal hypothesis. The metamorphic fabric of part of the rock and the absence of discordant relations with wallrocks are as little to be expected in hydrothermal veins or replacement bodies as in igneous rocks, and a preponderance of sillimanite like that in part of the Montana corundum rock is unknown in hydrothermal deposits. Sillimanite, however, does occur in small quantity in the alteration border zones of some African deposits and kyanite is a major constituent of one Transvaal corundum-bearing dike or vein.

If corundum developed in these deposits as a consequence of the action of hydrothermal fluids, the alumina may have been supplied from either (or both) of two sources; it could have been brought in by the solutions or it could have been obtained from rocks through which the solutions passed or upon which they acted, much as limestone supplies calcium for the formation of lime silicates in contact metamorphism. The possibility that the corundum-bearing rocks were derived from pre-existing aluminous layers in the metamorphic complex by hydrothermal contact metamorphism or by metasomatic processes accompanying extreme regional metamorphism will be considered further in the section dealing with the hypothesis of metamorphic origin.

The alumina-rich solutions postulated by Larsen as the parent of plumasite and albitite bodies formed such rocks only in the presence of silica-deficient, peridotitic wallrocks, and the solutions were presumably related genetically to the ultrabasic rocks. The Montana deposits do not occur in ultrabasic rocks, and the possibility that they formed from solutions supplied by an ultrabasic magma appears unlikely, despite the occurrence of peridotite at the Bear Trap corundum deposit and elsewhere in the region. The peridotite at the Bear Trap deposit is a small dike; it is not in contact with the corundum-bearing rock; and with the exception of vermiculite, the minerals observed in association with the dike are unlike those of the corundum deposits. No ultrabasic dikes occur in the vicinity of the Elk Creek and Bozeman 
corundum deposits, and no corundum has been found near other ultrabasic dikes in the region.

If the alumina is assumed to have been supplied by the hydrothermal solutions, its ultimate source is difficult to postulate. The country rock is quartz-bearing, therefore desilication of hydrothermal solutions is no more likely than desilication of an invading pegmatite magma. The solutions must have been so rich in alumina with respect to silica that they could travel through quartz-bearing rocks, locally react with them to create a vermiculite-rich border zone, and finally deposit corundum-bearing veins or form corundum-bearing replacement deposits. It is questionable that such solutions could have existed.

HYPOTHESIS OF ORIGIN BY METAMORPHISM AND METASOMATISM OF ALUMINARICH SEDIMENTARY ROCKS

The metanorphic complex in which the corundum deposits occur was unquestionably derived from a thick series of clastic sedimentary rocks and limestones which were converted by regional metamorphism to alternating layers of gneiss, quartzite, and marble. Marble does not occur in the vicinity of the corundum deposits, but it is abundant in the metamorphic rocks to the northeast and southwest. Foliation of the gneiss is generally parallel to beds of quartzite and therefore parallel to the original bedding of the sedimentary rocks.

Pyroclastic rocks, lava flows of basalt and rhyolite, and sills or larger intrusives of igneous rocks may have been associated with the sedimentary rocks and may have been metamorphosed to form some of the layers of hornblende gneiss and granite gneiss. But there is little direct evidence to justify the assumption that igneous rocks were extensively interlayered with the original sedimentary rocks or injected into them. On the contrary, the hornblende-rich layers grade into other varieties of gneiss; they are intimately interlayered with thin quartzite beds in many places, and both they and the granitelike gneisses lack the uniformity of composition generally found in igneous bodies.

The metamorphism to which the rocks of the so-called Pony series were subjected in this area was intense. No evidence of original grain size can be found in the coarsely crystalline quartzite. Not uncommonly the gneiss is coarsely crystalline, and feldspar crystals several centimeters in length scattered through light-colored gneiss were observed at several places, notably about 1 mile northeast of Anceny, where the rock resembles a porphyritic granite. Sillimanite, a mineral considered indicative of intense metamorphism, is abundant in the corundum deposits. 
The sedimentary origin of the associated metamorphic rocks and the metamorphic fabric of part of the corundum-bearing rock suggests that the corundum deposits were originally sedimentary concentrations of alumina that were also subjected to regional metamorphism. Comparable concentrations of alumina are found in unmetamorphosed sedimentary rocks as deposits of relatively pure clay, laterite, and bauxite. The distribution of the corundum-bearing bodies in narrow belts in the gneiss is accounted for by the hypothesis of sedimentary origin. Alumina-rich sedimentary material is assumed to have been transported and deposited as widespread but discontinuous layers at one or more restricted horizons in a series of clastic sedimentary rocks. More or less contemporaneous deposition of all of the corundum deposits is indicated by the similarity of the enclosing hornblende gneiss and quartzite and the distribution of the occurrences. The tabular to lenticular form of the deposits, their concordance with the bedding of the enclosing rocks, and the absence of inclusions are certainly more characteristic of sedimentary beds and lenses than of hydrothermal deposits or igneous intrusives.

The chemical analysis of the corundum-bearing rock from the Elk Creek deposit and. Roger's' calculated composition of a corundumrock sample from the Bozeman deposit are repeated in table 3 for comparison with the composition of selected clay materials, clay deposits, and laterite. Some of the corundum-bearing rock at the Bear 'Trap deposit contains as much as 90 percent sillimanite, and other parts of it are made up almost exclusively of muscovite; therefore the ideal composition of sillimanite and of muscovite are given in the table to indicate limits approached by the range of composition of the corundum-sillimanite gneiss. Analysis I is probably most nearly representative of the average corundum-bearing layers; it indicates a composition which might be duplicated in sediments by an impure potash-rich clay (illite) or a sericitic mud containing iron oxides and minor quantities of other impurities. Most sedimentary clays are mixtures of illite and kaolinite, and Grim (1942, p. 261) states that illite is the dominant clay mineral of shales, till, and loess, so far as is known. The iron content of the corundum-bearing rock is lower than that of most laterites, although laterites derived from granites and similar rocks may contain even less. The alumina content is not as great as that of most of the clays, laterites, and bauxite deposits investigated as potential sources of aluminum. Sediments that are rich in alumina almost always contain an unusual amount of titanium as well, and an abundance of titanium in the corundum deposits is indicated by the constant association of corundum and rutile. Part of the alkalis in the rock may have been introduced during metamorphism. 
TABLE 3.-Chemical composition of the Montana corundum-bearing roclis and selected aluminous minerals and rocks

\begin{tabular}{|c|c|c|c|c|c|c|c|c|c|c|}
\hline & I & II & III & IV & $\mathrm{v}$ & VI & VII & VIII & $1 x$ & $\mathrm{x}$ \\
\hline $\mathrm{SiO}_{2}$. & 46.98 & 44.1 & 36.8 & 45. 2 & 44.01 & 50.10 & 44.81 & 6. 45 & 46.2 & 41.1 \\
\hline $\mathrm{Al}_{2} \mathrm{O}_{3} \ldots$ & 3555 & 43.7 & 63.2 & 38.5 & 26.81 & 25.12 & 37.82 & 39.85 & 35.7 & 31.5 \\
\hline $\mathrm{TiO}_{2} \ldots$ & 35.50 & $\cdots . .$. & ... & .... & .64 & .50 & .37 & 1.53 & ... & \\
\hline $\mathrm{Fe}_{2} \mathrm{O}_{3}$ & & .3 & & & 11.99 & 5. 12 & .92 & 31.35 & .1 & 13.9 \\
\hline $\mathrm{FeO}$ & 6.14 & .9 & & & -....... & 1.52 & & & & \\
\hline $\mathrm{MnO}$. & .13 & - & & & & $\ldots$ & .00 & & $\ldots$. & .14 \\
\hline $\mathrm{CaO} \ldots$ & .94 & $\ldots$ & - & ....... & .11 & .35 & .43 & $\ldots$ & .37 & .09 \\
\hline $\mathrm{MgO} \ldots . . .$. & 1.72 & .7 & & $\ldots$ & 2.43 & 3.93 & .35 & .36 & .21 & .14 \\
\hline $\mathrm{K}_{2} \mathrm{O} \ldots \ldots$ & 4.26 & 5.0 & $\ldots$ & 11.8 & 4. 78 & 6.93 & $\ldots . .$. & $\cdots$ & .03 & .00 \\
\hline $\mathrm{Na}_{2} \mathrm{O} \ldots \ldots \ldots . . .$. & 2.99 & 4.3 & $\ldots$ & $\ldots$ & .07 & .05 & $\ldots$ & -. & .67 & .06 \\
\hline $\mathrm{ZrO}_{2} \ldots$ & ...... & .5 & 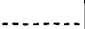 & - & - & $\ldots . .$. & $\ldots$ & & .. & $\cdots$ \\
\hline $\mathrm{P}_{2} \mathrm{O}_{5}$ & ...... & $\ldots$ & & & $\ldots$ & $\ldots .$. & $\cdots$ & & $\ldots$ & ...... \\
\hline Ignition Ioss.... & .78 & $\ldots$ & & & 9.19 & 6.82 & $\ldots$ & 20.46 & 16.8 & 12.6 \\
\hline \multirow[t]{2}{*}{$\mathrm{H}_{2} \mathrm{O}$} & (n....... & .2 & & 4.5 & - nent & $\cdots+$ & 15. 37 & $\ldots$ & n.... & (n........ \\
\hline & 99.49 & 99.7 & 100.0 & 100.0 & 100.03 & 100.44 & 100.07 & 100.00 & 100.1 & 99.6 \\
\hline
\end{tabular}

I. Corundum-bearing rock, Elk Creek deposit, Gallatin County, Mont. Analysis by Glen Edgington, U. S. Dept. Agr., Bur. Entomology and Plant Quarantine.

II. Corundum-bearing rock, Bozeman deposit, Gallatin County, Mont. Composition calculated from mineral content. Reported by A. F. Rogers in Jour. Gcology, vol. 19, p. 750.

11I. Ideal composition of sillimanite, $\mathrm{Al}_{2} \mathrm{SiO}_{5}$, the only major constituent of some parts of the corundumbearing rock at the Bear Trap deposit, Madison County, Mont..

IV. Ideal composition of muscovite, $\mathrm{H}_{2} \mathrm{KAl}_{3} \mathrm{Si}_{3} \mathrm{O}_{12}$. Muscovite, like sillimanite, is the predominant mineral of a minor part of the corundum-bearing rock at the Bear Trap deposit, Madison County, Mont. Sericite, with essentially the same composition, is reported to be abundant in some impure clays and shales.

V. Fine colloid fraction (illite), Pennsylvanian shale, Menard County, Ill. Analysis made under supervision of $O$. W. Rees, Reported by Grim, Bray, and Bradley in Am. Mineralogist, vol. 22, p. 823.

VI. Fine colloid fraction (illite), Maquokata (Ordovician) shale, Calhoun County, Ill. Analysis made under supervision of $\mathrm{O}$. W. Rees. Reported by Grim, Bray, and Bradley in Am. Mineralogist, vol. 22, p. 823.

VIr. Kaolinite associated with arkosic sand, Mexia, Tex. Analyzed by F. A. Conyer. Reported by Ross and Kerr in U. S. Geol. Survey Prof. Paper 165-E, p. 163.

VIII. Laterite near Jones Butte, Amador County, Calif. Analysis by Curtis and Tompkins, Ltd., San Francisco. Reported by T. F. Bates in Creol. Soc. A merica Bull. 56, p. 15.

IX. Very pure transported clay, Troy, Idaho. Analyzed by R. V. Lundquist. Reported by Tullis and Lancy in Econ. Geology, vol. 28, p. 493.

$\mathrm{X}$. Partly decomposed biotite from highly altered biotite schist, Joel, Idaho. Analyzed by R. V. Lundquist. Reported by 'Tullis and Laney in Econ. Geology, vol. 23, p. 488.

The deposition and preservation of thin beds ind small lenses of a relatively pure clay in a series of clastic sediments is remarkable, but beds of clay even more highly aluminous are reported to occur in unmetamorphosed clastic sedimentary rocks at a few localities. It is not surprising that beds and lenses of such unusual composition are restricted to a few horizons, possibly to a single horizon in the metamorphosed sedimentary rocks of the region. Contamination of the clay with sand and other impurities during deposition probably accounts for the wide range in composition observed in the corundumbearing rocks and closely related layers of sillimanite gneiss and feldspar-garnet-mica gneiss which contain little or no corundum. 
The association of the deposits with rocks that have undergone regional metamorphism suggests that they too may have been produced by essentially dynamothermal processes acting on aluminarich sedimentary beds. If the corundum-bearing rock were entirely of the finer grained gneissic matrix type, its origin by simple regional metamorphism would hardly be questioned. The finer grained rock commonly: contains an abundance of sillimanite, and it resembles sillimanite schists and gneisses produced by regional metamorphism of aluminous sedimentary rocks elsewhere. The presence of accessory corundum rather than quartz can be accounted for by assuming a high alumina content in the original sediment. The corundum-bearing layers are more restricted in extent than most sillimanite schists, but the form of the individual layers is not unlike that of the adjacent quartzite beds, which appear equally lenticular and discontinuous if examined in detail. (See pl. 5.)

But the pegmatitic texture of the coarse-grained corundum-perthite rock is markedly unlike that of most dynamothermally metamorphosed rocks. The coarsely crystalline material occurs as irregular patches, stringers and orbicules in the matrix of medium- to finegrained gneiss, and sillimanite is rare in the coarse corundum-perthite aggregates. The corundum in the coarse stringers and patches occurs chiefly in large barrel-shaped crystals, whereas that in the adjacent fine-grained sillimanite gneiss is chiefly in small platy crystals.

The absence of foliation or other directive fabric in the coarsely crystalline material suggests that it crystallized after deforming forces had subsided, whereas the enclosing sillimanite gneiss appears to have attained its fabric during the dynamic stages of regional metamorphism. Development of the stringers and orbicules of coarsely crystalline corundum-perthite rock therefore appears to have been a recrystallization and replacement process superimposed on the normal processes of regional metamorphism by which the sillimanitecorundum schist was formed. The large size of the crystals indicates relatively free movement of material in solution at elevated temperature. Had the recrystallization gone farther and destroyed completely the gneissic fabric of the matrix, the resulting body of coarsely crystalline rock might well be considered a pegmatite developed in place.

The partial conversion of sillimanite gneiss into coarse-textured corundum-perthite rock probably accompanied the development of local masses of strongly banded gneiss in the adjacent fine-grained metamorphosed county rock. Light and dark minerals were segregated and the texture of the gneiss was coarsened. Heated aqueous solutions undoubtedly facilitated the reconstitution of both the 
gneisses and the corundum-bearing rocks. Temperatures are assumed to have risen during the process of regional metamorphism to reach a culmination in the final stages as deforming forces subsided and as a subjacent batholith came into existence. The batholith, accompanied by swarms of pegmatites, rose into the overlying metamorphic rocks and drove before it heated solutions and hyperfusible components derived in part from the metamorphic rocks themselves. These conditions of elevated temperature and mobilized solutions are the environment suggested for the development of the coarse-grained corundum rock.

Eskola (Barth, Correns, and Eskola, 1939, pp. 264-267) and others have recognized two related phases of regional metamorphism in many regions. The first is marked by strong deformation and conse. quent development of preferred orientation of mineral grains in the rocks involved. The second phase, generally affecting only the more deeply buried portions of the deformed rocks, is a stage of essentially static thermal metamorphism, usually accompanied by the emplacement of batholiths, the development of migmatites, and possibly granitization. Metasomatism and transfer of material are conspicuous in this deep-seated or plutonic phase of regional metamorphism. Moyd suggested extreme metamorphic processes of this type to account for the banded nepheline syenites and associated corundumbearing rocks of Ontario. Metamorphism of the ancient sedimentary rocks associated with the corundum deposits in southwestern Montana was evidently not so extreme as that in Ontario and in other regions where extensive migmatites and igneous-appearing rocks have been developed, but the Montana rocks show ample evidence of the introduction of alkalis, especially soda, and of penetration by solutions or "mineralizers" that facilitated recrystalization and reaction.

The development of the corundum-perthite rock from sillimanite gneiss was undoubtedly encouraged by the introduction of soda or other alkalis, as illustrated by the following reaction :

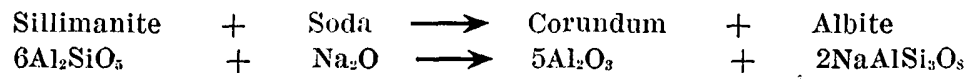

The alkali content of aluminous sedimentary rocks is generally less than that of corundum-bearing crystalline rocks. (See tables 2 and 3.) This relation suggests that in general the conversion of a sedimentary rock to a corundum-bearing rock requires or involves enrichment of the rock in alkalis. If the sillimanite-bearing rock contains free quartz, or if silica and alkali are introduced simultaneously, more feldspar and less corundum, or possibly no corundum will result. For example, where several small quartz-bearing pegmatite stringers inter- 
sect the main corundum-bearing lens in the Elk Creek deposit, they merge with the coarse-grained corundum-bearing rock to form areas of light-colored, coarse-grained perthite rock that contains. neither the quartz of the pegmatite nor the corundum and sillimanite of the corundum-bearing rock.

Sillimanite rarely occurs in igneous rocks and pegmatites; therefore it appears to be unstable in the igneous environment and under high-temperature hydrothermal conditions of the type that accompany pegmatite formation. Hydrothermal contact metamorphism also leads to the destruction of sillimanite and the development of muscovite, feldspar, corundum, and other minerals in its place. At least under some conditions both corundum and quartz develop in the same rock from contact metamorphic destruction of sillimanite as noted by Ball in Colorado. Further evidence of the instability of sillimanite during hydrothermal metamorphism is found in the sillimanite gneiss near the Elk Creek corundum deposit in sec. 28, T. 3 S., R. 3 E. (See p. 72). The final metamorphic changes in this rock involved introduction of soda and silica as indicated by partial conversion of andesine to sodic oligoclase; marginal replacement of feldspar by myrmekitic quartz; development of irregular stringers and patches of quartz and feldspar in subgraphic intergrowth; and formation of reaction borders of fine-grained mica, feldspar, and other minerals separating sillimanite from the quartz and the more sodic plagioclase.

Some of the corundum-bearing rock consists almost exclusively of muscovite, and from such rocks corundum and feldspar may form during metamorphism without the addition of alkalis:

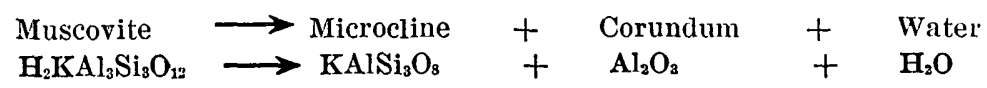

The occurrence of aureoles of microline surrounding corundum crystals in the muscovite-rich rock is in agreement with the proposed reaction.

The vermiculite-rich borders or alteration zones which enclose corundum-bearing dikes in South Africa and in the southern Appalachians were thought by DuToit, Hall, and others to have been formed by reaction between pegmatites and ultrabasic wallrocks. Larsen pointed out that the minerals of the alteration zone are chiefly hydrothermal, not igneous, and the quantitative chemical relations are such that the vermiculite zone could not have developed by simple reaction, but that hydrothermal solutions must have removed entirely some materials and added others The friable, vermiculite-rich border zone that encloses the corundum-bearing lenses in Montana is similar in some respect to those in the other regions, but it is interpreted as a reaction zone between adjacent bodies of chemically and mineralogi- 
cally dissimilar metamorphic rocks, rather than a product of igneous reaction or of through-going hydrothermal solutions of the sort postulated by Larsen. This interpretation requires that part of the material from the margin of a corundum-bearing lens and from the adjacent hornblende gneiss be dissolved, transferred for distances of at least a few inches and recombined to form new minerals in a rock of intermediate composition. Widespread introduction of solutions during the final stages of regional metamorphism has already been postulated, but the solutions are assumed to have been limited in quantity and incapable of adding or subtracting quantities of material large enough to change greatly the bulk composition of a body of rock. Therefore the reaction zone between the layers should have approximately the same composition as some mixture of the two parent rocks. Analyses of the vermiculite zone and the adjacent hornblende gneiss and corumdum-bearing rock from the Elk Creek deposit are presented together for comparison in table 4. It is evident that the vermiculite zone contains an excess of soda, and this is readily explained, for small pegmatitic stringers of quartz and sodic feldspar are more numerous in the vermiculite zone than in the adjacent hornblende gneiss, and soda and silica may safely be assumed to have been introduced by solutions which facilitated reaction and recrystallization. Column V of the table is the calculated composition of a hypothetical reaction zone formed by combining hornblende gneiss and corundum-bearing rock (columns I and II) in a $3: 1$ ratio and adding 2 percent each of soda and water and 4 percent silica. The calculated percentage of lime is greater than that found in the vermiculite zone, but otherwise the calculated composition is remarkably similar to analyses of the actual rock (columns III and IV). The quantitative chemical relations of the rocks thus do not seem to be in serious conflict with the postulated mode of origin of the vermiculite zone. The local absence of the reaction border, like the local absence of strongly banded gneiss is attributed to the failure of solutions to permeate equally all parts of the metamorphic rocks.

The hypothesis of combined sedimentary and metamorphic origin of the corundum deposits appears more nearly adequate than an igneous or hydrothermal hypothesis, for it utilizes a reasonable mechanism for concentrating alumina; it accounts for the form and distribution of the deposits, and it is compatible with the observed variations in texture and in composition. Consideration of this hypothesis leads to the suggestion that future search for corundum deposits in the region should be concentrated upon areas of quartzitebearing gneiss and should begin with extension of the known deposits along their strike insofar as possible. 
TaBre 4.-Composition of the corundum-bearing rock, the associated vermiculiterich border zone, and the adjacent hornblende gneiss

\begin{tabular}{|c|c|c|c|c|c|}
\hline & $\begin{array}{l}\text { I } \\
\text { Corun- } \\
\text { dum- } \\
\text { bearing } \\
\text { rock }\end{array}$ & $\begin{array}{l}\text { II } \\
\text { Horn- } \\
\text { blende } \\
\text { gneiss }\end{array}$ & $\begin{array}{c}\text { III } \\
\text { Vermicu- } \\
\text { lite-rich } \\
\text { border }\end{array}$ & $\begin{array}{c}\text { IV } \\
\text { Composite } \\
\text { sample of } \\
\text { border } \\
\text { zone }\end{array}$ & $\begin{array}{c}\mathrm{V} \\
\text { Hypothet- } \\
\text { ical combi- } \\
\text { nation of } \\
\text { I and II }\end{array}$ \\
\hline $\mathrm{SiO}_{2} \ldots \ldots$ & 46.98 & 52.97 & 52.26 & 51. 32 & $51 . .52$ \\
\hline $\mathrm{Al}_{2} \mathrm{O}_{3}, \mathrm{TiO}_{2}$, etc $\ldots$ & 35.55 & 15.61 & 20.63 & 19.55 & 19. 01 \\
\hline Total iron reported as $\mathrm{Fe}_{2} \mathrm{O}_{3} \ldots \ldots \ldots$ & 6.14 & 15.45 & 13. 25 & 14. 98 & 12. 10 \\
\hline $\mathrm{CaO}$ & .94 & 7. 49 & 2.39 & 2.80 & 5. 40 \\
\hline 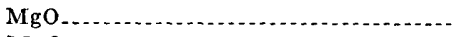 & 1. 72 & 4. 19 & 3. 35 & 3.54 & 3.30 \\
\hline $\mathrm{MnO}$ & .13 & .30 & .23 & .25 & .24 \\
\hline $\mathrm{Na}_{2} \mathrm{O}$ & 2. 99 & 2.61 & 4. 53 & 4. 00 & 4. 49 \\
\hline $\mathrm{K}_{2} \mathrm{O} \ldots \ldots$ & 4. 26 & .59 & 1.15 & 1.34 & 1. 39 \\
\hline \multirow[t]{2}{*}{ Ignition loss } & .78 & .52 & 2,35 & 2.58 & 2.55 \\
\hline & 99.49 & 99.73 & 100. 14 & 100.36 & 100.00 \\
\hline
\end{tabular}

\section{REFERENCES CITED}

Anderson, H. V., and Chesley, K. G., 1931, X-ray analysis of slate: Am. Jour. Sci., 5th ser., vol. 22.

Ball, S. H., 1908, General geology, in Spurr, J. E., and Garrey, G. H., Economic geology of the Georgetown quadrangle (together with the Empire district) :

U. S. Geol. Survey Prof. Paper 63.

—_ 1937, Gem stones: U. S. Bur. Mines Minerals Yearbook, 1937.

1938, Gem stones: U. S. Bur. Mines Minerals Yearbook, 1938.

1939, Gem stones: U. S. Bur. Mines Mineral Yearbook, 1939.

1940, Gem stones: U. S. Bur. Mines Minerals Yearbook, 1940.

1941, Gem stones: U. S. Bur. Mines Minerals Yearbook, a review of 1940.

1943, Gem stones: U. S. Bur. Mines Minerals Yearbook, 194.1.

1943a, Gem stones: U. S. Bur. Mines Minerals Yearbook, 1942.

—_ 1945, Gem stones: U. S. Bur. Mines Minerals Yearbook, 1943.

1946, Gem stones; U. S. Bur. Mines Minerals Yearbook, 1944.

Barlow, A. E., 1915, Corundum, its occurrence, distribution, exploitation, and uses: Canada Dept. Mines Geol. Survey Mem. 57.

Barth, T. F. W., Correns, C. W., and Eskola, P., 1939, Die Entstehung der Gesteine, Berlin, Springer Publishing Co.

Clabaugh, S. E., 1950, Pegmatites of Montana : Econ. Geology, vol 45, no. 3.

Clabaugh, S. E., and Armstrong, F. C., 1951, Corundum deposits of Gallatin and Madison Counties, Mont.: U. S. Geol. Survey Bull. 969-B.

Du'Toit, A. L., 1918, Plumasite (corundum-aplite) and titaniferous magnetite rocks from Natal: Geol. Soc. South Africa Trans. 21.

Finlay, G. I., 1907, On an occurrence of corundum and dumortierite in Colorado: Jour. Geol., vol. 15, no. 5.

Freeman, O. W., 1915, The sapphire mines of Yogo, Mont.: Mining and Scientific Press, vol. 110.

Grim, R. E., 1942, Modern concepts of clay materials: Jour. Geology, vol. 50, no. 3.

Hadley, J. B., 1949, Preliminary report on corundum deposits in the Buck Creek peridotite, Clay County, N. C. : U. S. Geol. Survey Bull. 94S-E.

Hail, A. L., 1920, Corundum in northern and eastern Transvaal: Union of South Africa Geol. Survey Mem. 15. 
Harstead, A. J., 1926, Montana sapphires : Rocks and Minerals, vol. 1, no. 2. Heinrich, E. W', 1949, Pegmatites of Montana: Econ. Geology, vol. 44, no. 4. 1950, Syenitic corundum pegmatites near Bozeman, Mont. : Econ. Geology, vol. 45 , no. 4 .

- 1950a, The Camp Creek corundum deposit near Dillon, Beaverhead County, Mont. : Montana Bur. Mines and Geology Misc. Contr., no. 11.

Heinrich, E. W., and Griffitts, W. R., 1947, Turret corundum deposits, Chaffee County, Colo. (Abstract): Geol. Soc. America Bull., vol. 58, pt. 2, no. 12. Johamnsen, Albert, 1938, A descriptive petrography of the igneous rocks, 1st ed., vol. 4, pt. 1, Univ. Chicago Press.

- 1939, A descriptive petrography of the igneous rocks, 2 d ed., vol. 1, Univ. Chicago Press.

Kemp, J. F., 1891, The basic dikes occurring outside of the syenite areas of Arkansas: Arkansas Geol. Survey Ánn. Rept. for 1890, vol. 2.

Kunz, G. F., 1.883, U. S. Geol. Survey Mineral Resources U. S., 1882.

1890 , Gems and precious stones of North America, New York, The Scientific Publishing Co.

— 1.893, Precious stones: U. S. Geol. Survey Mineral Resources U. S., 1891.

1893a, Precious stones: The Mineral Industry, 1892, vol. 1.

- 1.894, Precious stones: U. S. Geol. Survey Mineral Resources U. S., 1893.

1895, Precious stones: U. S. Geol. Survey 16th Ann. Rept., pt. 4.

- 1896, Precious stones: U. S. Geol. Survey 17th Ann. Rept., pt. 3.

- 1897, On the sapphires from Montana, with special reference to those

from Yogo Gulch in Fergus County: Am. Jour. Sci., 4th ser., vol. 4.

- 1.897a, Precious stones: U. S. Geol. Survey 18th Ann. Rept., pt. 5.

- 1899, Precious stones: U. S. Geol. Survey 20th Ann. Rept., pt. 6.

1901, Precious stones: U. S. Geol. Survey Mineral Resources U. S., 1900.

- 1901.a, Precious stones: U. S. Geol. Survey 21st Ann. Rept., pt. 6 (con-

tinued).

1.902, Precious stones: U. S. Geol. Survey Mineral Resources U. S., 1901.

1904, Precious stones: U. S. Geol. Survey Mineral Resources U. S., 1902.

1905, U. S. Geol. Survey Mineral Resources U. S., 1904.

__ 1911, Precious stones: The Mineral Industry, 1910, vol. 19.

1.912, Precious stones: The Mineral Industry, 1911, vol. 20.

_1. 1913, Precious stones: The Mineral Industry, 1912, vol. 21.

1921, Precious stones: The Mineral Industry, 1920, vol. 29.

1924, Precious stones: The Mineral Industry, 1923, vol. 32.

1.928, Precious stones: The Mineral Industry, 1927, vol. 36.

1.930, Precious and semiprecious stones: The Mineral Industry, 1929, vol. 38 .

Iagorio, A., 1895, Pyrogener Korund, dessen Verbreiten und Herkunst: Zeitschr. Kristallographie, vol. 24.

Larsen, E. S., Jr., 1928, A hydrothermal origin of corundum and albitite bodies: Econ. Geology, vol. 23, no. 4.

Lawson, A. C., 1904, Plumasite, an oligoclase-corundum rock near Spanish Peak, Calif.: Bull. Dept. Geol. Univ. California, vol. 3, no. S, pp 219-229.

Montana Bureau of Agriculture, Labor, and Industry, 1902, 8th Ann. Rept.

Morozewicz, Josef, 1895, Ueber die Kunstliche Darstellung von Spinel und Korund aus Silicatschmelzen: Zeitschr. Kristallographie, vol. 24.

Moyd, Louis, 1946, Petrology of the nepheline and corundum-bearing rocks of southeastern Ontario (Abstract) : Am. Mineralogist, vol. 31. 
Pardee, J. T., and Schrader, F. C., 1933 Metalliferous deposits of the greater Helena mining region, Montana: U. S. Geol. Survey Bull. 842.

Peale, A. C., 1896, U. S. Geol. Survey Geol. Atlas; Three Forks, Mont. folio (nø. 24).

Pirsson, L. V., 1897, On the corundum-bearing rock from Yogo Gulch, Mont. : Am. Jour. Sci., 4th ser., vol. 4 .

1900, A report on the petrography of the igneous rocks of the district, in

Weed, W. H., Petrography of the igneous rocks of the Little Belt Mountains,

Mont.: U. S. Geol. Survey 20th Ann. Rept., pt. 3.

Pratt, J. H., 1902, Abrasive materials: U. S. Geol. Survey Mineral Resources U. S., 1902.

1906, Corundum and its occurrence in the United States: U. S. Geol. Survey Bull. 269.

Pratt, .J. H., and Lewis, J. V., 1905, Corundum and the peridotites of western North Carolina: North Carolina Geol. Survey Rept., vol. 1.

Rogers, A. F., 1911, On corundum-Syenite (uralose) from Montana: Jour. Geology, vol. 19, no. 8.

1912, Baddeleyite from Montana: Am. Jour. Sci., 4th ser., vol. 33.

Smith, J. L. 1873, Notes on the corundum of North Carolina, Georgia, and Montana, with a description of the gem variety of the corundum from these localities: Am. Jour. Sci., 3d ser., vol. 6.

Sterrett, D. B., 1907, Precious stones: U. S. Geol. Survey Mineral Resources U. S., 1906.

- 1908, Precious stones: U. S. Geol. Survey Mineral Resources U. S., 1907, pt. 2.

1909, U. S. Geol. Survey Mineral Resources, 190\$, pt. 2.

1911, U. S. Geol. Survey Mineral Resources, 1909, pt. 2.

1911a, Gems and precious stones: U. S. Geol. Survey Mineral Resources

U. S., 1910, pt. 2.

1912, Gems and precious stones: U. S. Geol. Survey Mineral Resources

U. S., 1911, pt. 2.

1913, Gems and precious stones: U. S. Geol. Survey Mineral Resources

U. S., 1912, pt. 2.

- 1916, U. S. Geol. Survey Mineral Resources, 1914, pt. 2.

Stoddard, B. H., 1922, Gems and precious stones: U. S. Geol. Survey Mineral

Resources U. S., 1919, pt. 2.

_ـ 1923, U. S. Geol. Survey Mineral Resources U. S. 1920, pt. 2.

1924, U. S. Geol. Survey Mineral Resources U. S., 1921, pt. 2.

Struthers, John, and Fisher, Henry, 1903, Gems and precious stones: The Mineral Industry, 1902, vol. 11.

Tansley, Wilfred, and Schafer, P. A., June 1933, in Tansley, Schafer, and Hart, A geological reconnaissance of the Tobacco Root Mountains, Madison County, Mont.: Montana Bur. Mines and Geology Mem. 9.

Weed, W. H., 1899, U. S. Geol. Survey Geol. Atlas, Little Belt Mountains folio (no. 56).

- 1900, Geology of the Little Belt Mountains, Mont.: U. S. Geol. Survey 20th Ann. Rept., pt. 3.

- 1902, Montana sapphires: The Mineral Industry, 1901, vol. 10.

Winchell, A. N., 1914, Mining districts of the Dillon quadrangle, Mont., and adjacent areas: U. S. Geol. Survey Bull. 574. 


\section{INDEX}

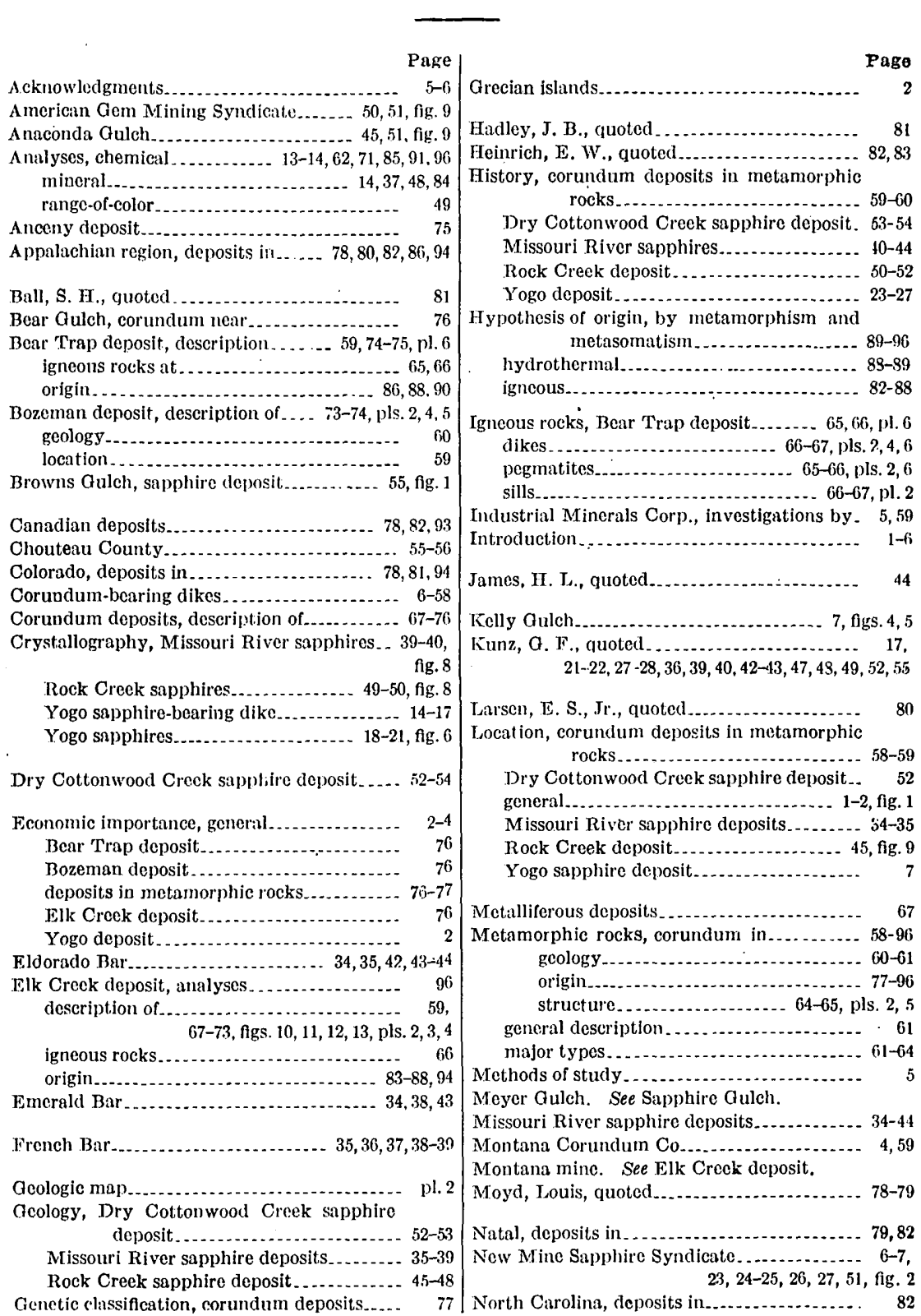


Page

Origin of corundum, examples in other regions_ 78-81 in dikes . . . . . $56-58$

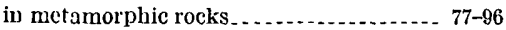
in sot:thwestern Montana. . . . . . . . . . . 82-96 sce also Hypothesis of origin.

Origin of sapphires, at French Bar.

Pirsson, L. V., quoted. 58

Placer deposits, associated with corundum

bearing dike................... 6-58

10,13

Pole Creek. ................ $\ldots$ 54-55, 76, pl. 2

Pratt, J. H., quoted.... $36,47,55$

Production, corundum deposits in metamorphic rocks. .............. 59-60

Dry Cottonwood Creek sapphire deposit.- 53-54

Missouri River sapphires................. 42-44

Rock Creek deposit . . . . . . . . 5 . 50-52

Yogo deposit..................... 31-33, table 1

Purpose of study

Quartz Gulch, sapphires at.............. 54, fig. 1

Recent investigations..................... 4-5

References............. 96-98

Rock Creek sapphire deposit, geology ......... 45-48

history and production.............. . . 50-52

location. . .

mineral analysis. . .................. 48

sapphires.

range-of-color analysis............... 49

Ruby Bar. See French Bar.

Sapphire Gulch. $45,47,51$

Sapphires, Dry Cottonwood Creek deposits..

French Bar 58

Missouri River deposit $39-40$, fig. 8
Sapphires-Continued

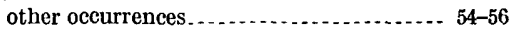

Rock Creek deposit. . . . . . . . . . . . 48-50

Yogo deposit.............. 2-4, 6-34, fig. 1, pl. 1 Sapphires in placer depcsits, associated minerals........ 38-39

Sillimanite, occurrence of .................. 76 $86-88,89,92,94$, figs, 12,13

Smith, J. L., quoted .... . . . . . . . . . . . . . . . . 40-42

South Africa, deposits in. ...2, 78, 79, 80, 82, 86, 88, 94

Sterrett, D. B., quoted . . ......... 12, 17, 25 $28,30,30-31,43,45-47,50,51,52,53,54$

Transvaal, deposits in . . . . . . . . . . 79-80, 82, 88

Turkey, deposits in ........................

Types of deposits......................... 1-2

Weed, W. H., quoted ........... 10, 11, 17, 4 :

Yogo Gulch............... 7, 9, 23, 25, 78, figs. 4, 5

Yogo sapphire deposit, general..... 2-4, fig. 1, pl. 1 geologic setting.................. $7-10$ history . ........................ 23-27

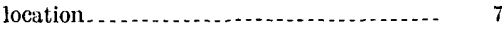

longitudinal section ... . . . . . . . . . . . . . . . . fig. 7

production methods.................. 27-31

reserves.................... 34

sapphire-bearing dike.... 7-10, 11-17, figs. $3,4,5$

sapphires, abundance................. 17-18

coating on

color

distribution .......................... 17

fracture................................ 21

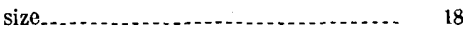

specific gravity .....................

value... 